\title{
Rochas intrusivas na Formação Castelo dos Sonhos, Cráton Amazônico: petrografia, geocronologia, geoquímica e implicações para as idades de sedimentação e da mineralização no depósito aurífero Castelo de Sonhos

\author{
Intrusive rocks in the Castelo dos Sonhos Formation, Amazon Craton: petrography, \\ geochronology, geochemistry and implications for sedimentation and mineralization \\ ages in the Castelo de Sonhos gold deposit
}

\author{
Joana D'Arc da Silva Queiroz', Evandro Luiz Klein", Joseneusa Brilhante Rodrigues" \\ Universidade Federal do Pará. Belém, Pará, Brasil \\ "CPRM/Serviço Geológico do Brasil, Divisão de Geologia Econômica. Belém, Pará, Brasil
}

\begin{abstract}
Resumo: A Formação Castelo dos Sonhos (FCS) localiza-se próximo ao limite entre os domínios Tapajós e Iriri-Xingu, na porção sudoeste do Pará. Trata-se de uma sequência metassedimentar siliciclástica ( < 2080 Ma), que hospeda o depósito aurífero tipo paleoplacer modificado Castelo de Sonhos. A FCS foi intrudida por um dacito porfirítico, que revelou idade de cristalização de $2011 \pm 6 \mathrm{Ma}$ (U-Pb LA-ICP-MS em zircão), e por um biotita granodiorito com idade de cristalização de $1976 \pm 7 \mathrm{Ma}(\mathrm{U}-\mathrm{Pb}$ SHRIMP em zircão). As idades obtidas permitem relacionar a gênese dessas rochas a eventos magmáticos distintos, que encontram possíveis correspondentes temporais no Domínio Tapajós - no Complexo Cuiú-Cuiú (2033-2005 Ma), na Formação Comandante Arara (2020-2012 Ma) e na Suíte Intrusiva Creporizão (1998$1957 \mathrm{Ma}$ ). Contudo, as rochas estudadas não mostraram padrões geoquímicos diretamente correspondentes às unidades destacadas. Ainda assim, o fato de rochas temporalmente relacionadas a unidades do Domínio Tapajós terem intrudido a FCS pode ser considerado uma evidência de relação temporal, espacial e provavelmente estratigráfica desta formação com aquele domínio. Os dados geocronológicos permitiram ainda que fosse estimada em $2011 \pm 6$ Ma a idade mínima da sedimentação da FCS e, por conseguinte, da mineralização aurífera singenética nela hospedada.
\end{abstract}

Palavras-chave: Cráton Amazônico. Formação Castelo dos Sonhos. Geocronologia U-Pb. Geoquímica. Petrografia. Rochas intrusivas.

\begin{abstract}
Castelo dos Sonhos Formation (CSF) is located next to the boundary between Tapajós and Iriri-Xingu tectonic domains, in southwestern Pará State. It is a siliciclastic metasedimentary sequence $(<2080 \mathrm{Ma})$, which hosts Castelo de Sonhos modified paleoplacer gold deposit. CSF was intruded by a dacite porphyry, which yielded a zircon U-Pb (LA-ICP-MS) crystallization age of $2011 \pm 6 \mathrm{Ma}$, and by a biotite granodiorite that yielded a zircon U-Pb (SHRIMP) crystallization age of $1976 \pm 7$ $\mathrm{Ma}$. The crystallization ages of these rocks associate their genesis to different magmatic events that could be temporally associated to some major lithostratigraphic units of Tapajós Domain: Cuiú-Cuiú Complex (2033-2005 Ma), Comandante Arara Formation (2020-2012 Ma) and Creporizão Intrusive Suite (1998-1957 Ma). However, the studied intrusive rocks did not show geochemical patterns directly correspondent to the highlighted units. Nevertheless, the temporal relation between these intrusive rocks and lithostratigraphic units of Tapajós Domain could be considerated an evidence of temporal, spatial and probably stratigraphic relationship between CSF and Tapajós Domain. Based on geochronological data, we also estimate at 2011 \pm 6 Ma the minimum sedimentation age of CSF, which also represents the age of the singenetic gold mineralization hosted in it.
\end{abstract}

Keywords: Amazonian Craton. Castelo dos Sonhos Formation. U-Pb geochronology. Geochemistry. Petrography. Intrusive rocks.

QUEIROZ, J. D. S., E. L. KLEIN \& J. B. RODRIGUES, 2016. Rochas intrusivas na Formação Castelo dos Sonhos, Cráton Amazônico: petrografia, geocronologia, geoquímica e implicações para as idades de sedimentação e da mineralização no depósito aurífero Castelo de Sonhos. Boletim do Museu Paraense Emílio Goeldi. Ciências Naturais 10(3): 341-380.

Autor para correspondência: Joana D’Arc da Silva Queiroz. Universidade Federal do Pará. Rua Augusto Corrêa, 1 - Guamá. Belém, PA, Brasil. CEP 66075-110 (joana.ddqueiroz@gmail.com).

Recebido em 25/02/2015

Aprovado em 30/03/2016

Responsabilidade editorial: Mário Augusto G. Jardim

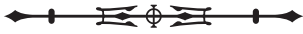




\section{INTRODUÇÃO}

A Formação Castelo dos Sonhos (Yokoi et al., 2001) é constituída por uma sequência metassedimentar que aflora na porção sudoeste do estado do Pará, na região limítrofe entre os domínios Tapajós e Iriri-Xingu, que integram, respectivamente, as províncias Tapajós-Parima e Amazônia Central, de acordo com a compartimentação do Cráton Amazônico proposta por Santos (2003) (Figura 1). Por estar situada em uma região limítrofe entre domínios tectônicos, esta unidade, que hospeda o depósito aurífero Castelo de Sonhos, tem sido incluída tanto no Domínio Iriri-Xingu quanto no Domínio Tapajós, o que a introduz e a torna relevante na discussão sobre a (re)definição de limites entre domínios/províncias tectônicas no Cráton Amazônico, uma discussão antiga que tem sido favorecida por dados obtidos em trabalhos recentes (Amaral, 1974; Tassinari \& Macambira, 1999 , 2004; Santos, 2003; Juliani et al., 2013; Guimarães et al., 2015; Vasquez et al., 2008a, 2013, 2014a, entre outros). Idades de 2083 Ma (U-Pb SHRIMP - Santos, 2003)e 2080 Ma (U-Pb LA-ICP-MS - Klein et al., 2014) em zircão detrítico marcam o intervalo máximo de sedimentação para a Formação Castelo dos Sonhos, que também revelou populações de cristais com idades variadas, do Riaciano ao Arqueano. A idade máxima de sedimentação em torno de 2,08 Ga e a suposta ausência de contribuição vulcânica levaram Vasquez et al. (2008b) a sugerirem que a deposição da formação se deu antes do abundante vulcanismo Orisiriano do Domínio Tapajós (2,0 a 1,98 Ga - Formação Vila Riozinho), isto é, a Formação Castelo dos Sonhos seria mais antiga do que as rochas conhecidas no Domínio Tapajós e as fontes dos sedimentos viriam de nordeste (Domínio Bacajá) e leste (Domínios Carajás e Rio Maria) da área de exposição da bacia (Santos, 2003). Em vista disto, Vasquez et al. (2008a, 2008b) posicionaram a formação no Domínio Iriri-Xingu.

Informações obtidas em furos de sondagem em vários setores da Formação Castelo dos Sonhos revelaram que esta unidade foi intrudida por rochas vulcânicas e plutônicas.
O estudo geocronológico dessas rochas possibilita sua comparação com unidades já conhecidas na região, permitindo ainda que seja estimada a idade mínima de deposição dos sedimentos da Formação Castelo dos Sonhos e da mineralização aurífera em paleoplacer nela hospedada.

Assim, este estudo apresenta características petrográficas, geoquímicas e idades de cristalização ( $U-P b$ em zircão, por LA-ICP-MS e SHRIMP) das rochas intrusivas na Formação Castelo de Sonhos. São sugeridas relações temporais entre as rochas estudadas e algumas unidades litoestratigráficas conhecidas no Domínio Tapajós. Além disso, apresenta-se para a Formação Castelo dos Sonhos uma idade mínima de sedimentação, que também representa a idade da mineralização aurífera nela hospedada. Com isso, espera-se contribuir para um melhor entendimento geológico do Cráton Amazônico na porção sudoeste do Pará, com possíveis implicações na discussão acerca da redefinição do limite tectônico entre os domínios Tapajós e Iriri-Xingu.

\section{CONTEXTO GEOLÓGICO REGIONAL}

Os domínios Tapajós e Iriri-Xingu (Figura 1) pertencem, respectivamente, às províncias Tapajós-Parima (2,031,86 Ga) e Amazônia Central (1,90-1,86 Ga), conforme a proposta de compartimentação do Cráton Amazônico de Santos (2003). O Domínio Tapajós ocupa a porção central da Província Tapajós-Parima e é limitado a leste pelo Domínio Iriri-Xingu, situado na porção meridional da Província Amazônia Central (Vasquez et al., 2008a).

O Domínio Tapajós é composto por raras rochas metavulcanossedimentares, gnaisses e várias gerações de granitoides e rochas vulcânicas relacionadas a possível ambiente de arco magmático, suítes plutônicas tardi a pós-orogênicas, rochas gabroicas intracontinentais, além de uma associação vulcano-plutônica intracontinental e coberturas sedimentares de rifte continental (Vasquez et al., 2008a). Os granitoides de arco magmático apresentam idades-modelo $T_{D M}$ paleoproterozoicas (2,09 a 2,16 Ga) e os valores positivos de $\varepsilon_{\mathrm{Nd}}(+2,6 \mathrm{a}+1,8)$ indicam 
contribuição de material juvenil em sua origem. As idades modelo $T_{\mathrm{DM}}$ e os valores fracamente negativos de $\varepsilon_{\mathrm{Nd}}$ das rochas vulcânicas mais antigas $\left(T_{\mathrm{DM}}=2,49\right.$ a $2,28 \mathrm{Ga} ; \varepsilon_{\mathrm{Nd}}$ $=-1,09$ a $-3,71)$ e dos granitoides tardiorogênicos $\left(T_{D M}\right.$ $=2,41$ a $2,26 \mathrm{Ga} ; \varepsilon_{\mathrm{Nd}}=-1,03$ a $\left.-2,68\right)$ demonstram pequena contribuição de crosta (continental?) mais antiga (Vasquez et al., 2008a). Para as rochas vulcânicas mais jovens, as idades-modelo e valores de $\varepsilon_{\mathrm{Nd}}\left(T_{\mathrm{DM}}\right.$ $=2,44$ a $2,30 \mathrm{Ga} ; \boldsymbol{\varepsilon}_{\mathrm{Nd}}=-2,26$ a $\left.-3,05\right)$ indicam fontes crustais paleoproterozoicas (Lamarão et al., 2005).

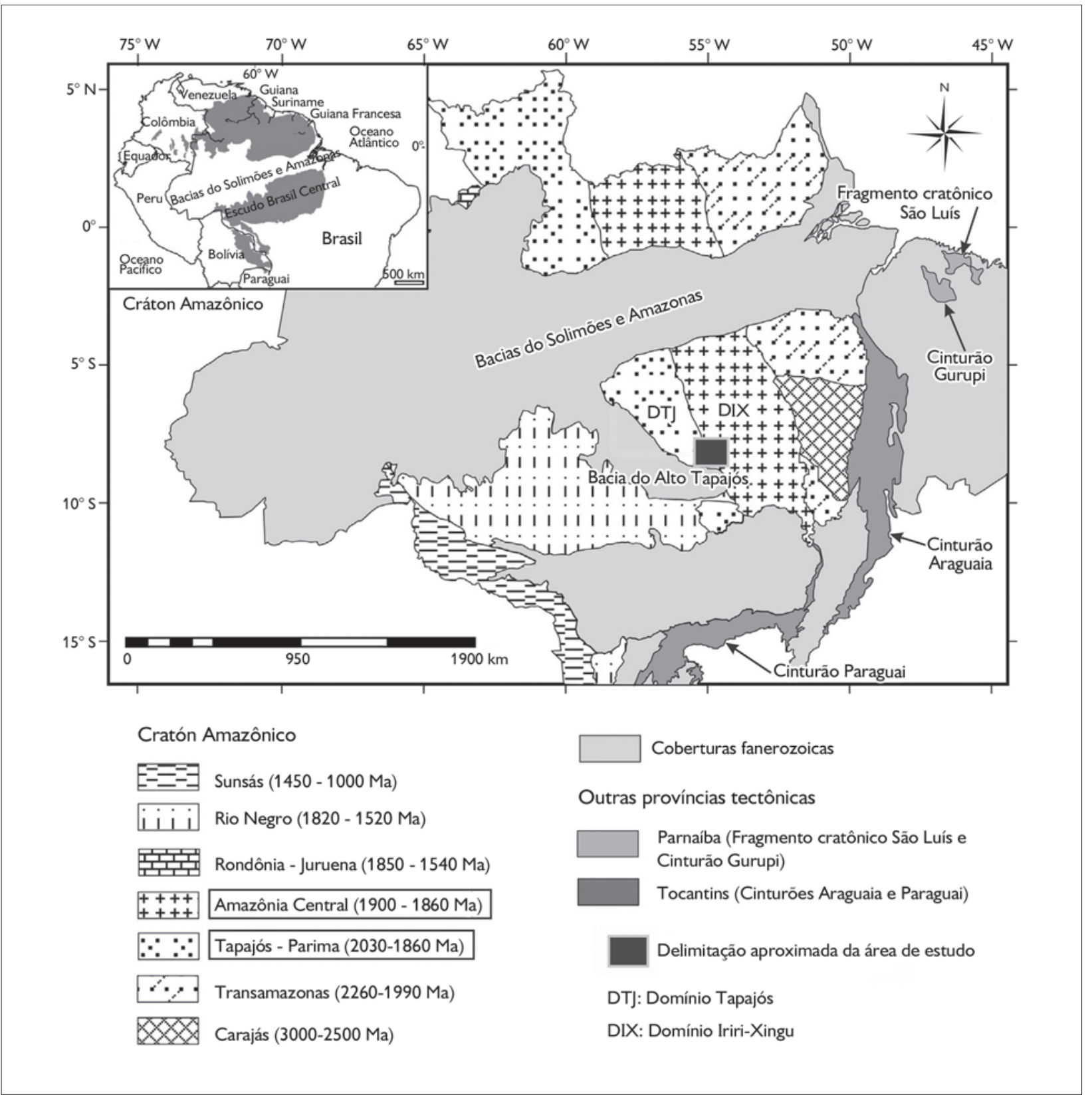

Figura 1. Localização dos domínios Tapajós e Iriri-Xingu em relação às províncias geocronológicas do Cráton Amazônico, de acordo com Santos (2003). Modificado de Vasquez et al. (2008a).

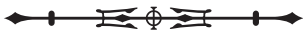


ODomínio Iriri-Xingu éformado predominantemente por uma associação vulcano-plutônica, além de sequências sedimentares de rifte continental. Idades-modelo $T_{D M}$ e valores de $\varepsilon_{\mathrm{Nd}}$ representativos das rochas vulcânicas ( $T_{\mathrm{DM}}$ $=2,60$ a $3,13 \mathrm{Ga} ; \varepsilon_{\mathrm{Nd}}=-6,3$ a $\left.-11,6\right)$ e dos granitoides relacionados $\left(T_{D M}=3,25\right.$ a $2,98 \mathrm{Ga} ; \varepsilon_{N d}=-7,9$ a - 12,2) revelaram significativa contribuição crustal arqueana (Teixeira et al., 2002; Vasquez, 2006).

Esses contrastes na assinatura isotópica das rochas relacionadas aos domínios Tapajós e Iriri-Xingu foram o principal critério usado para traçar o limite que os separa. Entretanto, o limite que vigora atualmente não está claramente definido, ainda se fazem necessários mais estudos geocronológicos e geoquímicos, mapeamento geológico e levantamentos aerogeofísicos de alta resolução na área.

Além disso, vem sendo demonstrada em trabalhos recentes (Vasquez et al., 2013, 2014a; Guimarães et al., 2015) a ocorrência de rochas com idades e características similares às encontradas no Domínio Tapajós cada vez mais a leste, ultrapassando o limite com o Domínio IririXingu, o que fundamentaria a expansão do Domínio Tapajós nessa direção. Contudo, mais estudos fazem-se necessários para delimitar melhor esses corpos e ratificar essa tendência de continuidade de unidades do Domínio Tapajós, a fim de tornar mais preciso não só o traçado do limite que atualmente o separa do Domínio Iriri-Xingu, mas o do próprio limite estabelecido entre as províncias Tapajós-Parima e Amazônia Central.

\section{DOMÍNIO TAPAJÓS}

Os limites do Domínio Tapajós (Figuras 1 e 2) são praticamente coincidentes com os da Província Aurífera do Tapajós (PAT), situada na porção central do Cráton Amazônico. A evolução geotectônica do Domínio Tapajós tem sido discutida de acordo com duas propostas principais. Por um lado, Santos et al. (2000, 2001, 2004) sugerem que houve acreção de cinco arcos magmáticos sucessivos, que teriam se formado durante dois eventos orogênicos (2040-1957 Ma e 1906-1886 Ma), aos quais se seguiu um período pós-orogênico, entre 1881 Ma e 1769 Ma. Já Vasquez et al. (2008a) propõem a formação de um único arco magmático (Arco Cuiú-Cuiú, < 2,0 Ga), que teria colidido contra um núcleo cratônico situado a leste (representado pela Província Amazônia Central), durante um único evento orogênico (Orogênese Cuiú-Cuiú), ao qual se seguiu a geração de sucessivos pulsos magmáticos em ambiente tardi a pós-orogênico e a implantação de riftes continentais, há aproximadamente 1,88 Ga.

De acordo com esta última proposta, a sequência metavulcanossedimentar do Grupo Jacareacanga ( $<2,01$ $\mathrm{Ga}$ - Santos et al., 2004) e o conjunto granito-gnáissico do Complexo Cuiú-Cuiú (2033-2005 Ma - Santos et al., 2000, 2001) representam o Arco Magmático Cuiú-Cuiú.

O Grupo Jacareacanga é constituído por metargilitos, metagrauvacas, xistos, metabasaltos, quartzitos, formações ferríferas bandadas e metassilexitos. Essas rochas, metamorfizadas, principalmente em condições de fácies xisto-verde, foram interpretadas como uma sequência turbidítica, intercalada com basaltos oceânicos e relacionada a bacias de retroarco e de fossa oceânica (Santos et al., 2000). De acordo com essa interpretação, os metabasaltos representariam o magmatismo primordial de fundo oceânico, associado à fase rifte, seguido pela sedimentação em fossa oceânica e bacias de retroarco, entre 2,1 e 2,01 Ga (Santos et al., 2000, 2004).

O Complexo Cuiú-Cuiú reúne granitoides e ortognaisses tonalíticos a granodioríticos, bandados e porfiroclásticos, com termos monzograníticos, quartzo dioríticos, quartzo monzodioríticos e dioríticos associados. Essas rochas contêm biotita e hornblenda, foram metamorfizadas em condições de fácies anfibolito superior e hospedam, localmente, lentes de leucogranitos com muscovita e, por vezes, com granada, contendo também enclaves microgranulares de rochas máficas, metaultramáficas e raros enclaves de gnaisses pelíticos (Vasquez et al., 2002, 2008b). 

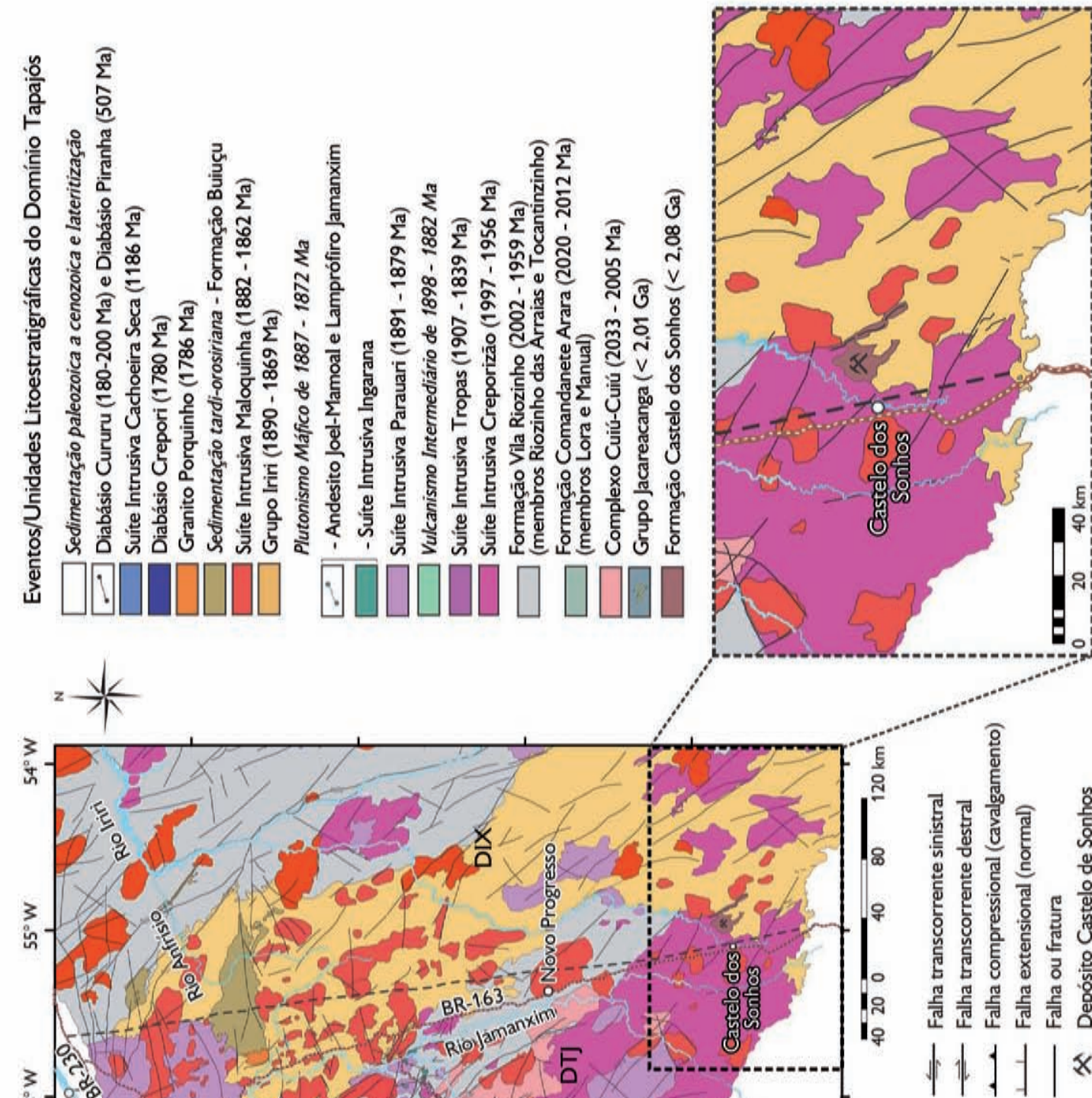

i⿱

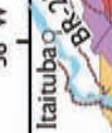

है-
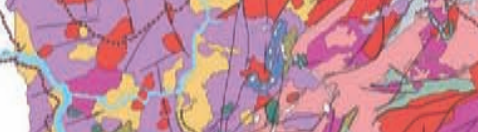

$-1$
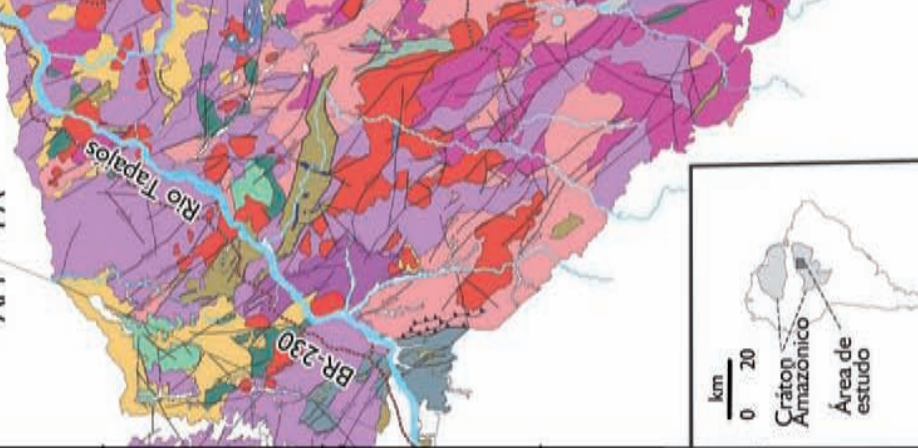
Os granitoides do complexo Cuiú-Cuiú distinguem-se dos demais no Domínio Tapajós por sua assinatura calcioalcalina mais primitiva, típica de arcos magmáticos relacionados à subducção de placa oceânica (Vasquez et al., 2002; Santos et al., 2004). A estreita associação espacial com as rochas supracrustais do Grupo Jacareacanga, a ocorrência de estruturas de cavalgamento oblíquo, feições de migmatização e intrusões leucograníticas peraluminosas no Complexo Cuiú-Cuiú são apontadas como evidências da colisão entre o Arco Magmático CuiúCuiú e um núcleo cratônico a leste (Vasquez et al., 2002). Corpos vulcânicos com idades similares foram interpretados como os equivalentes extrusivos dos granitoides do Complexo Cuiú-Cuiú e reunidos na Formação Comandante Arara (2020-2012 Ma - Vasquez et al., 2013), composta por andesitos a riodacitos e depósitos piroclásticos e epiclásticos.

As rochas vulcânicas intermediárias a félsicas da Formação Vila Riozinho (2000-1998 Ma - Lamarão et al., 2002), definidas na porção leste do Domínio Tapajós, apresentam assinatura calcioalcalina de alto Ka shoshonítica, típica de arcos magmáticos maturos. Considerando a afinidade geoquímica com ambiente de arco magmático e a ausência de sinais de metamorfismo ou deformação dúctil, Vasquez et al. (2008b) relacionaram essas rochas a uma etapa tardia da formação do Arco Cuiú-Cuiú. A oeste de sua área-tipo, Vasquez et al. (2013) identificaram rochas vulcânicas com idades de 2002 Ma correlatas à Formação Vila Riozinho.

Os granitoides da Suíte Intrusiva Creporizão (1997-1957 Ma - Vasquez et al., 2000a; Santos et al., 2001), representados por monzogranitos, sienogranitos, granodioritos, tonalitos e subordinados quartzomonzodioritos, apresentam biotita como principal mineral máfico, podendo também conter hornblenda e titanita. Essas rochas foram afetadas por deformação dúctil heterogênea e mostram texturas ígneas ainda preservadas ou exibem foliação protomilonítica, chegando a desenvolver faixas centimétricas a métricas de milonitos (Vasquez et al., 2000b, 2000c, 2002, 2008b). Os granitoides Creporizão apresentam assinatura calcioalcalina mais evoluída que a dos granitoides do Complexo CuiúCuiú e, para Vasquez et al. (2002, 2008b), sua origem está relacionada à fase tardia do evento colisional da Formação do Arco Cuiú-Cuiú. Entretanto, Santos et al. (2004) questionam a ausência de associações de rochas típicas de ambientes colisionais, como leucogranitos peraluminosos e paragnaisses, e relacionam a gênese desses granitoides à formação de um arco magmático mais jovem do que o Arco Cuiú-Cuiú, o Arco Creporizão.

Outros granitoides com assinatura calcioalcalina a calcioalcalina de alto K, pós-orogênicos em relação à Orogênese Cuiú-Cuiú (Vasquez et al., 2008a), foram reunidos nas suítes intrusivas Tropas (1907-1892 Ma - Santos et al., 2001, 2004), constituída por tonalitos, quartzo-dioritos, granodioritos e monzogranitos (Ferreira et al., 2004), e Parauari (1891-1879 Ma - Lamarão et al., 2002; Santos et al., 2000), na qual predominam granodioritos e monzogranitos (Vasquez et al., 2002).

O período de 1890 a $1870 \mathrm{Ma}$ foi marcado por magmatismo félsico intracontinental relacionado à extensão crustal orosiriana pós-orogênica a anorogênica, que resultou na formação das rochas vulcânicas do Grupo Iriri (1890-1870 Ma - Dall'Agnol et al.,1999; Moura et al., 1999; Vasquez et al., 1999; Santos et al., 2001; Lamarão et al., 2002).

Entre 1887 e 1881 Ma, o Domínio Tapajós é também marcado por significativo magmatismo máfico a intermediário intracontinental, que originou as rochas gabroicas calcioalcalinas de alto $\mathrm{K}$ da Suíte Intrusiva Ingarana (1887-1881 Ma - Vasquez et al., 2000a; Santos et al., 2004), além das rochas vulcânicas e subvulcânicas calcioalcalinas de alto Ka shoshoníticas (Ferreira, 2000; Vasquez \& Ricci, 2002) da Formação Bom Jardim (1881 Ma - Lamarão et al., 2002).

As manifestações magmáticas intracontinentais orosirianas são ainda representadas pelos granitoides tipo-A da Suíte Intrusiva Maloquinha (1882-1871 Ma - Vasquez et al., 1999; Santos et al., 2001), que, junto com as rochas do Grupo Iriri, formam uma associação vulcano-plutônica que foi relacionada ao desenvolvimento da Grande Província Ígnea Félsica (SLIP) Uatumã (Klein et al., 2012; Barreto et al., 2013).

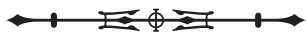


No final do Orosiriano, a implantação de riftes continentais resultou na deposição das coberturas sedimentares da Formação Buiuçu (Vasquez et al., 2008a) e da Formação Novo Progresso (<1857 Ma, Klein et al., 2014). O Estateriano é marcado por magmatismo félsico tipo A, representado pelo Granito Porquinho (1786 Ma - Santos et al., 2004) e por magmatismo tolé́tico, que originou os diques e soleiras do Diabásio Crepori (1780 Ma - Santos et al., 2002).

Após um hiato de quase $600 \mathrm{Ma}$, um evento magmático tolé́tico do Calimmiano marcou o reinício da atividade magmática no Domínio Tapajós, levando à formação das rochas da Suíte Intrusiva Cachoeira Seca (1186 Ma - Santos et al., 2002).

○ quadro estratigráfico do Domínio Tapajós é completado por unidades resultantes de magmatismo toleítico associado à formação de riftes, como o Diabásio Piranha (507 Ma) e o Diabásio Cururu (180-200 Ma), e por depósitos sedimentares paleozoicos a cenozoicos.

\section{DOMÍNIO IRIRI-XINGU}

O Domínio Iriri-Xingu ou Tafrógeno do Iriri tem sua evolução associada à extensão e ao adelgaçamento crustal que ocorreram após o amalgamento de massas continentais, durante o Riaciano e o Orosiriano, resultando na formação de supercontinentes no final do Paleoproterozoico (Brito Neves et al., 1995). Este domínio, com escassa cartografia geológica, é constituído por uma expressiva associação vulcano-plutônica orosiriana intracontinental, associada ao magmatismo Uatumã, e por coberturas sedimentares, cuja deposição está relacionada à evolução de um rifte continental formado entre o Orosiriano e o Estateriano (Vasquez et al., 2008a).

Essa associação vulcano-plutônica é representada principalmente pelas rochas vulcânicas félsicas do Grupo Iriri (1886 \pm 3 Ma - Teixeira et al., 2002) e por granitoides calcioalcalinos de alto $\mathrm{K}$ a alcalinos, que carecem de estudos petrográficos e geocronológicos e ainda não receberam denominação formal (Macambira \& Vale, 1997; Vasquez et al., 2008b).
É importante destacar que, em áreas tipicamente atribuídas ao Grupo Iriri (magmatismo Uatumã), nos domínios Tapajós e Iriri-Xingu, têm sido encontradas rochas vulcânicas e piroclásticas com características geoquímicas e idades diferentes daquele grupo (Fernandes et al., 2011; Guimarães et al., 2015; Semblano et al., 2014; Tokashiki et al., 2014).

\section{FORMAÇÃO CASTELO DOS SONHOS}

Devido à localização tectônica ainda, de certo modo, imprecisa da Formação Castelo dos Sonhos, situada em região limítrofe entre os domínios Tapajós e Iriri-Xingu, e considerando a indefinição e a discussão que ainda persistem em relação ao limite que atualmente separa esses domínios, optou-se por descrever em separado a Formação Castelo dos Sonhos. Neste tópico, é adotada a proposta litoestratigráfica mais recente de Vasquez et. al., (2014b; Figura 2), na qual a Formação Castelo dos Sonhos é considerada parte do Domínio Tapajós, e não mais do Domínio Iriri-Xingu (Vasquez et al., 2008a, 2008b).

A Formação Castelo dos Sonhos (Yokoi et al., 2001) é uma sequência metassedimentar constituída principalmente por metaquartzoarenitos e metaconglomerados, localmente milonitizados, interpretados, respectivamente, como depósitos distais e proximais de um complexo aluvial dominado por rios entrelaçados em associação com leques aluviais (Alkmim, 2011). Esta sequência metassedimentar foi intrudida por rochas hipoabissais félsicas e máficas (Yokoi et al., 2001), além de granitoides e rochas vulcânicas (constatado em furos de sondagem).

De modo geral, os metarenitos são médios a grossos, mal selecionados e compostos por quartzo, muscovita, clorita, magnetita, hematita, monazita e zircão. Os metaconglomerados, sustentados por matriz ou clastos, são polimíticos e compostos por clastos de dimensões centimétricas a métricas, representados dominantemente por quartzo, além de quartzito, formações ferríferas bandadas, xistos etc. A matriz é composta por quartzo de granulação média a grossa, muscovita, clorita, magnetita, hematita, turmalina, monazita e zircão. Tanto nos 
metarenitos quanto nos metaconglomerados, sulfetos (pirita e calcopirita) são raros e ocorrem como finos cristais intergranulares, geralmente idiomórficos. Localmente, metarenitos e metaconglomerados apresentam lamelas de muscovita recristalizadas, contorcidas e/ou exibindo extinção ondulante (Queiroz, 2015).

A datação de metarenitos desta unidade revelou populações de zircão detrítico com idades entre 3105 e 2083 Ma (U-Pb SHRIMP - Santos, 2003) e 3318 e 2080 Ma (U-Pb LA-ICP-MS - Klein et al., 2014), estabelecendo o intervalo máximo da sedimentação em 2,08 Ga.

O significado tectônico da Formação Castelo dos Sonhos não é bem compreendido, e esta unidade tem sido interpretada como remanescente de uma bacia de antepaís relacionada a um orógeno transamazônico (Vasquez et al., 2008a).

Em relação ao depósito Castelo de Sonhos, o minério aurífero está associado principalmente aos pacotes de metaconglomerados (mineralização singenética), todavia, sua ocorrência também em planos de fratura de metarenitos indica que houve remobilização do ouro (mineralização epigenética), e o depósito foi interpretado como do tipo paleoplacer modificado (Queiroz, 2015).

\section{PROCEDIMENTOS ANALÍTICOS}

Análises químicas em rocha total foram realizadas no laboratório SGS GEOSOL, em Vespasiano, Minas Gerais. Após fusão com metaborato/tetraborato de lítio e digestão em ácido nítrico diluído, os elementos maiores foram analisados por ICP-ES (Inductively Coupled Plasma Emission Spectrometry) e os elementos-traço, incluindo os elementos terras-raras, por ICP-MS (Inductively Coupled Plasma Mass Spectrometry). O protocolo analítico incluiu a análise de matérias de referência: STD SO-18, OREAS45PA, OREAS76A e DS7. Diagramas geoquímicos foram gerados com o auxílio do programa GCDkit (Janousek et al., 2006).

A determinação das idades U-Pb (SHRIMP - Sensitive High-Resolution Ion Microprobe) foi realizada no Centro de Pesquisas Geocronológicas da Universidade de São Paulo
(CPGeo-USP). Técnicas gravimétricas foram empregadas para a redução de amostras e a separação dos cristais de zircão foi efetuada em lupa binocular. Posteriormente, os cristais foram montados em resina epoxy, junto com o padrão TEMORA-2 (Blacket al., 2004), e polidos para expor o interior dos grãos. As seções polidas foram cobertas com Au e examinadas em microscópio eletrônico FEI Quanta 250, equipado com detectores de elétrons secundários e catodoluminescência, no CPGeo-USP.

As condições de operação mais comuns foram: corrente de emissão $=60 \mu \mathrm{A}$, voltagem de aceleração $=$ $15.0 \mathrm{kV}$, diâmetro do filamento $=7 \mu \mathrm{m}$, tempo de aquisição $=200 \mu$ s e resolução de $1024 \times 884$. Posteriormente, as seções polidas foram analisadas pela técnica isotópica U-Pb, utilizando uma máquina SHRIMP-II, de acordo com os procedimentos analíticos apresentados por Williams (1998). Correção para o Pb comum foi feita com base no ${ }^{204} \mathrm{~Pb}$ medido, e o erro típico para a razão ${ }^{206} \mathrm{~Pb} /{ }^{38} \mathrm{U}$ é menor que $2 \%$. Abundância de urânio e razões U/Pb foram calibradas em relação ao padrão TEMORA. Utilizou-se o programa Isoplot ${ }^{\circledR}$, versão 3.0 (Ludwig, 2003), para calcular as idades. Erros são reportados como desvios de $1 \sigma$ e as idades calculadas apresentam nível de 95\% de confiança.

As mesmas técnicas de redução de amostras, separação e imageamento dos cristais de zircão, descritas no método anterior, foram empregadas para a seleção dos cristais analisados pelo método U-Pb (LA-ICP-MS Laser Ablation Induced Coupled Mass Spectrometry). As análises foram realizadas no Laboratório de Geocronologia da Universidade de Brasília, utilizando-se New Wave UP213 Laser Ablation System acoplado a um ICP-MS Neptune. Dados isotópicos foram adquiridos no modo estático com spots de 25 e 40 um. O zircão GJ-1 (Jackson et al., 2004) foi utilizado como padrão para corrigir fracionamentos de elementos por indução do Laser e discriminação de massa instrumental. A cada quatro ou dez spots analisados nas amostras, duas análises do padrão GJ-1 foram realizadas. Erros externos foram calculados com a propagação do erro das medidas individuais do 
padrão GJ-1 e das medidas individuais de cada amostra de zircão (ou ponto analítico).

\section{RESULTADOS}

\section{PETROGRAFIA}

As estimativas das composições modais das rochas estudadas são apresentadas na Tabela 1. Com base nas diferenças mineralógicas e texturais observadas, cinco tipos petrográficos foram distinguidos: dacito porfirítico $(\mathrm{DP})$, biotita granodiorito $(\mathrm{BG})$, biotita monzogranito (BM), muscovita monzogranito (MM) e sienogranito (SG).

Ressalta-se que se trata de rochas não aflorantes na área de estudo e que, portanto, as relações de intrusão observadas entre alguns desses litotipos e as rochas da Formação Castelo dos Sonhos foram constatadas em testemunhos de sondagem.

Tabela 1. Síntese das características distintivas das rochas estudadas. Legendas: $\mathrm{DP}=$ dacito porfirítico; $\mathrm{BG}=$ biotita granodiorito; $\mathrm{BM}=$ biotita monzogranito; $\mathrm{MM}=$ muscovita monzogranito; SG = sienogranito; Qtz = quartzo; Pl = plagioclásio; Kfs = feldspato potássico; Amp = anfibólio; Bt = biotita; Mag = magnetita; Zrn = zircão; Ap = apatita; Ser = sericita; Argilom. = argilominerais; Ms =muscovita; $\mathrm{Cal}=$ calcita; $\mathrm{Chl}=$ clorita; $\mathrm{Ep}=$ epidoto; Ttn = titanita; Py = pirita; Cpy = calcopirita.

\begin{tabular}{|c|c|c|c|c|c|}
\hline Litotipo & $\mathrm{DP}$ & BG & BM & MM & SG \\
\hline $\begin{array}{c}\text { Minerais } \\
\text { essenciais (\%) }\end{array}$ & $\begin{array}{l}\text { Qtz: } 20-25 \\
\text { Pl: } 50-55 \\
\text { Kfs: } 1-3\end{array}$ & $\begin{array}{l}\text { Qtz: } 15-20 \\
\text { Pl: } 40-45 \\
\text { Kfs: } 10-15\end{array}$ & $\begin{array}{l}\text { Qtz: } 20-25 \\
\text { Pl: } 30-35 \\
\text { Kfs: } 25-30\end{array}$ & $\begin{array}{l}\text { Qtz: } 20-25 \\
\text { Pl: } 35-40 \\
\text { Kfs: } 25-30\end{array}$ & $\begin{array}{l}\text { Qtz: } 20-25 \\
\text { Pl: } 10-15 \\
\text { Kfs: } 50-55\end{array}$ \\
\hline $\begin{array}{c}\text { Minerais } \\
\text { varietais (\%) }\end{array}$ & $\begin{array}{l}\text { Amp: } 3-5 \\
\text { Bt: } 5-10\end{array}$ & Bt: $5-10$ & Bt: 3-6 & Ms: $1-3$ & - \\
\hline $\begin{array}{c}\text { Minerais } \\
\text { acessórios (\%) }\end{array}$ & $\begin{aligned} \text { Mag }+ & \text { Zrn }+ \text { Ap: } \\
& \leq 1\end{aligned}$ & $\begin{array}{c}\text { Mag }+ \text { Zrn }+ \\
\text { Ap: } \leq 1\end{array}$ & $\begin{array}{c}\text { Mag }+ \text { Zrn }+ \\
\text { Ap: } \leq 1\end{array}$ & Mag + Zrn: $\leq 1$ & Mag $+Z r n+$ Ap: $\leq 11$ \\
\hline $\begin{array}{c}\text { Minerais } \\
\text { pós-magmáticos/ } \\
\text { hidrotermais }\end{array}$ & $\begin{array}{l}\text { Ser, Argilom.,Ms, } \\
\text { Cal, Chl, Qtz, } \\
\text { Ep,Ttn, Py, Cpy }\end{array}$ & $\begin{array}{l}\text { Ser, Argilom., } \\
\text { Ms, Chl, Qtz, } \\
\text { Cal, Ep }\end{array}$ & $\begin{array}{l}\text { Ser, Ms, } \\
\text { Argilom., } \\
\text { Chl, Ep }\end{array}$ & $\begin{array}{l}\text { Ser, Ms, Argilom.,Chl, Cal, } \\
\text { Qtz, Py, Cpy, Ep }\end{array}$ & $\begin{array}{l}\text { Ser, Ms, Argilom., } \\
\text { Chl, Cal, Ep }\end{array}$ \\
\hline Textura/estrutura & $\begin{array}{l}\text { Porfirítica, } \\
\text { maciça, foliada }\end{array}$ & $\begin{array}{l}\text { Hipidiomórfica } \\
\text { inequigranular } \\
\text { maciça, foliada }\end{array}$ & $\begin{array}{l}\text { Hipidiomórfica } \\
\text { inequigranular } \\
\text { maciça }\end{array}$ & $\begin{array}{c}\text { Alotriomórficai nequigranular } \\
\text { maciça, foliada }\end{array}$ & $\begin{array}{c}\text { Hipidiomórficai nequigranular } \\
\text { maciça }\end{array}$ \\
\hline Granulação & $\begin{array}{l}\text { Fina a média } \\
\text { (matriz) }\end{array}$ & Média & Média & Média & Média a grossa \\
\hline $\begin{array}{c}\text { Índice de saturação } \\
\text { em alumina }\end{array}$ & $\begin{array}{l}\text { Metaluminoso } \\
\text { a fracamente } \\
\text { peraluminoso }\end{array}$ & $\begin{array}{l}\text { Fracamente } \\
\text { peraluminoso }\end{array}$ & $\begin{array}{l}\text { Fracamente } \\
\text { peraluminoso }\end{array}$ & $\begin{array}{l}\text { Fracamente } \\
\text { peraluminoso }\end{array}$ & $\begin{array}{l}\text { Fracamente } \\
\text { peraluminoso }\end{array}$ \\
\hline $\begin{array}{l}\text { Assinatura } \\
\text { geoquímica }\end{array}$ & Calcico-alcalina & Calcico-alcalina & Calcico-alcalina & Alcalina & Alcalina \\
\hline $\begin{array}{l}\text { Ambiente } \\
\text { tectônico }\end{array}$ & $\begin{array}{l}\text { Arco vulcânico/ } \\
\text { pós-colisional }\end{array}$ & $\begin{array}{l}\text { Arco vulcânico/ } \\
\text { pós-colisional }\end{array}$ & $\begin{array}{l}\text { Arco vulcânico/ } \\
\text { pós-colisonal }\end{array}$ & $\begin{array}{l}\text { Arco vulcânico/ } \\
\text { pós-colisonal }\end{array}$ & $\begin{array}{l}\text { Arco vulcânico/ } \\
\text { pós-colisional }\end{array}$ \\
\hline Idade (Ma) & $2011 \pm 6$ & $1976 \pm 7$ & $1918 \pm 9$ & $1978 \pm 6$ & - \\
\hline Método & LA-ICP-MS & SHRIMP & SHRIMP & SHRIMP & SHRIMP \\
\hline $\begin{array}{c}\text { Correlação } \\
\text { temporal com } \\
\text { unidades do } \\
\text { Domínio Tapajós }\end{array}$ & $\begin{array}{l}\text { Complexo } \\
\text { Cuiú-Cuiú; } \\
\text { Formação } \\
\text { Comandante Arara }\end{array}$ & $\begin{array}{l}\text { Suíte Intrusiva } \\
\text { Creporizão }\end{array}$ & $\begin{array}{l}\text { Suíte Intrusiva } \\
\text { Tropas? }\end{array}$ & Suíte Intrusiva Creporizão & - \\
\hline
\end{tabular}

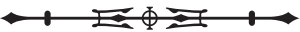




\section{Dacito porfirítico}

Corta metaquartzoarenitos da Formação Castelo dos Sonhos. Apresenta matriz de coloração cinza-escura, na qual se destacam fenocristais milimétricos de plagioclásio. As porções mais alteradas e/ou deformadas caracterizam-se por tons esverdeados e avermelhados, pela ocorrência de vênulas e pelo desenvolvimento de foliação milonítica (Figuras 3Aa 3E).

Ao microscópio (Figuras 4A a 4F), fenocristais de plagioclásio destacam-se em uma matriz de granulação fina a média, composta por quartzo, plagioclásio, biotita, anfibólio, feldspato potássico, além de magnetita, zircão e apatita. Os fenocristais de plagioclásio (Figura 4A) são subédricos e contêm inclusões de zircão e apatita, encontram-se moderada a fortemente sericitizados e localmente saussuritizados, alguns cristais exibem fraturas e/ou maclas deformadas. Em relação aos componentes da matriz, o quartzo é anédrico, exibe extinção ondulante moderada a forte e contatos intercristalinos irregulares. Em algumas porções, cristais de granulação fina exibem contatos poligonais (Figura 4E). Quartzo também ocorre como cristais vermiculares em intercrescimentos granofíricos. O plagioclásio, subédrico a anédrico, encontra-se leve a intensamente sericitizado e/ou argilizado, e alguns cristais exibem maclas deformadas.

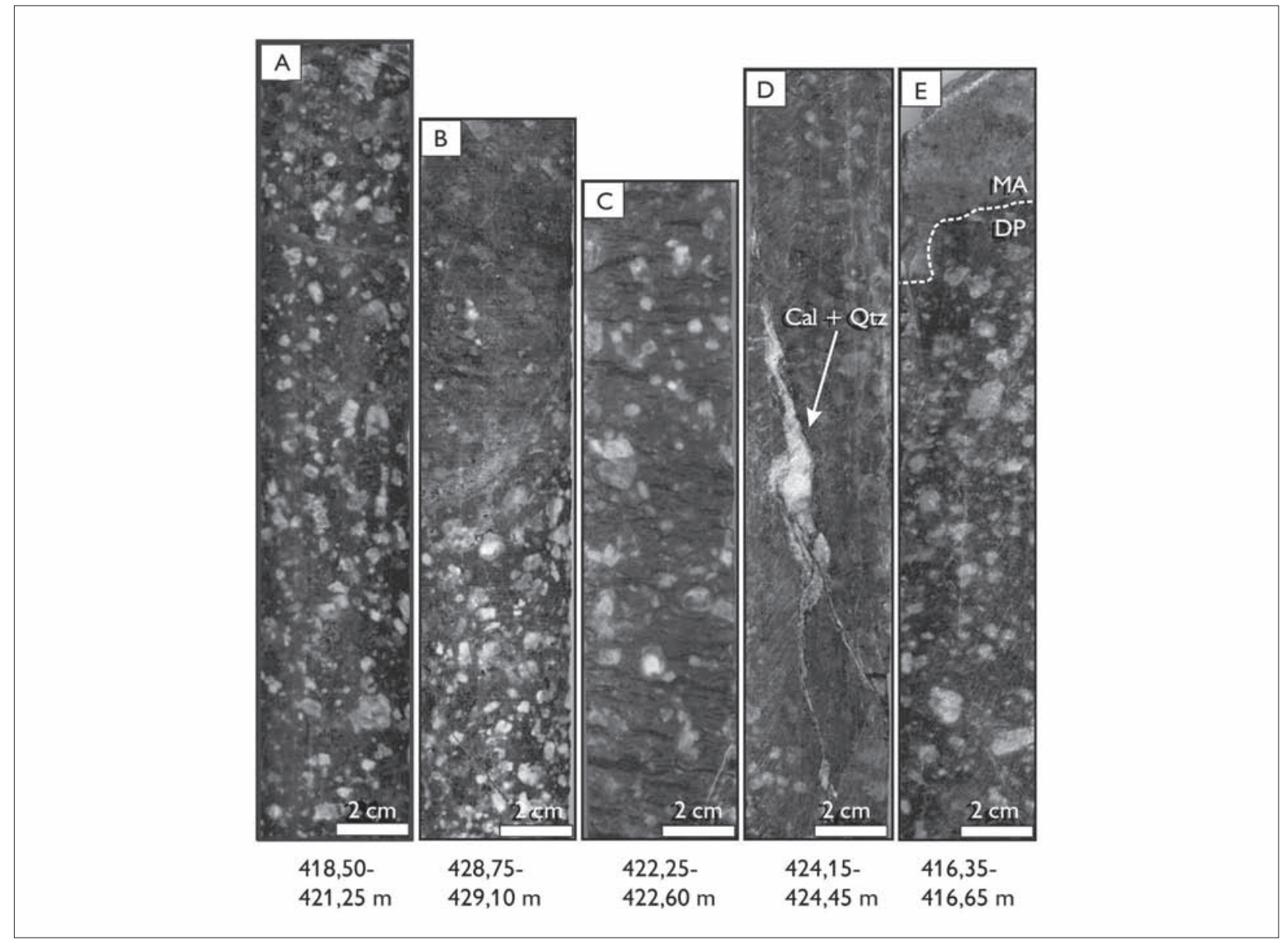

Figura 3. Aspectos macroscópicos do DP: A) rocha mais preservada de alteração hidrotermal e deformação; B e C) rocha fortemente deformada/hidrotermalizada, exibindo foliação milonítica localmente ondulada; D) rocha fortemente hidrotermalizada e cortada por vênula de calcita e quartzo; E) contato entre DP e metarenito da Formação Castelo dos Sonhos. Legendas: DP = dacito porfirítico; $\mathrm{MA}=$ metarenito; Cal = calcita; Qtz = quartzo.

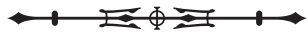




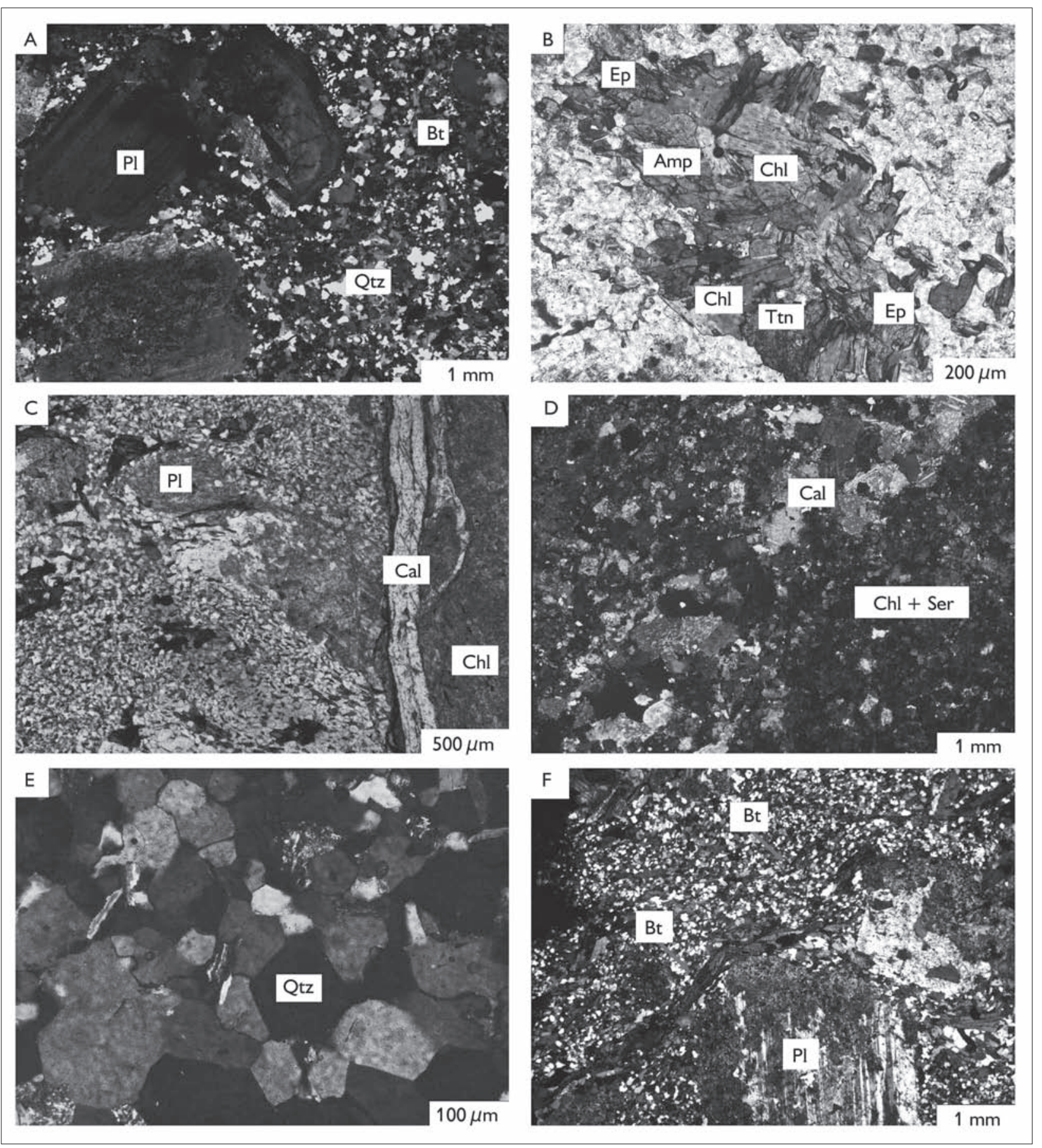

Figura 4. Aspectos microscópicos do DP: A) textura porfirítica (notar fenocristal de plagioclásio fraturado na porção superior esquerda da imagem); B) clorita, titanita e epidoto resultantes da alteração do anfibólio; C) porfiroclasto amendoado de plagioclásio, contornado por lamelas de biotita (porção superior esquerda da imagem) e vênula de calcita (à direita); D) alteração hidrotermal pervasiva, representada por agregados de clorita, calcita e sericita; E) cristais de quartzo recristalizados, exibindo contatos poligonais; F) lamelas de biotita orientadas, definindo foliação milonítica ondulada. Legendas: DP = dacito porfirítico; Qtz = quartzo; Pl = plagioclásio; Bt = biotita; Cal = calcita; Chl $=$ clorita; Ser = sericita; Ttn = titanita; Ep = epidoto; Amp = anfibólio. 
As lamelas de biotita são subédricas, contêm inclusões de apatita e encontram-se pouco a intensamente alteradas para clorita, titanita, epidoto e, eventualmente, para muscovita. $\bigcirc$ anfibólio, subédrico a anédrico, contém inclusões de magnetita e zircão, encontra-se incipiente a intensamente alterado para biotita, clorita, titanita e epidoto (Figura 4B), e desenvolve fenocristais ocasionalmente. $O$ feldspato potássico é raro, anédrico a subédrico, levemente pertítico e encontra-se pouco a moderadamente alterado para sericita e argilominerais.

De modo geral, a rocha foi fraca a fortemente afetada por alteração hidrotermal, que se manifesta de forma venular (Figuras 3D e 4C), por substituição seletiva de minerais primários (Figuras 4A e 4B) e de forma pervasiva (Figuras 3B e 4D).

A rocha foi também fraca a fortemente afetada por deformação dúctil a rúptil. A deformação dúctil é caracterizada pelo desenvolvimento de foliação milonítica, por vezes ondulada (Figuras 3C e 4F), definida pela orientação preferencial de lamelas de biotita, que contornam, localmente, porfiroclastos amendoados de plagioclásio (Figura 4C). Além disso, o quartzo apresenta extinção ondulante forte e constitui agregados poligonais recristalizados (Figura 4E), e o plagioclásio (fenocristais e matriz) exibe maclas deformadas. Microfraturas em fenocristais de plagioclásio (Figura 4A) e na magnetita, assim como vênulas multidirecionais caracterizam a deformação rúptil (Figuras 3D e 4C).

\section{Biotita granodiorito}

É intrusivo em metaconglomerados da Formação Castelo dos Sonhos. Apresenta coloração cinza-clara nas porções mais frescas e, quando alterado e/ou deformado, distingue-se por tons predominantemente avermelhados, pela ocorrência de vênulas e pelo desenvolvimento de foliação milonítica (Figuras 5A a 5D).

Ao microscópio (Figuras 5E a 5H), exibe textura hipidiomórfica inequigranular e granulação média (Figura 5E). $\bigcirc$ quartzo, anédrico, apresenta contatos irregulares a retilíneos com plagioclásio e microclina. Em geral, os cristais exibem extinção ondulante moderada a forte, havendo formação subordinada de subgrãos e ocorrência local de cristais com contatos poligonais entre si. Quartzo também ocorre em intercrescimentos mirmequíticos. O plagioclásio, subédrico a anédrico, encontra-se leve a intensamente sericitizado e/ou argilizado (Figura 5E), e localmente saussuritizado. Alguns cristais apresentam zoneamento normal, evidenciado por núcleos mais intensamente alterados. A microclina ocorre como cristais subédricos a anédricos, pouco a moderadamente pertíticos, leve a intensamente argilizados e parcialmente sericitizados. As lamelas de biotita são subédricas e encontram-se fracamente a intensamente alteradas para clorita, muscovita, titanita e epidoto (Figura 5F).

A rocha foi fraca a moderadamente afetada por alteração hidrotermal, que ocorre principalmente pela substituição seletiva de minerais primários (Figura 5E e 5F). Os estilos venular (Figuras 5C e 5G) e pervasivo (Figura $5 \mathrm{H}$ ) ocorrem de forma subordinada.

Além disso, a rocha foi leve a intensamente afetada por deformação dúctil a rúptil. Nas porções afetadas por deformação dúctil, o plagioclásio apresenta maclas deformadas e o quartzo exibe extinção ondulante forte, desenvolve subgrãos e, ocasionalmente, constitui tramas recristalizadas com contatos poligonais ou interlobados. Nas porções mais intensamente deformadas, porfiroclastos amendoados de plagioclásio acompanham a foliação milonítica, geralmente ondulada (Figura 5G), definida pela orientação preferencial de lamelas de biotita e pelo estiramento do quartzo, que forma lentes descontínuas. Feições de deformação rúptil ocorrem localmente e são representadas por vênulas (Figuras $5 \mathrm{C}$ e 5G) e microfraturas em cristais de microclina e plagioclásio.

\section{Biotita monzogranito}

Sua natureza intrusiva na sequência metassedimentar da Formação Castelo dos Sonhos não foi observada. Apresenta coloração cinza-clara nas porções mais frescas, 


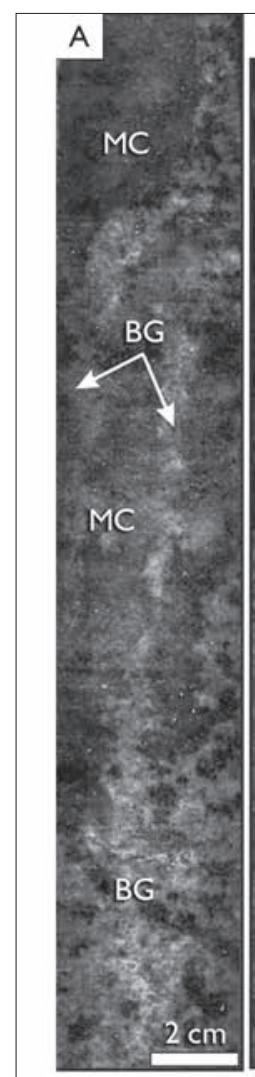

$56,05-$

$56,95 \mathrm{~m}$

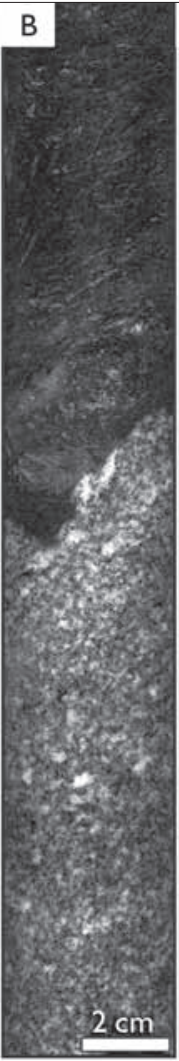

$60,75-$

$60,95 \mathrm{~m}$

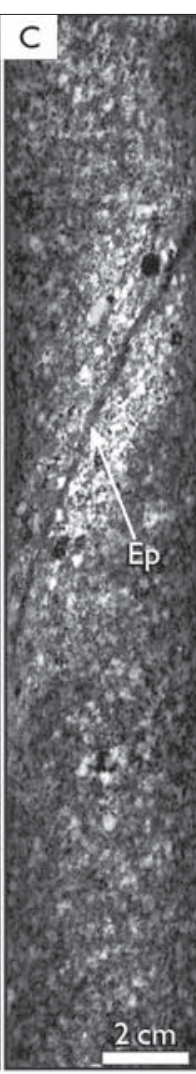

$62,90-$

$63,00 \mathrm{~m}$
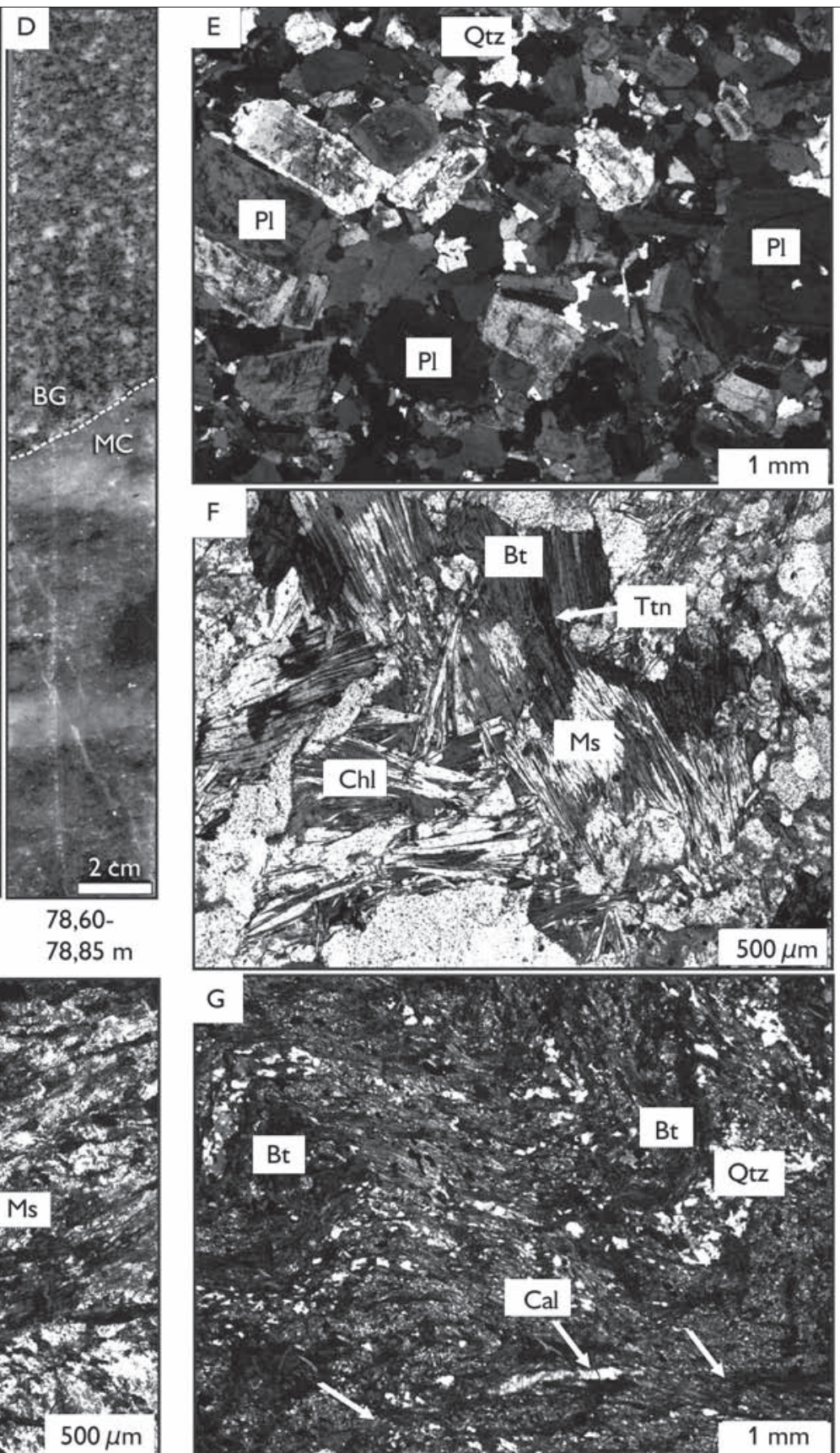

Figura 5. Aspectos macro e microscópicos do BG: A) apófises do BG intrudem metaconglomerado da Formação Castelo dos Sonhos; B) BG maciço e preservado de alteração hidrotermal e deformação (porção inferior), e intensamente hidrotermalizado e deformado, exibindo foliação milonítica (porção superior); C) BG hidrotermalizado cortado por vênula de epidoto, que desenvolve halo de alteração lateral; D) contato entre BG e metaconglomerado; E) textura granular hipidiomórfica; F) biotita quase completamente substituída por muscovita, clorita e titanita; G) foliação milonítica ondulada, definida pela orientação de quartzo e lamelas de biotita (na porção inferior da imagem, vênula de calcita - setas - corta a foliação); $H$ ) agregados de clorita e muscovita, caracterizando alteração hidrotermal pervasiva. Legendas: BG = biotita granodiorito; MC = metaconglomerado; Qtz = quartzo; Pl = plagioclásio; Bt = biotita; Cal = calcita; Chl = clorita; $\mathrm{Ms}$ = muscovita; Ttn = titanita; Ep = epidoto. 
adquirindo tons predominantemente esverdeados quando alterado (Figura 6A).

Ao microscópio (Figuras 6B a 6E), apresenta textura hipidiomórfica inequigranular e granulação média (Figura 6B). O quartzo é anédrico, exibe extinção ondulante moderada a fortee, porvezes, forma subgrãos (Figura 6D), estando também presente como cristais vermiculares em intercrescimentos mirmequíticos. $\bigcirc$ plagioclásio é subédrico a anédrico, contém inclusões de zircão e apatita, encontrando-se leve a moderadamente sericitizado e/ou argilizado (Figura 5B), com alteração local para muscovita, clorita e epidoto. De modo geral, a alteração é mais marcante em cristais zonados, que apresentam núcleos mais intensamente alterados.
Localmente, alguns cristais exibem maclas acunhadas (Figura 6E). A microclina ocorre como cristais subédricos a anédricos, por vezes poiquilíticos, que se encontram fraca a intensamente argilizados e parcialmente sericitizados. Alguns cristais apresentam discretos intercrescimentos micropertíticos do tipo mancha. Ortoclásio é raro, subédrico, apresenta maclamento Carlsbad e, localmente, forma cristais poiquilíticos. As lamelas de biotita são subédricas a anédricas, contêm inclusões de apatita e encontram-se pouco a intensamente alteradas, principalmente para muscovita (Figura 6C), além de clorita, epidoto e finos minerais opacos. A rocha foi incipiente a moderadamente afetada por alteração hidrotermal, apresentando as texturas ígneas

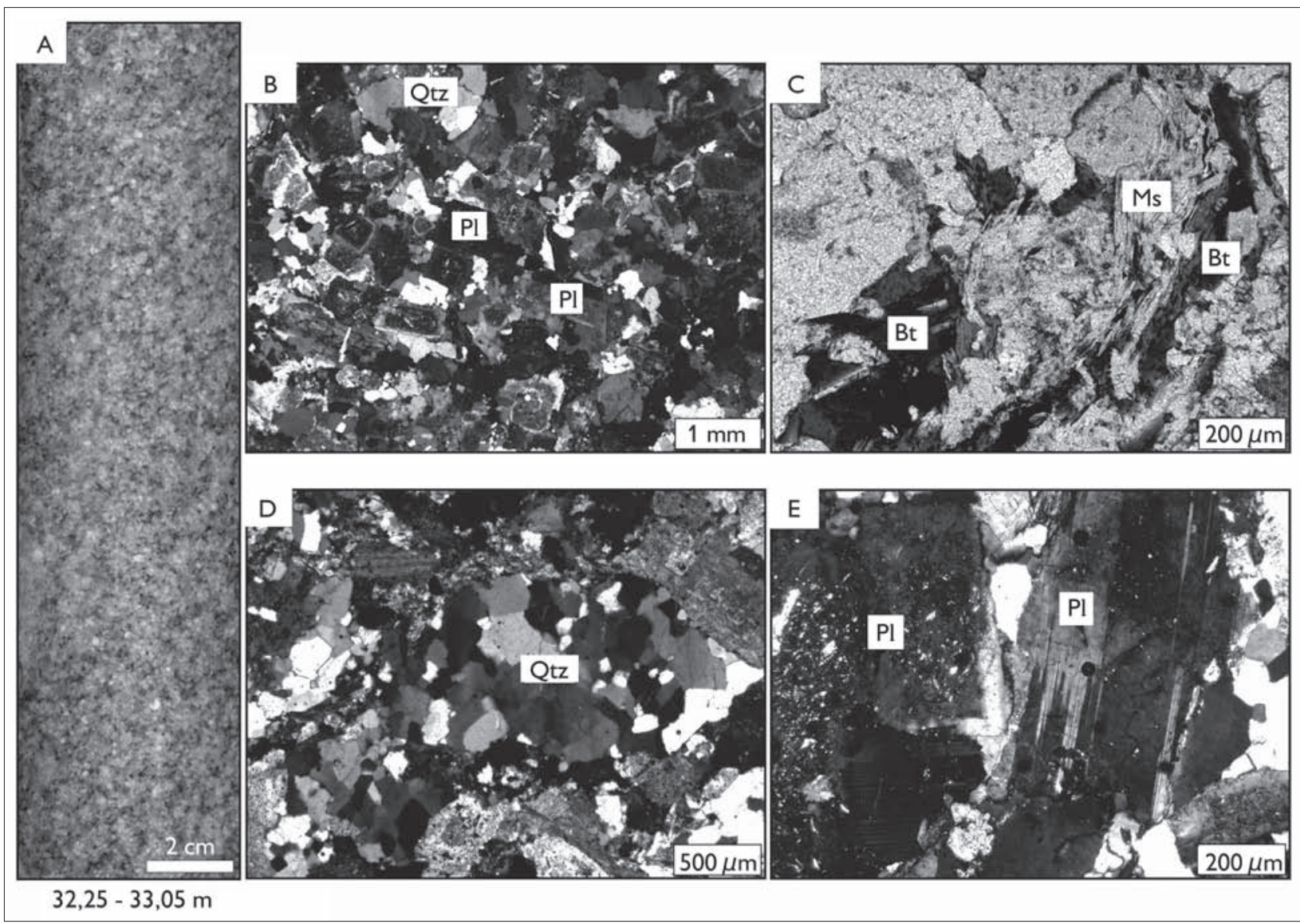

Figura 6. Aspectos macro e microscópicos do BM: A) BM maciço e levemente alterado; B) textura granular hipidiomórfica; C) muscovita secundária resultante da alteração da biotita; D) cristais de quartzo com extinção ondulante forte, formando subgrãos; E) cristais de plagioclásio levemente sericitizados (o cristal à direita exibe maclas acunhadas). Legendas: BM = biotita monzogranito; Qtz = quartzo; Pl $=$ plagioclásio; $\mathrm{Bt}=$ biotita; Ms = muscovita.

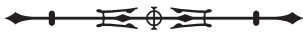


originais bem preservadas (Figuras 6A e 6B). A alteração hidrotermal se manifesta pela substituição seletiva de minerais primários (Figuras 6B, 6C e 6E).

Feições deformacionais ocorrem de forma pontual. Extinção ondulante forte em cristais de quartzo, acompanhada da formação de subgrãos (Figura 6D) e do acunhamento das maclas dos cristais de plagioclásio (Figura 6E) são representativas de deformação em regime rúptil-dúctil; já o fraturamento de cristais de plagioclásio e magnetita caracteriza deformação rúptil.

\section{Muscovita monzogranito}

Sua natureza intrusiva em relação às rochas da Formação Castelo dos Sonhos não foi observada. Apresenta coloração rosada a levemente avermelhada nas porções mais frescas, adquire coloração fortemente avermelhada e/ou tons de verde a cinza-escuro nas mais alteradas, e desenvolve foliação milonítica nas porções mais fortemente deformadas (Figuras 7A, 7B e 7F).

Ao microscópio (Figuras 7C a 7F), apresenta textura alotriomórfica inequigranular e granulação média (Figura 7C). O quartzo, anédrico, exibe extinção ondulante moderada a forte, constitui localmente subgrãos e também ocorre em intercrescimentos mirmequíticos. O plagioclásio, subédrico a anédrico, encontra-se leve a intensamente sericitizado e localmente saussuritizado. Os cristais de microclina são anédricos a subédricos, por vezes poiquilíticos, e apresentam discretos intercrescimentos micropertíticos, encontrandose fraca a intensamente alterados para argilominerais e sericita. As lamelas de muscovita (Figura 7C) são subédricas a anédricas e apresentam contatos retilíneos a irregulares com plagioclásio e quartzo. Também ocorrem lamelas de muscovita secundária, que exibem bordas corroídas e contêm clorita e finos minerais opacos em seus planos de clivagem, o que sugere que biotita pode ter estado presente como mineral varietal, que foi completamente substituído por esses minerais, restando apenas pseudomorfos.

A rocha foi incipiente a intensamente afetada por alteração hidrotermal. Nas porções mais intensamente hidrotermalizadas, as texturas ígneas originais foram completamente obliteradas (Figuras 7B, 7D e 7E). A alteração incipiente é marcada pela substituição seletiva de minerais primários. Nas porções mais fortemente alteradas, a alteração é pervasiva e evidenciada por agregados de clorita, calcita, muscovita e óxidos de ferro, por vezes associados a cristais de pirita (Figuras 7D e 7E). Vênulas ocorrem localmente e cortam porções da rocha afetadas por alteração pervasiva (Figura 7B).

A rocha foi ainda leve a fortemente afetada por deformação dúctil a rúptil. As porções afetadas por deformação dúctil são caracterizadas pelo desenvolvimento de foliação protomilonítica heterogênea (Figura 7F), definida pela orientação preferencial de lamelas de muscovita e de porfiroclastos amendoados de plagioclásio, microclina e quartzo. Nessas porções, o quartzo apresenta extinção ondulante forte, desenvolve subgrãos, e eventualmente exibe lamelas de deformação, além de compor tramas de cristais recristalizados e estirados, de granulação fina, que exibem contatos poligonais e interlobados. A deformação rúptil é caracterizada por microfraturas em cristais de plagioclásio e feldspato potássico, além de vênulas (Figura 7B). Feições produzidas por deformação rúptil e dúctil coexistem em algumas porções da rocha.

\section{Sienogranito}

É intrusivo em metaconglomerados da Formação Castelo dos Sonhos. Apresenta coloração rosada nas porções mais frescas e exibe tons avermelhados quando alterado (Figuras 8A e 8B).

Ao microscópio (Figuras $8 \mathrm{C}$ a 8F), apresenta textura hipidiomórfica inequigranular e granulação média a grossa (Figura $8 \mathrm{C}$ ). $\mathrm{O}$ quartzo é anédrico, exibe extinção ondulante moderada a forte e apresenta contatos irregulares com plagioclásio e microclina; cristais exibindo contatos poligonais entre si ocorrem localmente. Quartzo também está presente como cristais vermiculares em intercrescimentos mirmequíticos.

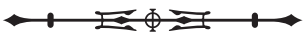




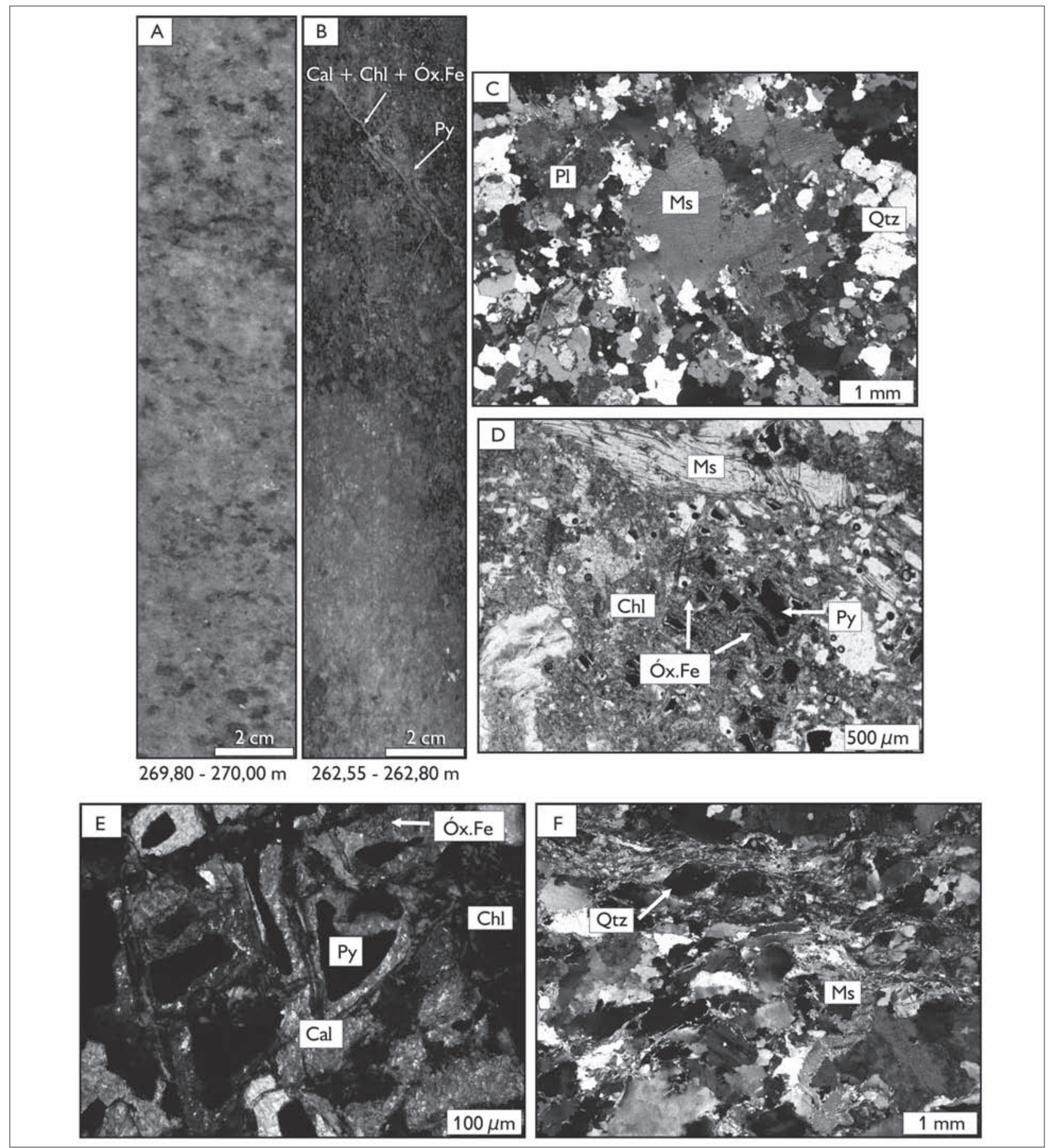

Figura 7. Aspectos macro e microscópicos do MM: A) MM maciço e pouco alterado; B) MM intensamente hidrotermalizado e deformado, cortado por vênula de calcita, clorita e óxidos de ferro, apresentando, ainda, finos cristais de pirita dispersos na porção superior; C) textura granular alotriomórfica; D e E) alteração hidrotermal pervasiva, caracterizada por agregados de clorita, calcita, muscovita e óxidos de ferro, por vezes associados a cristais de pirita; F) porção fortemente deformada do MM: lamelas de muscovita e porfiroclastos amendoados de quartzo definem foliação protomilonítica heterogênea e levemente ondulada. Legendas: MM = muscovita monzogranito; Qtz = quartzo; $\mathrm{Pl}=$ plagioclásio; $\mathrm{Ms}=$ muscovita; $\mathrm{Cal}=$ calcita; $\mathrm{Chl}=$ clorita; Py = pirita; Óx.Fe = óxidos de ferro.

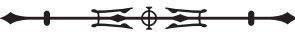




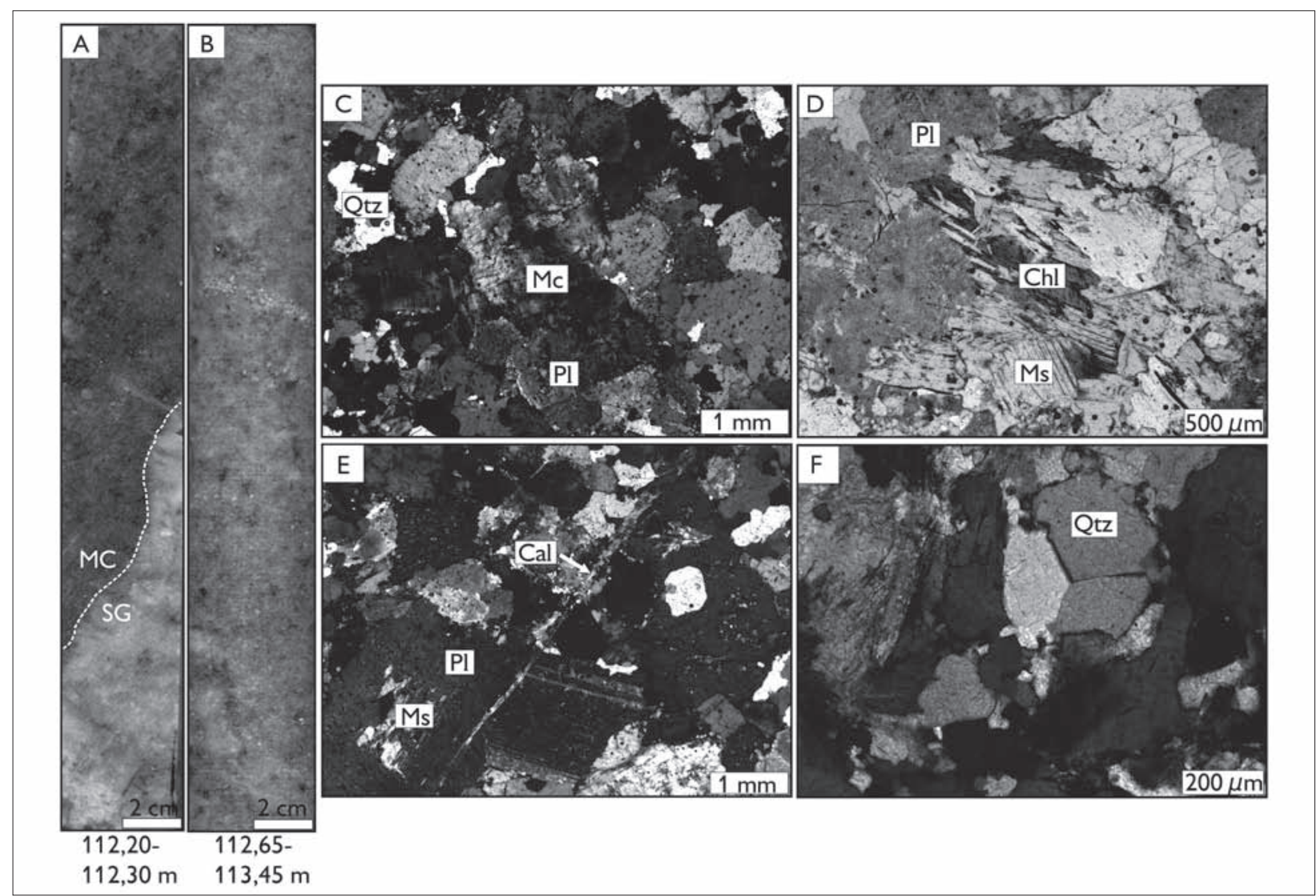

Figura 8. Aspectos macro e microscópicos do SG: A) contato entre SG e metaconglomerado da Formação Castelo dos Sonhos; B) SG maciço e pouco alterado; C) textura granular hipidiomórfica; D) lamelas de muscovita e clorita, provavelmente resultantes de alteração total de biotita primária; E) vênula de calcita (seta) corta cristais de quartzo e cristais de plagioclásio, alterados para sericita/muscovita; F) cristais de quartzo exibindo contatos poligonais. Legendas: SG = sienogranito; $M C=$ metaconglomerado; Qtz = quartzo; Pl = plagioclásio; $\mathrm{Mc}$ = microclina; $\mathrm{Ms}=$ muscovita; Chl = clorita; Cal = calcita.

O plagioclásio, subédrico a anédrico, encontra-se moderada a fortemente sericitizado e/ou argilizado, com alteração local para muscovita (Figura 8E), epidoto e calcita, sendo localmente cortado por vênulas de calcita (Figura 8E). Os cristais de microclina são subédricos a anédricos (Figura 8C), por vezes poiquilíticos, e alguns apresentam intercrescimentos micropertíticos dos tipos filme e mancha. Encontram-se leve a intensamente argilizados e/ou sericitizados, e ocasionalmente exibem extinção ondulante forte e microfraturas. Lamelas de muscovita, que exibem bordas corroídas e contêm clorita e finos minerais opacos em seus planos de clivagem, sugerem que biotita provavelmente esteve presente na rocha como fase varietal, tendo sido totalmente substituída, o que resultou na formação de pseudomorfos (Figura 8D).

A rocha foi pouco afetada por alteração hidrotermal e apresenta texturas ígneas bem preservadas. A alteração hidrotermal manifesta-se principalmente pela substituição seletiva de minerais primários (Figuras 8D e 8E) e, localmente, pela ocorrência de vênulas (Figura 8E).

Feições deformacionais ocorrem apenas localmente. Cristais de quartzo e microclina exibindo extinção ondulante forte e cristais de quartzo que desenvolvem contatos poligonais (Figura 8F) são indicativos de deformação rúptildúctil; já a ocorrência de vênulas (Figura 8E) e microfraturas na microclina e no plagioclásio caracteriza deformação rúptil.

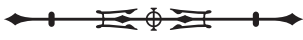




\section{GEOQUÍMICA}

As composições químicas das rochas estudadas são apresentadas na Tabela 2. As amostras analisadas mostraram baixas percentagens $(0,36$ a 1,30\%) de perda ao fogo (PF) e de carbono $(0,02$ a 0,12\%) e enxofre $(<0,01$ a $0,01 \%)$ totais. Embora o número de amostras analisadas não permita uma análise estatística substancial, em nenhum litotipo foi observada correlação entre PF e $\mathrm{K}_{2} \mathrm{O}$ ou $\mathrm{Ba} / \mathrm{Rb}$ (Figuras 9A e 9B), o que indica ausência de mobilidade desses componentes. De modo geral, diagramas Zrversus La, Ce e Eu (Figuras 9C, 9D e 9E) também mostraram que não há mobilidade significativa dos elementos terras raras (ETR). $\bigcirc$ comportamento diferente de algumas amostras pode indicar que se trata de rochas pertencentes a unidades distintas e/ou que responderam de modo diferente ao tipo e intensidade da alteração que as afetou.

Há diferenças significativas em relação ao conteúdo de $\mathrm{SiO}_{2}$ (Tabela 2). DP e BG apresentaram os teores mais baixos, variando de 64,54 a 67,49\% (exceto uma amostra de $\mathrm{BG}$, com teor de $\mathrm{SiO}_{2}$ de $\left.74,03 \%\right)$, enquanto $\mathrm{BM}$, MM e SG mostraram os teores mais elevados, variando de 72,30 a 76,40\%. O aumento no conteúdo de sílica é acompanhado pelo decréscimo dos teores de $\mathrm{TiO}_{2}$, $\mathrm{Fe}_{2} \mathrm{O}_{3} \mathrm{t}, \mathrm{MgO}$ e $\mathrm{CaO}$, que são mais elevados em DP e BG e consideravelmente mais baixos em BM, MM e SG. Por outro lado, o aumento da sílica reflete aumento nos teores de $\mathrm{K}_{2} \mathrm{O}$, significativamente mais elevados em $\mathrm{BM}$, MM e SG e mais baixos em DP e BG.

Tabela 2. Composição química das rochas intrusivas na Formação Castelo dos Sonhos. Legendas: PF = perda ao fogo; nd = não determinado; $\mathrm{N}$ = razão normalizada ao condrito; $\mathrm{DP}=$ dacito porfirítico; $\mathrm{BG}=$ biotita granodiorito; $\mathrm{BM}=$ biotita monzogranito; $\mathrm{MM}$ = muscovita monzogranito; SG = sienogranito.

(Continua)

\begin{tabular}{|c|c|c|c|c|c|c|c|c|c|c|}
\hline Rocha & \multicolumn{3}{|c|}{ DP } & \multicolumn{3}{|c|}{ BG } & \multirow{2}{*}{$\begin{array}{c}\text { BM } \\
\text { EK-79 } \\
51,30\end{array}$} & \multirow{2}{*}{$\begin{array}{c}\text { MM } \\
\text { EK-01 } \\
253,50\end{array}$} & \multicolumn{2}{|c|}{ SG } \\
\hline Amostra & $\begin{array}{c}\text { EK-2 } \\
418,50\end{array}$ & $\begin{array}{c}\text { EK-2 } \\
424,15\end{array}$ & $\begin{array}{c}\text { EK-2 } \\
430,70\end{array}$ & $\begin{array}{l}\text { EK-48 } \\
56,05\end{array}$ & $\begin{array}{l}\text { EK-48 } \\
58,90\end{array}$ & $\begin{array}{l}\text { EK-48 } \\
63,20\end{array}$ & & & $\begin{array}{c}\text { EK-01 } \\
265,10\end{array}$ & $\begin{array}{l}\text { EK-48 } \\
112,65\end{array}$ \\
\hline $\mathrm{SiO}_{2}$ (\% peso) & 65,04 & 65,37 & 64,54 & 74,03 & 67,49 & 64,71 & 72,30 & 75,80 & 76,40 & 75,34 \\
\hline $\mathrm{Al}_{2} \mathrm{O}_{3}$ & 14,74 & 14,39 & 14,51 & 15,19 & 17,02 & 17,75 & 14,90 & 12,90 & 11,90 & 13,00 \\
\hline $\mathrm{Fe}_{2} \mathrm{O}_{3}$ & 6,00 & 5,39 & 5,76 & 3,09 & 4,38 & 4,15 & 2,76 & 2,62 & 1,94 & 1,32 \\
\hline $\mathrm{Na}_{2} \mathrm{O}$ & 3,11 & 2,55 & 3,08 & 4,10 & 4,77 & 4,58 & 4,20 & 3,02 & 3,08 & 2,81 \\
\hline $\mathrm{CaO}$ & 3,45 & 3,46 & 3,73 & 2,14 & 3,19 & 3,48 & 0,72 & 0,37 & 0,35 & 0,68 \\
\hline $\mathrm{K}_{2} \mathrm{O}$ & 3,10 & 3,64 & 3,55 & 1,94 & 1,94 & 2,88 & 4,17 & 4,63 & 4,08 & 5,50 \\
\hline $\mathrm{MgO}$ & 1,77 & 1,64 & 1,84 & 0,79 & 0,96 & 0,91 & 0,42 & 0,63 & 0,32 & 0,10 \\
\hline $\mathrm{MnO}$ & 0,15 & 0,14 & 0,11 & 0,06 & 0,08 & 0,08 & 0,05 & 0,04 & 0,03 & 0,04 \\
\hline $\mathrm{P}_{2} \mathrm{O}_{5}$ & 0,15 & 0,15 & 0,15 & 0,04 & 0,08 & 0,15 & 0,16 & 0,03 & 0,04 & 0,01 \\
\hline $\mathrm{TiO}_{2}$ & 0,60 & 0,54 & 0,53 & 0,35 & 0,48 & 0,44 & 0,25 & 0,12 & 0,08 & 0,04 \\
\hline $\mathrm{Cr}_{2} \mathrm{O}_{3}$ & $<0,01$ & $<0,01$ & $<0,01$ & $<0,01$ & $<0,01$ & $<0,01$ & $<0,01$ & 0,03 & $<0,01$ & $<0,01$ \\
\hline PF & 1,30 & 0,62 & 1,15 & 0,76 & 0,81 & 0,47 & 0,66 & 0,82 & 0,50 & 0,36 \\
\hline Total & 99,39 & 97,90 & 98,95 & 102,51 & 101,2 & 99,61 & 100,59 & 101,01 & 98,72 & 99,20 \\
\hline C total & nd & nd & nd & 0,03 & 0,05 & 0,02 & 0,03 & 0,12 & 0,03 & 0,02 \\
\hline S total & nd & nd & nd & $<0,01$ & 0,01 & $<0,01$ & $<0,01$ & 0,01 & 0,01 & $<0,01$ \\
\hline $\mathrm{Ba}$ (ppm) & 678 & 815 & 736 & 1877 & 1949 & 2293 & 1330 & 184 & 143 & 479 \\
\hline $\mathrm{Be}$ & 2,2 & 2,8 & 2,2 & 2,0 & 1,2 & 1,3 & 1,4 & 3,5 & 3,7 & 1,3 \\
\hline Cs & 3,38 & 7,29 & 4,51 & 1,63 & 1,46 & 0,67 & 0,94 & 1,09 & 1,32 & 1,2 \\
\hline Ga & 19,5 & 19,7 & 19,3 & 15 & 19,4 & 20,4 & 15,1 & 24,0 & 16,9 & 15,4 \\
\hline
\end{tabular}


Tabela 2.

\begin{tabular}{|c|c|c|c|c|c|c|c|c|c|c|}
\hline \multirow{2}{*}{$\begin{array}{c}\text { Rocha } \\
\text { Amostra }\end{array}$} & \multicolumn{3}{|c|}{ DP } & \multicolumn{3}{|c|}{$B G$} & \multirow{2}{*}{$\begin{array}{c}\text { BM } \\
\text { EK-79 } \\
51,30\end{array}$} & \multirow{2}{*}{$\begin{array}{c}M M \\
E K-01 \\
253,50\end{array}$} & \multicolumn{2}{|c|}{ SG } \\
\hline & $\begin{array}{c}\text { EK-2 } \\
418,50\end{array}$ & $\begin{array}{c}\text { EK-2 } \\
424,15\end{array}$ & $\begin{array}{c}\text { EK-2 } \\
430,70\end{array}$ & $\begin{array}{l}\text { EK-48 } \\
56,05\end{array}$ & $\begin{array}{l}\text { EK-48 } \\
58,90\end{array}$ & $\begin{array}{l}\text { EK-48 } \\
63,20\end{array}$ & & & $\begin{array}{c}\text { EK-01 } \\
265,10\end{array}$ & $\begin{array}{l}\text { EK-48 } \\
112,65\end{array}$ \\
\hline $\mathrm{Hf}$ & 5,31 & 5,25 & 4,88 & 6,18 & 6,97 & 7,06 & 4,26 & 2,67 & 2,07 & 2,1 \\
\hline $\mathrm{Nb}$ & 11,99 & 11,73 & 10,82 & 7,82 & 3,67 & 2,98 & 7,13 & 18,04 & 13,38 & 1,54 \\
\hline $\mathrm{Rb}$ & 149,8 & 195,6 & 175,8 & 65,3 & 66,4 & 75,9 & 93,2 & 238,7 & 216,6 & 170,4 \\
\hline $\mathrm{Sn}$ & 2,7 & 2,5 & 3,2 & 2,5 & 0,8 & 1,0 & 0,7 & 7,3 & 2,8 & 0,4 \\
\hline $\mathrm{Sr}$ & 373,8 & 400,8 & 426,1 & 613,5 & 915,5 & 973,7 & 328,8 & 37,5 & 40,4 & 134,1 \\
\hline $\mathrm{Ta}$ & 1,04 & 1,12 & 1,11 & 1,11 & $<0,05$ & $<0,05$ & 0,06 & 2,65 & 2,53 & $<0,05$ \\
\hline Th & 17,1 & 17,9 & 19,9 & 10,8 & 11,7 & 7,5 & 5,9 & 13,2 & 12,5 & 9,3 \\
\hline$\cup$ & 4,69 & 5,05 & 5,38 & 1,16 & 0,91 & 1,01 & 0,84 & 5,67 & 7,77 & 7,97 \\
\hline W & 1,9 & 1,1 & 3,3 & 4,2 & $<0,1$ & $<0,1$ & 0,4 & 2,7 & 2,2 & $<0,1$ \\
\hline$Y$ & 22,98 & 21,58 & 21,31 & 12,52 & 14,44 & 11,58 & 11,18 & 30,26 & 27,25 & 18,95 \\
\hline $\mathrm{Zr}$ & 197,6 & 190 & 169,8 & 256,4 & 346,3 & 343,2 & 167,9 & 62,8 & 35,8 & 44,8 \\
\hline Co & 12,8 & 12,8 & 13,2 & 9,6 & 10,6 & 6,3 & 2,4 & 2,0 & 1,6 & 2,3 \\
\hline $\mathrm{Cu}$ & 6,0 & 37 & 23 & $<5,0$ & 8,0 & 7,0 & 6,0 & 18,0 & 6,0 & $<5,0$ \\
\hline $\mathrm{Ni}$ & 13 & 13 & 16 & 21 & $<5,0$ & $<5,0$ & $<5,0$ & $<5,0$ & $<5,0$ & $<5,0$ \\
\hline $\mathrm{La}$ & 41,7 & 41,9 & 42,4 & 56,6 & 60,7 & 45,9 & 40,8 & 16,8 & 12,8 & 8,8 \\
\hline $\mathrm{Ce}$ & 81,5 & 82,4 & 82,9 & 95,1 & 110,3 & 88,3 & 58,8 & 32,1 & 24,2 & 19,0 \\
\hline $\operatorname{Pr}$ & 9,19 & 9,2 & 9,14 & 9,47 & 11,98 & 8,8 & 5,75 & 3,31 & 2,65 & 2,61 \\
\hline $\mathrm{Nd}$ & 33,7 & 32,7 & 33 & 33,2 & 42,5 & 32,5 & 20,5 & 11,4 & 9,4 & 9,5 \\
\hline $\mathrm{Sm}$ & 5,7 & 5,8 & 5,5 & 4,4 & 5,6 & 4,4 & 3,5 & 3,1 & 2,6 & 1,9 \\
\hline Eu & 1,24 & 1,14 & 1,19 & 1,09 & 1,45 & 1,27 & 0,8 & 0,23 & 0,22 & 0,34 \\
\hline $\mathrm{Gd}$ & 4,69 & 4,67 & 4,2 & 3,26 & 4,52 & 3,14 & 2,62 & 3,24 & 3,31 & 2,52 \\
\hline $\mathrm{Tb}$ & 0,68 & 0,67 & 0,62 & 0,47 & 0,5 & 0,37 & 0,35 & 0,63 & 0,69 & 0,42 \\
\hline Dy & 3,87 & 3,6 & 3,26 & 2,27 & 2,9 & 2,09 & 1,93 & 4,25 & 4,57 & 2,91 \\
\hline $\mathrm{Ho}$ & 0,77 & 0,70 & 0,66 & 0,54 & 0,55 & 0,4 & 0,39 & 0,91 & 0,97 & 0,65 \\
\hline $\mathrm{Er}$ & 2,05 & 1,89 & 2,15 & 1,38 & 1,52 & 1,26 & 1,15 & 2,84 & 3,16 & 1,96 \\
\hline $\mathrm{Tm}$ & 0,35 & 0,34 & 0,33 & 0,3 & 0,21 & 0,18 & 0,16 & 0,45 & 0,5 & 0,31 \\
\hline Yb & 2,2 & 2,1 & 1,9 & 1,4 & 1,3 & 1,3 & 1,1 & 3,1 & 3,5 & 2,0 \\
\hline $\mathrm{Lu}$ & 0,34 & 0,29 & 0,28 & 0,32 & 0,21 & 0,22 & 0,16 & 0,44 & 0,49 & 0,3 \\
\hline Eu/Eu* & 0,7 & 0,7 & 0,8 & 0,9 & 0,9 & 1,0 & 0,8 & 0,2 & 0,2 & 0,5 \\
\hline LaN/YbN & 12,8 & 13,5 & 15,0 & 27,3 & 31,5 & 23,8 & 25,0 & 3,7 & 2,5 & 3,0 \\
\hline $\mathrm{LaN} / \mathrm{SmN}$ & 4,6 & 4,5 & 4,8 & 8,1 & 6,8 & 6,6 & 7,3 & 3,4 & 3,1 & 2,9 \\
\hline CeN/YbN & 9,6 & 10,1 & 11,3 & 17,6 & 21,9 & 17,6 & 13,8 & 2,7 & 1,8 & 2,5 \\
\hline $\mathrm{CeN} / \mathrm{SmN}$ & 3,5 & 3,4 & 3,6 & 5,2 & 4,8 & 4,8 & 4,1 & 2,5 & 2,2 & 2,4 \\
\hline EuN/YbN & 1,6 & 1,5 & 1,8 & 2,2 & 3,2 & 2,8 & 2,1 & 0,2 & 0,2 & 0,5 \\
\hline ETR Total & 188,0 & 187,4 & 187,5 & 209,8 & 244,2 & 190,1 & 138,0 & 82,8 & 69,1 & 53,2 \\
\hline
\end{tabular}



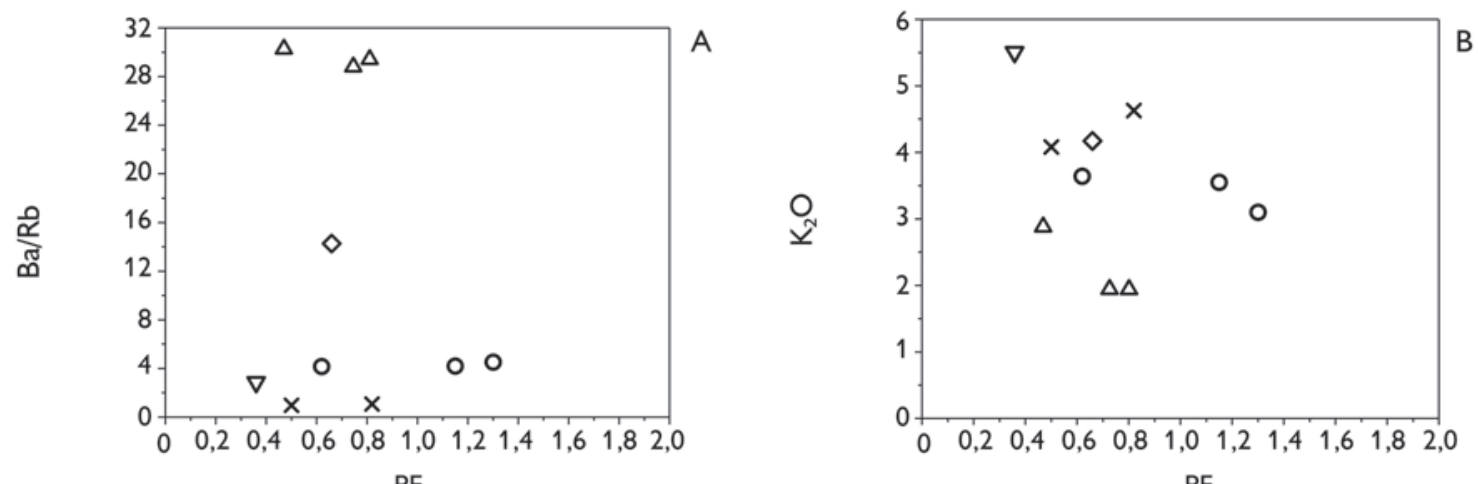

$\mathrm{PF}$
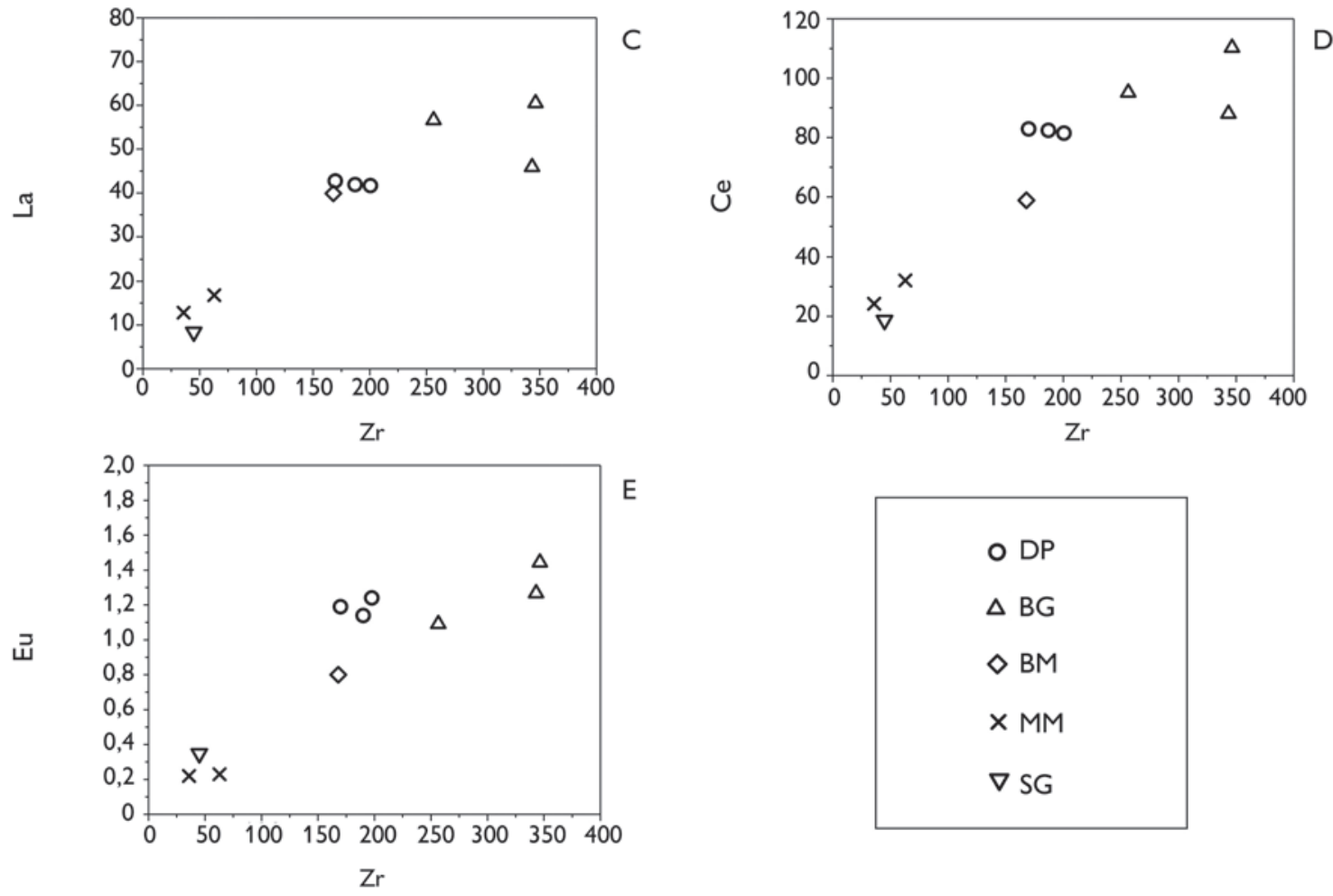

$E$

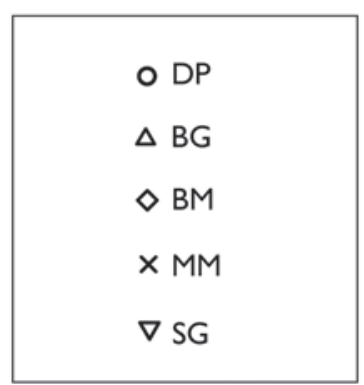

Figura 9. Diagramas de mobilidade Ba/Rb versus LOI (A), $\mathrm{K}_{2}$ O versus LOI (B), La versus Zr (C); Ceversus Zr (D) e Eu versus Zr (E). Legendas: $\mathrm{DP}=$ dacito porfirítico; $\mathrm{BG}=$ biotita granodiorito; $\mathrm{BM}=$ biotita monzogranito; $\mathrm{MM}=$ muscovita monzogranito; $\mathrm{SG}=$ sienogranito.

O índice de Shand (Figura 10A) revelou o caráter fracamente peraluminoso de BG, BM e SG, enquanto o MM mostrou-se consideravelmente peraluminoso e o DP essencialmente metaluminoso.

Nos diagramas de discriminação tectônica (Figuras 10B a 10D), todos os granitoides estudados mostraram-se compatíveis com ambiente de arco vulcânico e também plotaram no campo dos granitos pós-colisonais.

O DP apresenta alto conteúdo total de ETR (187,4188,0 ppm), moderado fracionamento de elementos terras raras pesados (ETRP) [(La/Yb)n de 12,8 a 15,0] e discretas anomalias negativas de $\mathrm{Eu}\left(\mathrm{Eu} / \mathrm{Eu}^{*}=0,7\right.$ a 0,8; 
Tabela 2; Figura 11A). Nos diagramas multielementares, destaca-se acentuada anomalia negativa de $\mathrm{Nb}$ e anomalias menos proeminentes de $\mathrm{Ba}, \mathrm{P}$ e $\mathrm{Ti}$, negativas, e de $\mathrm{Pb}$, positiva (Figura 11B).

O BG apresentou o maior conteúdo total de ETR (190,1-244,2 ppm) e, comparativamente ao DP, mostra fracionamento mais acentuado de ETRP $[(\mathrm{La} / \mathrm{Yb}) \mathrm{n}$ de 23,8 a 31,5] e anomalias negativas de Eu praticamente inexistentes ( $E u / E u^{*}=0,9$ a 1,0) (Tabela 2; Figura 12A). O BG distingue-se ainda do DP por apresentar anomalias negativas mais pronunciadas de $\mathrm{Nb}$ e $\mathrm{P}$, além de discreta anomalia positiva de Ba (Figura 12B).
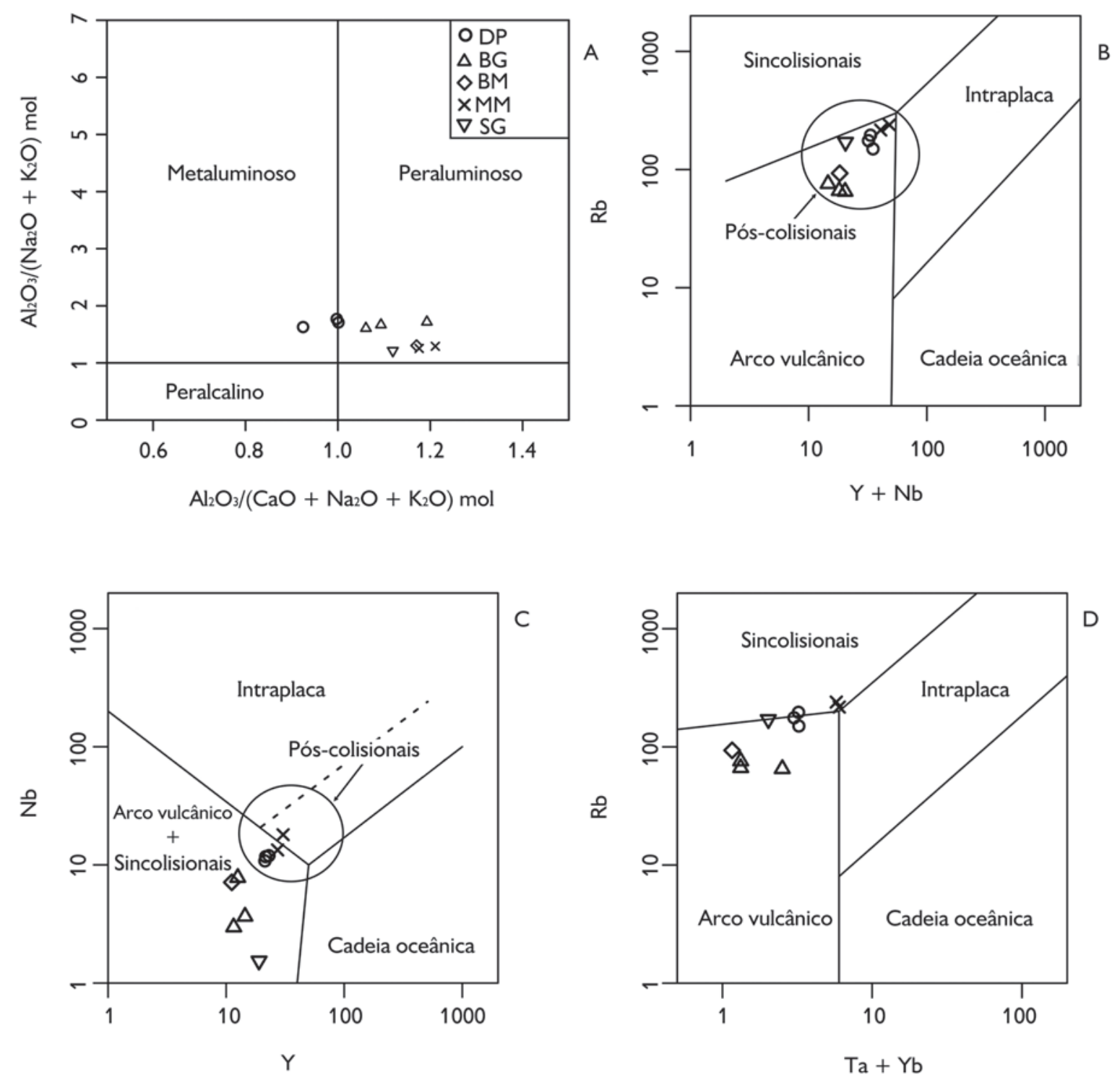

Figura 10. Diagrama $\mathrm{Al}_{2} \mathrm{O}_{3} /\left(\mathrm{CaO}+\mathrm{Na}_{2} \mathrm{O}+\mathrm{K}_{2} \mathrm{O}\right)$ versus $\mathrm{Al}_{2} \mathrm{O}_{3} /\left(\mathrm{Na}_{2} \mathrm{O}+\mathrm{K}_{2} \mathrm{O}\right)$, de Shand (1943) (A); diagramas de discriminação tectônica de Pearce et al. (1984): Rb versus $\mathrm{Y}+\mathrm{Nb}$ (B), Nb versus $\mathrm{Y}(\mathrm{C})$ e Rb versus Ta $+\mathrm{Yb}(\mathrm{D})$.

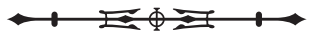




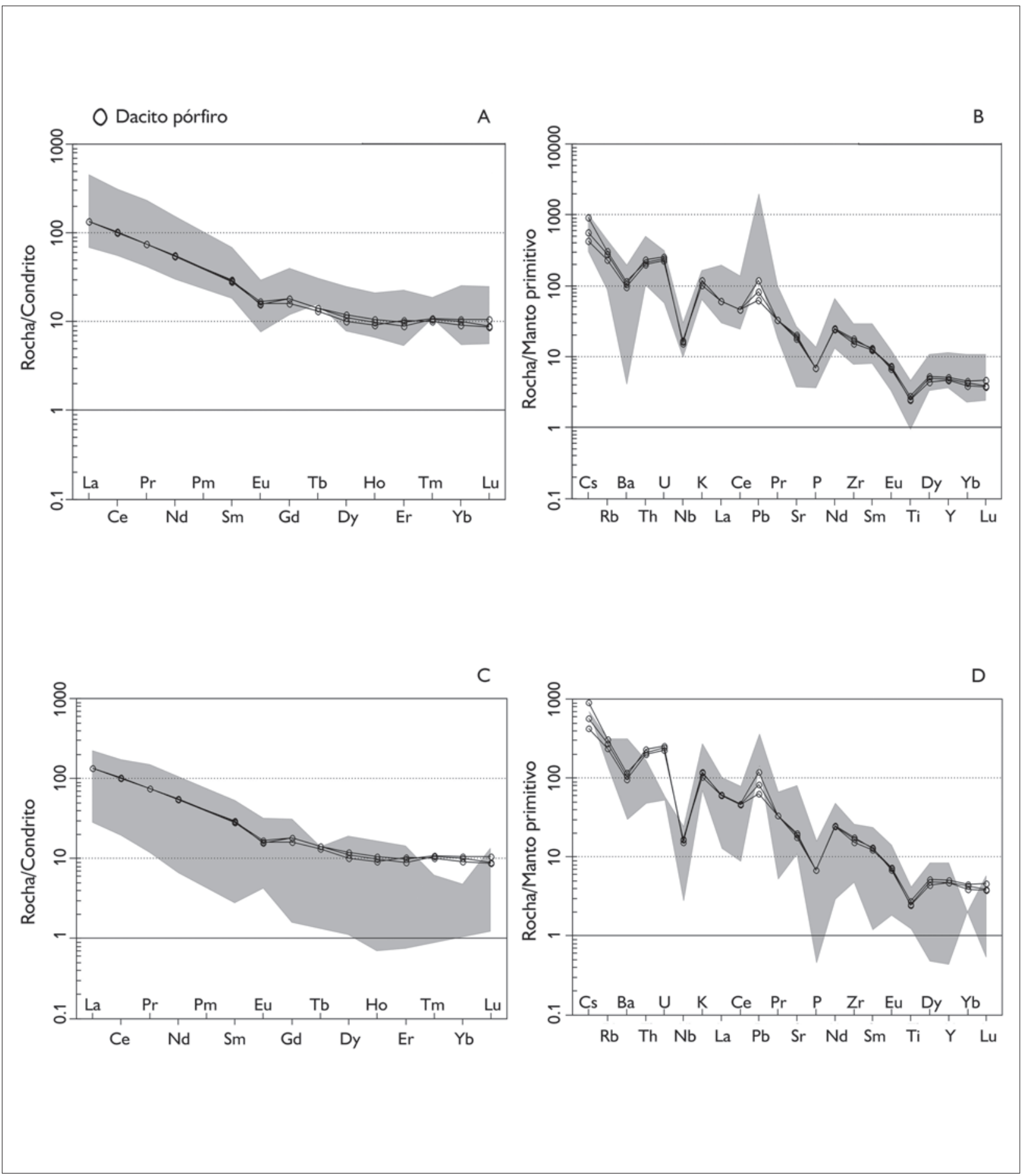

Figura 11. Padrão dos elementos terras raras (normalizados ao condrito de Boynton, 1984) e diagramas multielementares (normalizados para o manto primitivo de Sun \& McDonough, 1989), representativos do DP em relação a unidades do Domínio Tapajós (áreas sombreadas): A e B) DP comparado à Suíte Intrusiva Creporizão (Vasquez et al., 2002; Coutinho et al., 2008); C e D) DP comparado ao Complexo Cuiú-Cuiú (Vasquez et al., 2002; Coutinho et al., 2008).

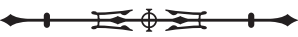




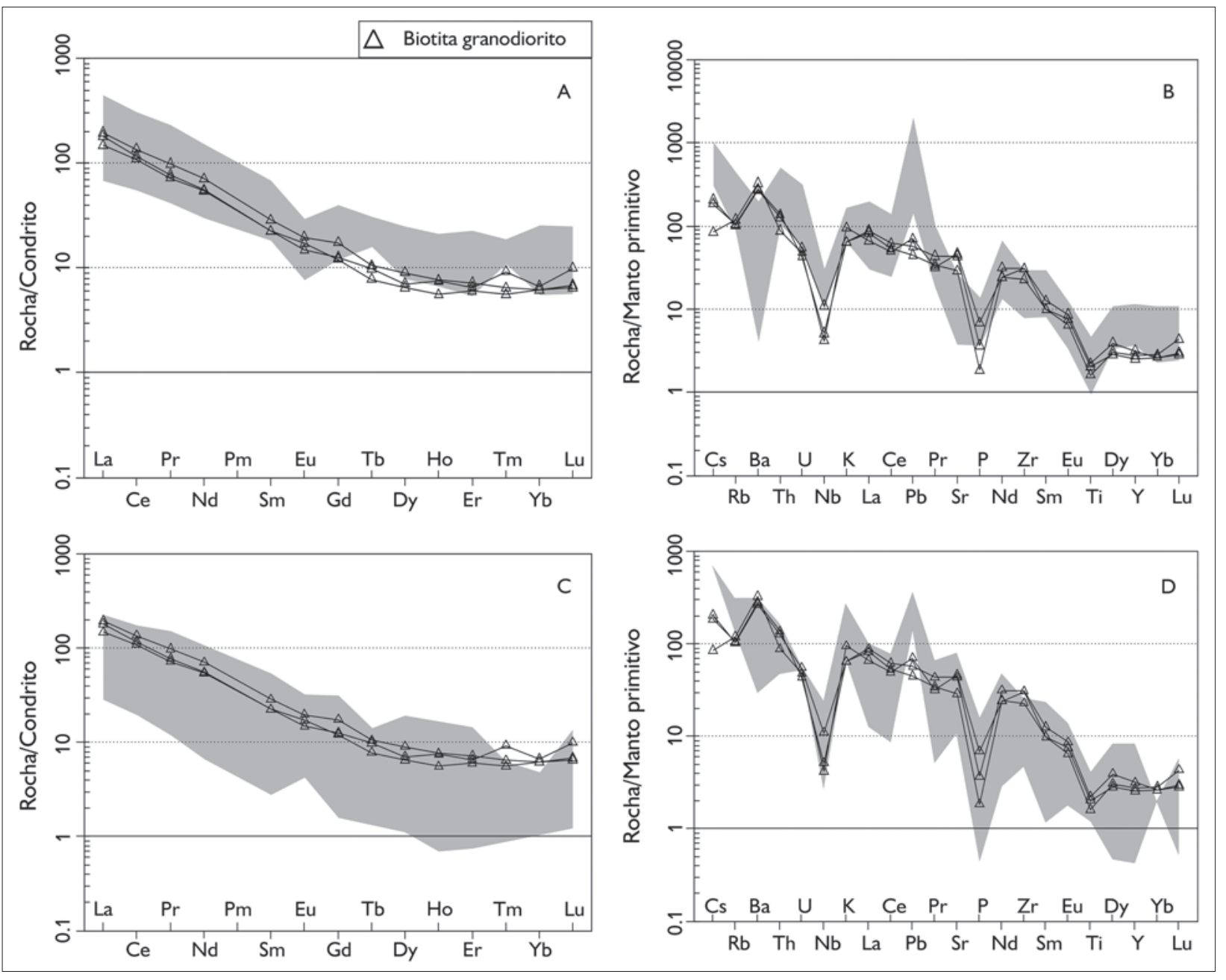

Figura 12. Padrão dos elementos terras raras (normalizados ao condrito de Boynton, 1984) e diagramas multielementares (normalizados para o manto primitivo de Sun \& McDonough, 1989), representativos do BG em relação a unidades do Domínio Tapajós (áreas sombreadas): A e B) BG comparado à Suíte Intrusiva Creporizão (Vasquez et al., 2002; Coutinho et al., 2008); C e D) BG comparado ao Complexo Cuiú-Cuiú (Vasquez et al., 2002; Coutinho et al., 2008).

O BM apresenta moderado conteúdo total de ETR (138 ppm) e mostra um padrão de ETR muito semelhante ao do BG, com importante fracionamento de ETRP [(La/Yb)n = 25], e pequena anomalia negativa de Eu (Eu/Eu* = 0,8) (Tabela 2; Figura 13A). Entretanto, o BM distingue-se do BG por apresentar discretas anomalias positivas de $\mathrm{Ke} \mathrm{Pb}$, e anomalia negativa bem menos acentuada de P (Figura 13B).

O conteúdo total de ETR do MM (69,1-82,8 ppm) é significativamente mais baixo do que o dos três litotipos anteriormente apresentados, dos quais também se distingue por seu padrão de ETR 'asa de gaivota', marcado por profunda anomalia negativa de $\mathrm{Eu}\left(\mathrm{Eu} / \mathrm{Eu}^{*}=0,2\right)$, por significativo fracionamento de ETRL $[(\mathrm{La} / \mathrm{Yb}) \mathrm{n}$ de 2,5 a 3,7] e enriquecimento em ETRP, estes últimos dispondo-se sub-horizontalmente (Tabela 2; Figura 14A). Além disso, o MM mostra um padrão geral mais enriquecido em elementos de raio iônico grande (LILE), em relação aos de alta carga iônica (HFSE) (Figura 14B). 

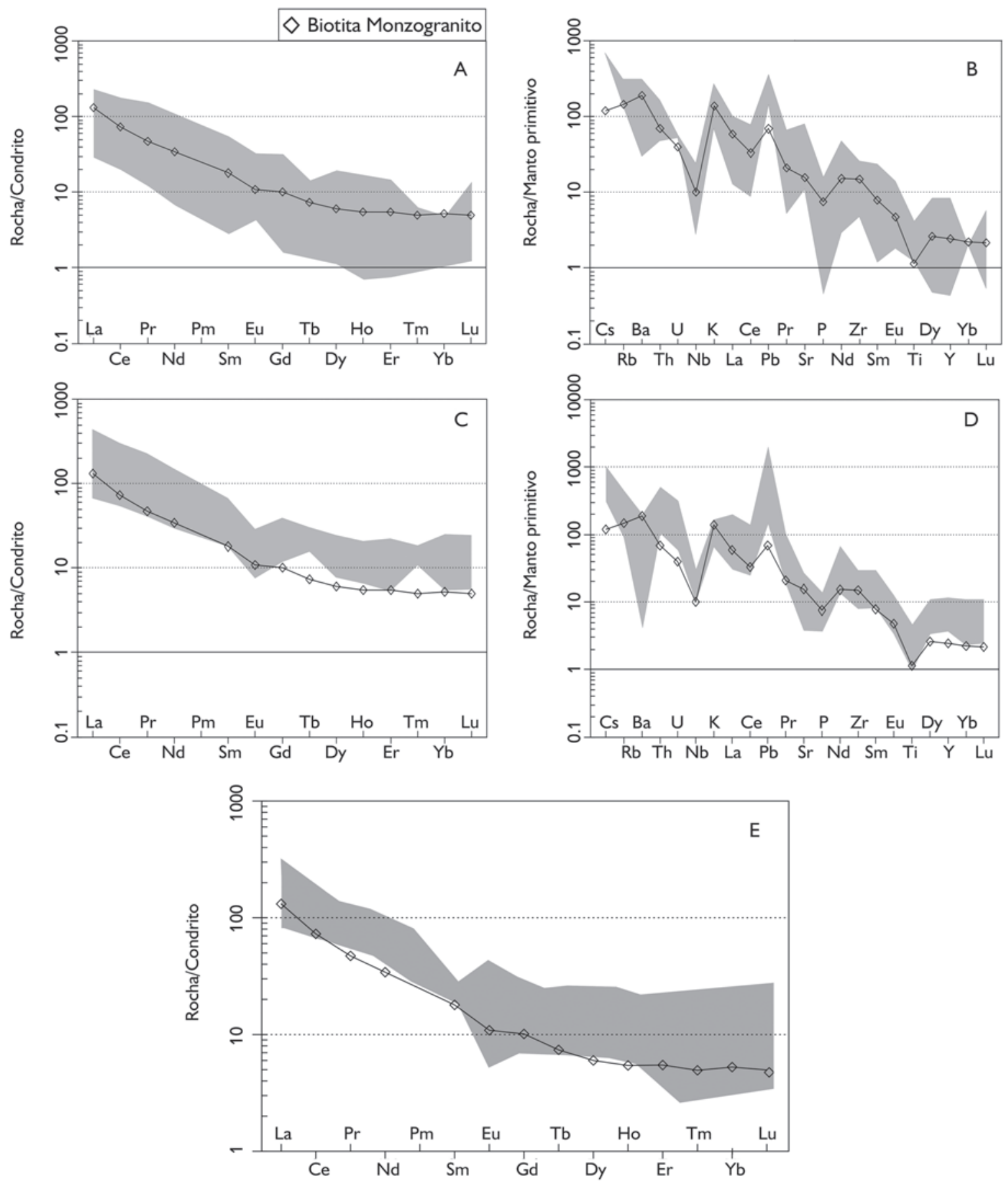

Figura 13. Padrão dos elementos terras raras (normalizados ao condrito de Boynton, 1984) e diagramas multielementares (normalizados para o manto primitivo de Sun \& McDonough, 1989), representativos do BM em relação a unidades do Domínio Tapajós (áreas sombreadas): A e B) BM comparado ao Complexo Cuiú-Cuiú (Vasquez et al., 2002; Coutinho et al., 2008); C e D) BM comparado à Suíte Intrusiva Creporizão (Vasquez et al., 2002; Coutinho et al., 2008); E) BM comparado à Suíte Intrusiva Tropas (Santos et al., 2004).

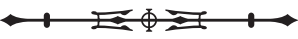




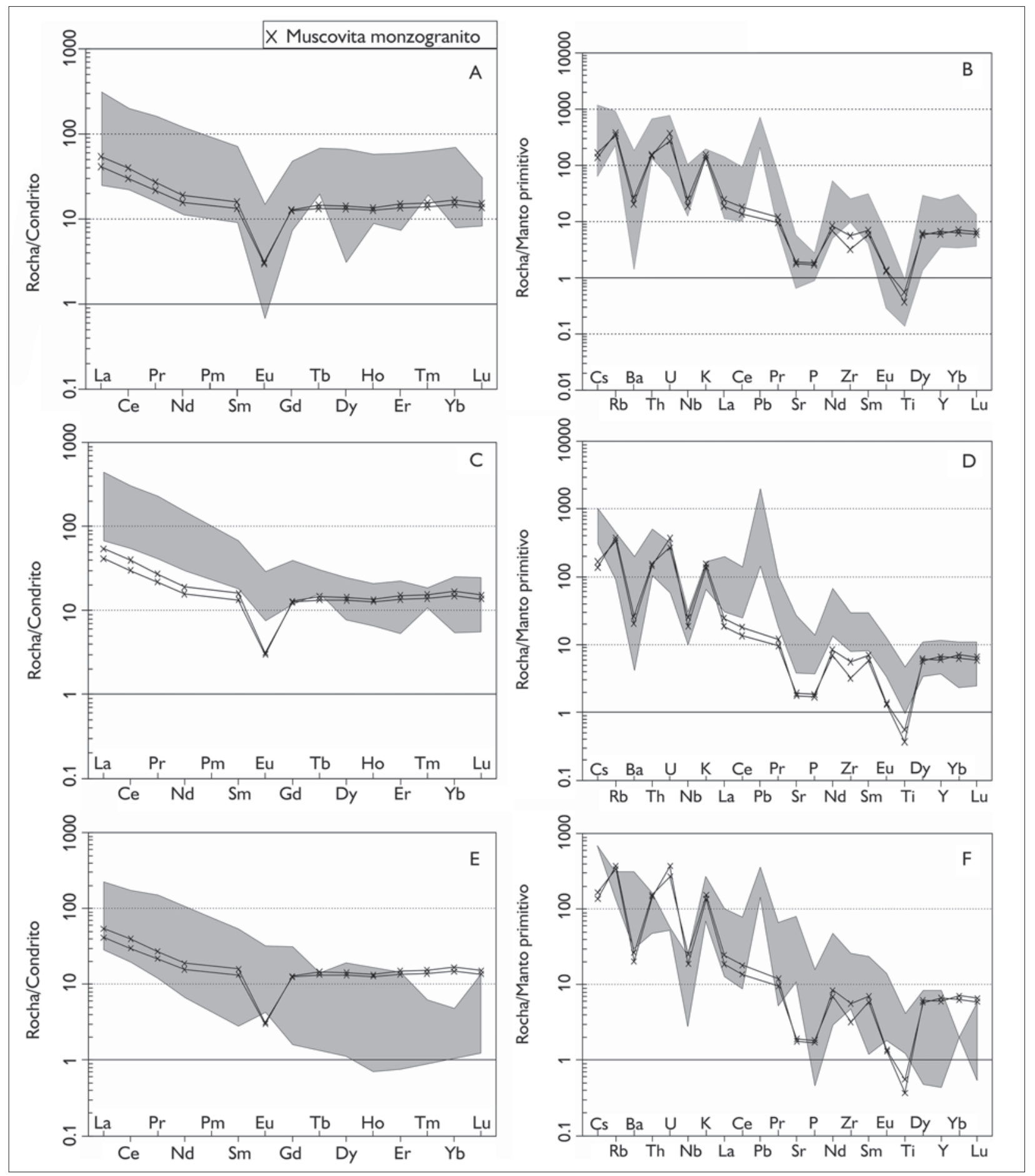

Figura 14. Padrão dos elementos terras raras (normalizados ao condrito de Boynton, 1984) e diagramas multielementares (normalizados para o manto primitivo de Sun \& McDonough, 1989), representativos do MM em relação a unidades do Domínio Tapajós (áreas sombreadas): A e B) MM comparado à Suíte Intrusiva Maloquinha (Vasquez et al., 2002; Coutinho et al., 2008); C e D) MM comparadoà Suíte Intrusiva Creporizão (Vasquez et al., 2002; Coutinho et al., 2008); E e F) MM comparado ao Complexo Cuiú-Cuiú (Vasquez et al., 2002; Coutinho et al., 2008). 
OSG apresentou o mais baixo conteúdo total de ETR (53,2 ppm), mostrando um padrão de ETR semelhante ao MM, também com significativo fracionamento de ETRL $[(\mathrm{La} / \mathrm{Yb}) \mathrm{n}=3,0]$ e a mesma disposição sub-horizontal dos ETRP, embora com enriquecimento mais discreto em ETRP e anomalia negativa de Eu menos profunda (Eu/Eu* $=0,5)$ (Tabela 2; Figura 15A). O SG apresenta também similaridades com o MM em relação ao enriquecimento em LILE e empobrecimento em HFSE, mas se mostra mais enriquecido em $\mathrm{Ba}$ e $\mathrm{Pb}$, e mais empobrecido em $\mathrm{Nb}$ e $\mathrm{P}$ do que o MM (Figura 15B).

\section{GEOCRONOLOGIA U-Pb}

Os litotipos estudados foram datados pelos métodos LAICP-MS (dacito porfirítico) e SHRIMP (biotita granodiorito, biotita monzogranito e muscovita monzogranito). O sienogranito não foi datado. Os resultados analíticos das amostras analisadas são evidenciados nas Tabelas 3 e 4.

\section{Dacito porfirítico}

Os cristais de zircão da amostra EK-02 418,50 (Figura 16A) são incolores a levemente amarelados, alguns ricos em fraturas e/ou inclusões. Em geral, são idiomórficos a subdiomórficos e exibem formas prismáticas alongadas ou curtas, com terminações mono ou bipiramidais; formas elipsoidais e arredondadas a subarredondadas são menos comuns. Em imagem de elétrons retroespalhados, todos os cristais apresentam zoneamento oscilatório ígneo fino a largo ou difuso, geralmente truncado ou cortado por fraturas. Alguns exemplares apresentam bordas com fraturas radiais, geradas possivelmente durante expansão associada ao processo local de metamictização. Não foi possível determinar a idade destas bordas, devido ao elevado conteúdo de $\mathrm{Pb}$ comum. Apenas em um cristal foi identificado núcleo ovoide, aparentemente sem zoneamento, sobrecrescido por bordas zonadas e intensamente fraturadas.

A análise de 57 pontos em 51 cristais gerou um único grupo de dados (Tabela 3), distribuídos ao longo

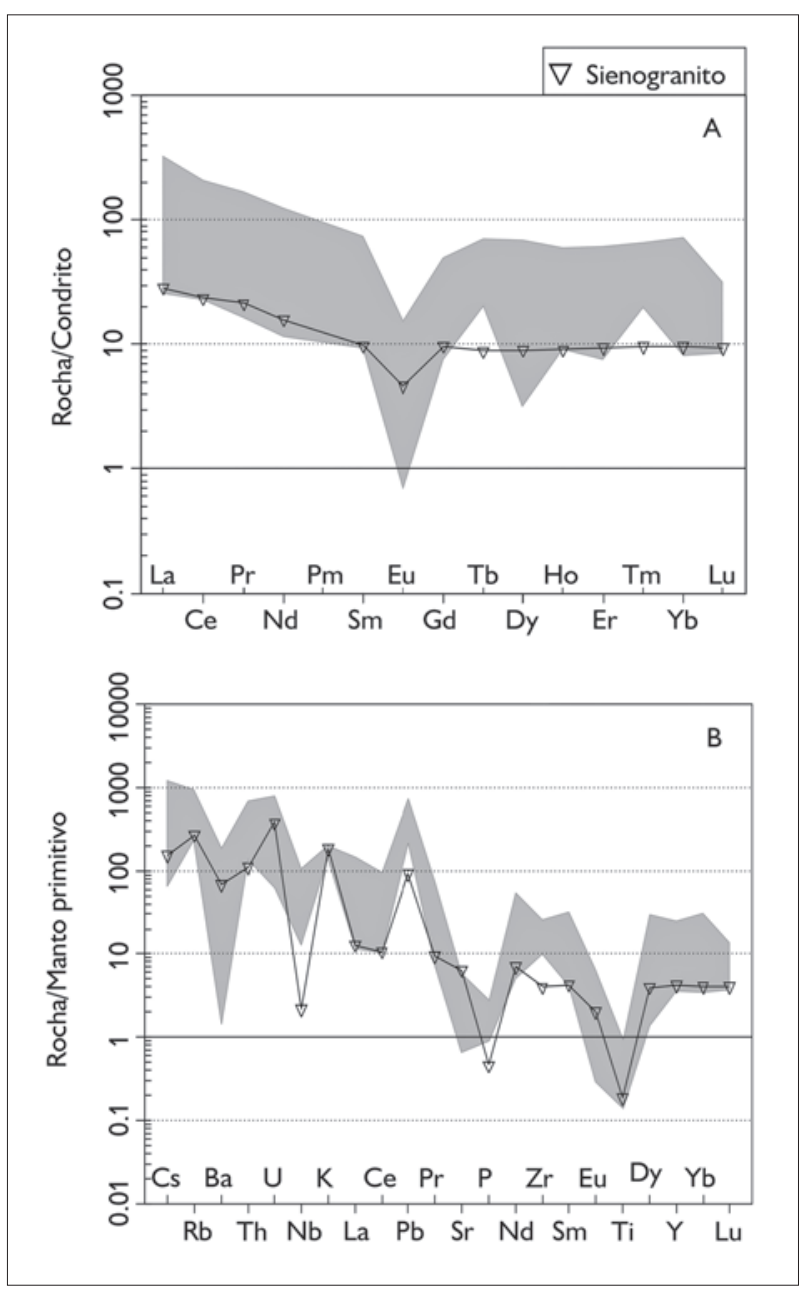

Figura 15. Padrão dos elementos terras raras (normalizados ao condrito de Boynton, 1984) e diagramas multielementares (normalizados para o manto primitivo de Sun \& McDonough, 1989), representativos do SG em relação a unidades do Domínio Tapajós (áreas sombreadas): A e B) SG comparado à Suíte Intrusiva Maloquinha (Vasquez et al., 2002; Coutinho et al., 2008).

de uma discórdia cujo intercepto superior secciona a concórdia em 2011 = $6 \mathrm{Ma}$ (MSDW=0,78; Figura 16B) e o intercepto inferior em $61 \pm 210 \mathrm{Ma}$. Parte dos resultados apresentou considerável discordância reversa e não foi possível fazer qualquer associação com as variações do zoneamento ou localização do ponto. Recálculo feito com apenas quatro cristais concordantes $(<1 \%$ de discordância) e com razões isotópicas similares forneceu idade concordante de $2011 \pm 7$ Ma (MSWD = 0,081; 


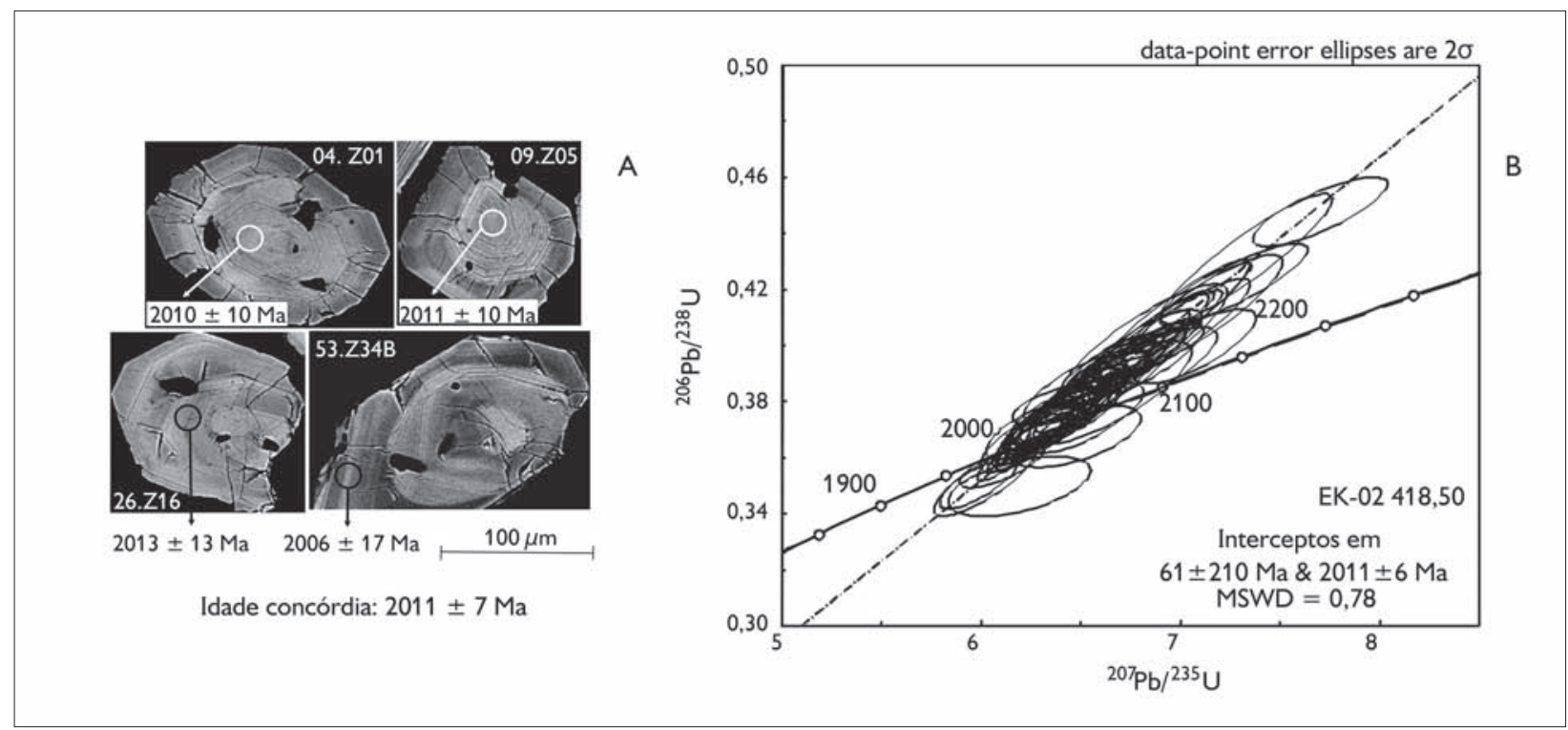

Figura 16. A) Imagens de elétrons retroespalhados representativas de cristais de zircão do dacito porfirítico, com a indicação dos pontos analisados (círculos), as idades aparentes ${ }^{207} \mathrm{~Pb} /{ }^{206} \mathrm{~Pb}$ e a idade concórdia fornecida pelos quatro cristais destacados; B) diagrama discórdia mostrando idade de intercepto superior, calculada com base em 57 pontos analisados em 51 cristais (explicações no texto).

Figura 16A), idêntica, dentro dos limites de erro analítico, à obtida pelo intercepto, ambas representando a idade de cristalização da rocha. O elevado erro analítico atrelado à idade de $61 \pm 210$ Ma compromete a avaliação de seu significado geológico, o mais provável é que reflita perda de $\mathrm{Pb}$ recente.

\section{Biotita granodiorito}

Os cristais de zircão da amostra EK-48 55,70 (Figura 17A) são amarelados e translúcidos. Apresentam hábito idiomórfico a subdiomórfico, geralmente com formas prismáticas, alongadas ou curtas, e elipsoidais, raramente arredondadas ou subarredondadas. Imagens de catodoluminescência revelam zoneamento oscilatório ígneo, geralmente largo, na maioria dos cristais. Entretanto, alguns cristais apresentam metamictização local, sugerida por superfícies com manchas escuras que mascaram o zoneamento oscilatório original.

Foram analisados dezessete pontos em dezessete cristais, e três grupos com idades aparentes ${ }^{207} \mathrm{~Pb} /{ }^{206} \mathrm{~Pb}$ distintas foram individualizados. $\bigcirc$ grupo principal é formado por onze cristais (Tabela 4), que apresentaram razões Th/U entre 0,72 e 3,33, idades aparentes ${ }^{207} \mathrm{~Pb} /{ }^{06} \mathrm{~Pb}$ entre 1,99 e 1,95 Ga e forneceram idades de intercepto superior e inferior (Figura 17B) de $1978 \pm$ $6 \mathrm{Ma}(\mathrm{MSDW}=0,88)$ e $6 \pm 260 \mathrm{Ma}$, respectivamente. Adicionalmente, dois cristais concordantes deste grupo (discordância $=0 \%$ ), com razões isotópicas similares, forneceram idade concórdia de $1976 \pm 7$ Ma, que, dentro do erro analítico, é idêntica àquela obtida pelo intercepto superior, e ambas correspondem à idade de cristalização da rocha. A idade do intercepto inferior não apresenta significado geológico e deve representar perda recente de $\mathrm{Pb}$. O segundo grupo reúne três cristais com idades aparentes de $2513 \pm 5,2446 \pm 10$ e $2064 \pm 5$ Ma, que indicam herança arqueana e paleoproterozoica. $O$ terceiro grupo é formado por três cristais discordantes, com idades aparentes entre 1,86 e 1,93 Ga, que, no diagrama discórdia, mostram um padrão diferente em relação ao grupo principal, o que provavelmente foi ocasionado por desequilíbrio isotópico, já que estes cristais são muito fraturados, o que pode ter permitido a circulação de fluidos em escala microscópica.

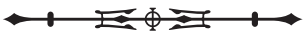




\begin{tabular}{|c|c|c|c|c|c|c|c|c|c|c|c|c|c|c|c|c|c|c|c|c|c|c|c|c|c|c|c|}
\hline & ¿ & $\begin{array}{l}c \\
\text { co } \\
\text { o }\end{array}$ & $\begin{array}{l}\stackrel{n}{m} \\
o^{\circ} \\
\stackrel{0}{0}\end{array}$ & $\begin{array}{l}m \\
0 \\
\text { o- } \\
\underline{0}\end{array}$ & $\begin{array}{l}0 \\
0 \\
0 \\
0\end{array}$ & 吕 & $\begin{array}{l}\sigma \\
0 \\
8 \\
8\end{array}$ & $\begin{array}{l}\infty \\
\infty \\
\mathbb{1} \\
\tilde{O}\end{array}$ & 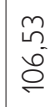 & ָָ & 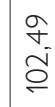 & 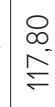 & 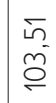 & 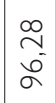 & $\begin{array}{l}q \\
q \\
\text { do } \\
\stackrel{0}{2}\end{array}$ & $\begin{array}{l}\stackrel{8}{2} \\
\stackrel{0}{=}\end{array}$ & $\bar{E}$ & $\begin{array}{l}\stackrel{2}{N} \\
\stackrel{2}{g} \\
\stackrel{2}{O}\end{array}$ & 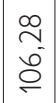 & 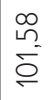 & $\begin{array}{l}\text { స్ } \\
\underline{\sigma}\end{array}$ & $\begin{array}{l}\stackrel{2}{0} \\
\text { 巳゙ } \\
\stackrel{0}{0}\end{array}$ & $\begin{array}{l}\stackrel{\sim}{\infty} \\
\stackrel{0}{0} \\
\stackrel{0}{0}\end{array}$ & 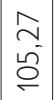 & $\begin{array}{l}\text { oे } \\
\text { oे } \\
\stackrel{0}{0}\end{array}$ & & 웅 \\
\hline & & $\approx$ & 우 & ㄱ & $\stackrel{2}{\sim}$ & $\stackrel{2}{\sim}$ & $\stackrel{\sim}{\sim}$ & $\tilde{m}$ & $\stackrel{\sigma}{=}$ & $\stackrel{\nexists}{\nu}$ & $\stackrel{\stackrel{\varphi}{m}}{m}$ & $\approx$ & $\ddot{\sim}$ & $\stackrel{ \pm}{\sim}$ & $\tilde{m}$ & ং & $\stackrel{+}{\sim}$ & 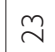 & $\stackrel{\sim}{\sim}$ & $\stackrel{\infty}{\sim}$ & ㄱ & 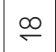 & $\stackrel{\sigma}{\sigma}$ & $\stackrel{\infty}{\simeq}$ & 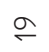 & $৯$ & \\
\hline & $\begin{array}{l}0 \\
0 \\
0 \\
0\end{array}$ & $\begin{array}{l}\text { o } \\
\text { gु }\end{array}$ & $\stackrel{N}{\stackrel{N}{N}}$ & $\stackrel{n}{\sim}$ & $\stackrel{\stackrel{\sim}{ \pm}}{\sim}$ & $\begin{array}{l}\stackrel{\infty}{\infty} \\
\stackrel{\infty}{\sim}\end{array}$ & $\stackrel{\text { 亗 }}{\stackrel{\sim}{n}}$ & 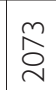 & $\stackrel{\bar{n}}{\sim}$ & 옹 & बे & $\begin{array}{l}\stackrel{\sim}{\infty} \\
\sim \\
\sim\end{array}$ & $\begin{array}{l}\bar{\infty} \\
\stackrel{\aleph}{\sim}\end{array}$ & $\underset{\sigma}{\sigma}$ & $\stackrel{\frac{\sigma}{\bar{N}}}{\stackrel{2}{n}}$ & $\stackrel{\bar{ָ}}{\underset{\sim}{\Delta}}$ & 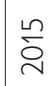 & 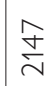 & 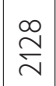 & $\stackrel{\infty}{\underset{\gamma}{N}}$ & 售 & $\begin{array}{l}\stackrel{a}{0} \\
\stackrel{人}{人}\end{array}$ & $\stackrel{\Xi}{\bar{N}}$ & $\stackrel{\stackrel{n}{亠}}{亡}$ & $\stackrel{\stackrel{\sim}{\sim}}{\stackrel{N}{ }}$ & 苂 & \\
\hline & 亡ㅝㅇ & $\simeq$ & $\approx$ & $\stackrel{m}{=}$ & $\stackrel{\nabla}{ }$ & $\stackrel{6}{ }$ & $\stackrel{m}{\leftarrow}$ & $\bar{N}$ & $\simeq$ & $\stackrel{m}{m}$ & $\approx$ & $\stackrel{\circ}{\circ}$ & $\stackrel{m}{=}$ & $\stackrel{\sim}{\underline{n}}$ & $\neq$ & $\stackrel{\llcorner}{\stackrel{n}{2}}$ & 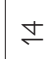 & $\stackrel{m}{\underline{m}}$ & $\stackrel{\llcorner}{\llcorner}$ & $\stackrel{6}{2}$ & 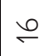 & $\digamma$ & $F$ & $\stackrel{\simeq}{\simeq}$ & $\ddot{\nabla}$ & $\stackrel{\circ}{\circ}$ & \\
\hline & 颃 & ڤి & $\begin{array}{l}\hat{\infty} \\
\stackrel{\nu}{0}\end{array}$ & 훙 & 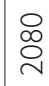 & $\stackrel{\circ}{\stackrel{\sim}{N}}$ & $\stackrel{\infty}{\grave{\nu}}$ & 悉 & 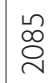 & 点 & ஜ & 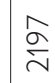 & 웅 & $\begin{array}{l}\infty \\
\stackrel{\infty}{\sigma}\end{array}$ & 离 & $\stackrel{\sigma}{\bar{\lambda}}$ & 芦 & 令 & 㕝 & ָָ & $\stackrel{m}{\tilde{i}}$ & 文 & ๙ָे & ชู & 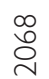 & & \\
\hline & 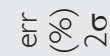 & 으 & $\ddot{\sim}$ & $\stackrel{ }{ }$ & 으 & ㄱ & 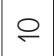 & ৯ & $\stackrel{n}{\square}$ & $\simeq$ & $\lesssim$ & $\stackrel{\Perp}{\sim}$ & $\stackrel{2}{ }$ & $\neq$ & 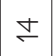 & $=$ & $\stackrel{m}{\underline{m}}$ & $\stackrel{\sim}{\stackrel{n}{2}}$ & $\neq$ & 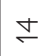 & $\stackrel{ \pm}{\sim}$ & 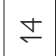 & $\stackrel{m}{\underline{m}}$ & 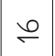 & থ & $\stackrel{\infty}{\simeq}$ & \\
\hline & & ç & 峉 & స్ & 호 & $\stackrel{+}{\stackrel{+}{\sim}}$ & $\overline{\bar{\sigma}}$ & 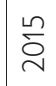 & 호․ & 홍 & 옹 & $\stackrel{\sim}{\stackrel{\sim}{\sim}}$ & $\overline{\bar{\nu}}$ & 호 & 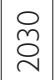 & స్ & $\stackrel{m}{\grave{\nu}}$ & 웅 & 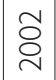 & 호․ & ণ્రి & 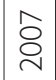 & 苂 & 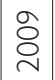 & ઠิ) & & \\
\hline & & ठ & $\mid \begin{array}{l}0 \\
\infty \\
0 \\
0\end{array}$ & $\begin{array}{l}1 \\
\infty \\
0^{-}\end{array}$ & $\begin{array}{l}\tilde{\sigma} \\
\tilde{\sigma}\end{array}$ & $\begin{array}{l}\frac{n}{\stackrel{n}{0}} \\
\tilde{o}^{-}\end{array}$ & $\begin{array}{l}\bar{\sigma} \\
\bar{\sigma}\end{array}$ & $\begin{array}{l}8 \\
0 \\
0\end{array}$ & $\begin{array}{l}\hat{E} \\
0^{-}\end{array}$ & $\begin{array}{l}a \\
\infty \\
0 \\
0^{-}\end{array}$ & $\begin{array}{l}\infty \\
0 \\
0\end{array}$ & $\begin{array}{l}\circ \\
\infty \\
0\end{array}$ & $\begin{array}{l}\infty \\
\infty \\
0 \\
0\end{array}$ & $\begin{array}{c}m \\
\infty \\
0^{-}\end{array}$ & $\begin{array}{l}\bar{\sigma} \\
\bar{\sigma}\end{array}$ & $\begin{array}{l}\alpha \\
\sigma \\
0\end{array}$ & $\begin{array}{l}\alpha \\
\sigma \\
o\end{array}$ & $\begin{array}{l}\mathscr{M} \\
\infty \\
0 \\
0\end{array}$ & $\begin{array}{l}0 \\
0 \\
0 \\
0\end{array}$ & $\begin{array}{l}\text { or } \\
0 \\
0\end{array}$ & $\begin{array}{l}\infty \\
\infty \\
0\end{array}$ & $\begin{array}{l}\infty \\
\hat{0} \\
0\end{array}$ & $\mid \begin{array}{l}0 \\
\infty \\
0 \\
0\end{array}$ & $\begin{array}{l}m \\
\tilde{o} \\
0^{-}\end{array}$ & $\begin{array}{l}\bar{\infty} \\
\sigma_{0}^{-}\end{array}$ & $\begin{array}{l}m \\
\infty \\
0 \\
0\end{array}$ & \\
\hline$\sum^{\pi}$ & & $\stackrel{\cong}{=}$ & $\frac{0}{i}$ & $\Xi$ & $\underset{f}{\stackrel{f}{=}}$ & $\stackrel{\circ}{=}$ & $\stackrel{m}{m}$ & $\stackrel{\infty}{\infty}$ & $\stackrel{\stackrel{\leftrightarrow}{O}}{-}$ & $\stackrel{\sim}{\sim}$ & $\stackrel{\circ}{=}$ & $\stackrel{m}{=}$ & 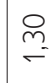 & $\underset{\leftarrow}{\stackrel{f}{-}}$ & $\stackrel{\stackrel{n}{2}}{=}$ & 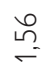 & $\stackrel{a}{m}$ & $\stackrel{\infty}{=}$ & $\stackrel{\hat{m}}{=}$ & 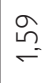 & $\stackrel{0}{=}$ & $\stackrel{8}{-}$ & $\stackrel{0}{\circ}$ & $\stackrel{\sigma}{\stackrel{-}{\sigma}}$ & $\stackrel{m}{\circ}$ & & \\
\hline 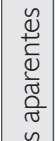 & & $\mid \begin{array}{l}\sigma \\
\bar{D} \\
\tilde{n} \\
\tilde{n} \\
0\end{array}$ & $\begin{array}{l}8 \\
8 \\
8 \\
+ \\
0\end{array}$ & $\begin{array}{l}0 \\
0 \\
\infty \\
o \\
m \\
0 \\
0\end{array}$ & $\begin{array}{l}\hat{\sigma} \\
\text { o } \\
\text { a } \\
m \\
0\end{array}$ & $\begin{array}{l}\mathcal{N} \\
\alpha \\
\alpha \\
\tilde{m} \\
0\end{array}$ & $\mid \begin{array}{l}\infty \\
\infty \\
\infty \\
o 0 \\
0 \\
m \\
0 \\
0\end{array}$ & $\begin{array}{l}\bar{\sigma} \\
\alpha \\
\tilde{\sigma} \\
m \\
o\end{array}$ & $\begin{array}{l}\infty \\
\frac{n}{\tilde{\sigma}} \\
\alpha \\
\tilde{m} \\
0\end{array}$ & $\begin{array}{l}\infty \\
\infty \\
0 \\
\infty \\
\infty \\
m \\
0 \\
0\end{array}$ & $\begin{array}{c}\underset{n}{\stackrel{m}{m}} \\
\infty \\
m \\
0\end{array}$ & \begin{tabular}{c}
$\mathcal{J}$ \\
$\underset{f}{f}$ \\
\multirow{f}{*}{} \\
0
\end{tabular} & $\begin{array}{l}\hat{\alpha} \\
\text { o } \\
\text { o } \\
\text { m } \\
o\end{array}$ & 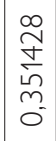 & 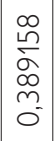 & $\frac{\sigma}{\frac{\sigma}{\sigma}}$ & $\begin{array}{l}\text { t } \\
\text { o } \\
0 \\
0 \\
\text { m. } \\
0\end{array}$ & 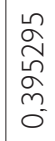 & $\mid \begin{array}{c}\sigma \\
\bar{o} \\
o \\
j \\
o \\
o\end{array}$ & $\begin{array}{l}\bar{\alpha} \\
\tilde{\alpha} \\
\tilde{m} \\
o\end{array}$ & $\begin{array}{c}\frac{0}{\sigma} \\
m \\
m \\
m \\
0\end{array}$ & 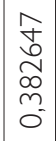 & $\begin{array}{l}\stackrel{2}{\alpha} \\
\underset{T}{+} \\
\infty \\
m \\
0 \\
0\end{array}$ & $\mid \begin{array}{c}\infty \\
o \\
o \\
\infty \\
\infty \\
m \\
0 \\
0\end{array}$ & $\begin{array}{l}\stackrel{0}{\mathcal{T}} \\
\stackrel{\sigma}{\sigma} \\
\stackrel{\text { }}{0} \\
\sigma^{-}\end{array}$ & & i \\
\hline 吾 & ะัฮ @ & $\stackrel{?}{9}$ & in & $\stackrel{0}{\longleftarrow}$ & $\stackrel{\stackrel{n}{\stackrel{n}{-}}}{-}$ & $\stackrel{\infty}{\stackrel{\infty}{=}}$ & $\underset{+}{\stackrel{f}{r}}$ & $\stackrel{+}{\mathrm{m}}$ & $\stackrel{\leftrightarrow}{m}$ & 守 & $\stackrel{\circ}{\sim}$ & $\stackrel{2}{\stackrel{2}{z}}$ & $\underset{f}{\stackrel{f}{二}}$ & $\stackrel{+}{\stackrel{t}{=}}$ & $\stackrel{\alpha}{=}$ & $\stackrel{a}{b}$ & $\stackrel{n}{\stackrel{n}{2}}$ & $\stackrel{2}{\stackrel{2}{2}}$ & $\underline{0}$ & $\stackrel{\infty}{\stackrel{\infty}{=}}$ & $\stackrel{\infty}{\stackrel{\infty}{=}}$ & $\stackrel{\stackrel{n}{\simeq}}{=}$ & $\stackrel{\overbrace{}}{\stackrel{丶}{=}}$ & 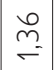 & $\stackrel{+}{\stackrel{2}{n}}$ & $\stackrel{+}{\infty}$ & \\
\hline & & o & $\begin{array}{c}\frac{m}{\infty} \\
\infty \\
\sigma\end{array}$ & \begin{tabular}{l}
$f$ \\
\multirow{f}{*}{} \\
0 \\
0
\end{tabular} & 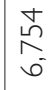 & $\begin{array}{l}\infty \\
0 \\
0 \\
\end{array}$ & $\begin{array}{l}n \\
\stackrel{n}{N} \\
\sigma\end{array}$ & \begin{tabular}{|l}
$n$ \\
$\infty$ \\
$\infty$ \\
+ \\
$\sigma$
\end{tabular} & $\begin{array}{l}\frac{\sigma}{\Omega} \\
\hat{\sigma} \\
0\end{array}$ & 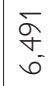 & $\begin{array}{l}\text { f } \\
\text { b. } \\
0\end{array}$ & $\begin{array}{l}\sigma \\
\sigma \\
\sigma \\
N\end{array}$ & $\begin{array}{l}\text { 尺ै } \\
\text { กิ } \\
0\end{array}$ & $\begin{array}{l}n \\
\delta \\
\sigma \\
0\end{array}$ & $\begin{array}{c}\frac{0}{1} \\
b^{-}\end{array}$ & $\begin{array}{l}\widetilde{\sigma} \\
\stackrel{\circ}{N}\end{array}$ & 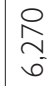 & $\begin{array}{l}\hat{\omega} \\
\infty \\
0 \\
0\end{array}$ & $\mid \begin{array}{c}0 \\
0 \\
0 \\
0 \\
0\end{array}$ & $\begin{array}{l}\infty \\
\stackrel{\infty}{m} \\
\tilde{m}^{-}\end{array}$ & $\begin{array}{l}m \\
\text { ot } \\
0\end{array}$ & $\begin{array}{l}\stackrel{0}{n} \\
0 \\
0\end{array}$ & 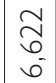 & $\left|\begin{array}{l}\infty \\
\vdots \\
0 \\
0\end{array}\right|$ & 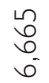 & 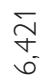 & \\
\hline & 잉 & $\begin{array}{l}\infty \\
\stackrel{0}{0} \\
0\end{array}$ & $\stackrel{\infty}{\stackrel{\infty}{=}}$ & $\begin{array}{l}\stackrel{2}{\Omega} \\
0\end{array}$ & 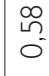 & $\stackrel{\stackrel{n}{\rightleftarrows}}{=}$ & $\begin{array}{l}n \\
\tilde{0} \\
0\end{array}$ & 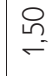 & $\begin{array}{l}+ \\
\infty \\
0 \\
0\end{array}$ & రి & $\stackrel{n}{\stackrel{n}{ }}$ & $\stackrel{\stackrel{\rho}{m}}{\rightleftharpoons}$ & $\begin{array}{l}\sigma \\
0 \\
0\end{array}$ & $\begin{array}{l}0 \\
2 \\
0\end{array}$ & $\begin{array}{l}\sigma \\
\hat{0}\end{array}$ & $\begin{array}{l}n \\
\tilde{0} \\
0\end{array}$ & $\frac{\pi}{\stackrel{N}{0}}$ & $\begin{array}{l}\tilde{N} \\
0 \\
0 \\
0\end{array}$ & $\begin{array}{l}\stackrel{2}{\alpha} \\
\hat{o}\end{array}$ & $\begin{array}{l}\infty \\
\infty \\
0\end{array}$ & $\stackrel{+}{m}$ & $\begin{array}{l}0 \\
\tilde{0}\end{array}$ & $\begin{array}{l}\mathbb{N} \\
0^{-}\end{array}$ & $\begin{array}{l}\bar{\sigma} \\
\bar{\sigma}\end{array}$ & $\stackrel{n}{=}$ & $\stackrel{8}{\stackrel{-}{-}}$ & \\
\hline & & $\begin{array}{l}\bar{\sigma} \\
\stackrel{D}{2} \\
\stackrel{2}{0}\end{array}$ & 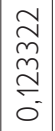 & $\mid \begin{array}{c}\mathcal{n} \\
\underset{f}{J} \\
\stackrel{-}{0}\end{array}$ & 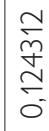 & $\begin{array}{l}\stackrel{0}{\sim} \\
\stackrel{0}{\sim} \\
\stackrel{0}{0}\end{array}$ & $\begin{array}{c}0 \\
N \\
\tilde{N} \\
\stackrel{0}{0} \\
0\end{array}$ & $\begin{array}{l}\bar{\tau} \\
\stackrel{\sigma}{d} \\
\stackrel{0}{0}\end{array}$ & 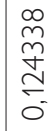 & 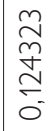 & 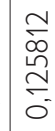 & 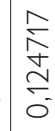 & 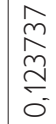 & 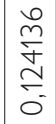 & $\mid \begin{array}{l}\stackrel{2}{2} \\
\stackrel{\leftrightarrow}{2} \\
\stackrel{2}{0}\end{array}$ & $\begin{array}{l}\stackrel{m}{\infty} \\
\stackrel{\infty}{\sim} \\
\stackrel{0}{0}\end{array}$ & 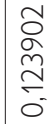 & $\begin{array}{l}\infty \\
0 \\
\stackrel{2}{2} \\
\stackrel{2}{\leftarrow} \\
0\end{array}$ & 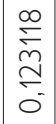 & 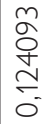 & 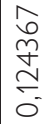 & $\begin{array}{l}8 \\
\stackrel{0}{n} \\
\stackrel{2}{0} \\
0\end{array}$ & 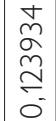 & $\mid \begin{array}{c}\frac{v}{0} \\
\stackrel{2}{2} \\
\stackrel{0}{0}\end{array}$ & $\begin{array}{l}\underset{\alpha}{\alpha} \\
\stackrel{2}{2} \\
0 \\
0\end{array}$ & 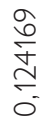 & 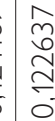 \\
\hline & 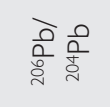 & 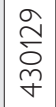 & 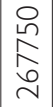 & $\begin{array}{l}8 \\
8 \\
\infty \\
0 \\
0\end{array}$ & 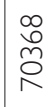 & 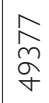 & 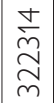 & 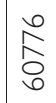 & 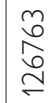 & ふ̊. & $\underline{8}$ & $\begin{array}{l}\stackrel{m}{\infty} \\
\stackrel{\infty}{\rho}\end{array}$ & 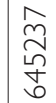 & $\begin{array}{l}\stackrel{n}{\infty} \\
\stackrel{\sim}{\Psi} \\
\forall\end{array}$ & $\begin{array}{l}\bar{F} \\
\infty \\
\infty \\
\infty\end{array}$ & $\begin{array}{l}\text { ○े } \\
\text { ț } \\
\text { 유 }\end{array}$ & $\begin{array}{l}\bar{ָ} \\
\text { ऽ } \\
\stackrel{\leftrightarrow}{+}\end{array}$ & 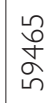 & $\begin{array}{l}\tilde{\tilde{R}} \\
\hat{\Omega}\end{array}$ & $\begin{array}{l}\infty \\
\stackrel{\infty}{m} \\
\stackrel{\sigma}{\sigma}\end{array}$ & $\begin{array}{l}2 \\
\alpha \\
\alpha \\
\infty\end{array}$ & $\frac{a}{\sigma}$ & 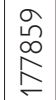 & 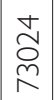 & 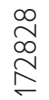 & & \\
\hline & & $\begin{array}{l}\text { : } \\
0-\end{array}$ & $\begin{array}{l}\mathfrak{z} \\
\mathfrak{o} \\
0\end{array}$ & $\begin{array}{l}m \\
\tilde{\sigma} \\
\sigma^{\prime}\end{array}$ & さે & $\begin{array}{l}\infty \\
+ \\
0 \\
0\end{array}$ & $\begin{array}{l}\tilde{2} \\
0 \\
0\end{array}$ & $\begin{array}{l}0 \\
0 \\
0 \\
0\end{array}$ & $\begin{array}{l}\tilde{T} \\
\tilde{\sigma}\end{array}$ & $\begin{array}{l}\tilde{\sigma} \\
\sigma^{\prime}\end{array}$ & $\begin{array}{l}\stackrel{\sim}{2} \\
\stackrel{2}{0} \\
0\end{array}$ & $\bar{\sigma}$ & $\begin{array}{l}\bar{\sigma} \\
0\end{array}$ & $\begin{array}{l}\Re \\
\stackrel{n}{0} \\
0\end{array}$ & $\begin{array}{l}\hat{f} \\
\dot{0} \\
0^{\prime}\end{array}$ & 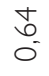 & $\begin{array}{l}\hat{f} \\
0 \\
0\end{array}$ & $\begin{array}{l}0 \\
\vdots \\
0\end{array}$ & $\begin{array}{l}n \\
\hat{N} \\
0^{-}\end{array}$ & $\begin{array}{l}2 n \\
0 \\
0 \\
0\end{array}$ & $\begin{array}{l}\widetilde{J} \\
0 \\
0\end{array}$ & $\begin{array}{l}\infty \\
m \\
\tilde{c}\end{array}$ & $\begin{array}{l}n \\
0 \\
0 \\
0\end{array}$ & $\begin{array}{l}\bar{\kappa} \\
\tilde{o}\end{array}$ & 苞 & 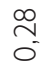 & \\
\hline & 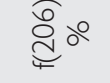 & 8 & $\bar{\delta}$ & $\begin{array}{l}8 \\
0\end{array}$ & Õ & mo & 8 & $\begin{array}{l}\sigma \\
O \\
O\end{array}$ & $\bar{\sigma}$ & $\stackrel{E}{0}$ & $\begin{array}{l}\Omega \\
\tilde{\sigma}\end{array}$ & $\delta_{0}^{\delta}$ & 8 & $\begin{array}{l}\stackrel{\sim}{m} \\
m \\
0\end{array}$ & $\begin{array}{l}\sigma \\
0 \\
0\end{array}$ & $\begin{array}{l}8 \\
0\end{array}$ & 8 & $\begin{array}{l}\sigma \\
\sigma \\
0\end{array}$ & $\begin{array}{l}\sigma \\
\sigma \\
0\end{array}$ & $\begin{array}{l}\sigma \\
0 \\
0\end{array}$ & $\sigma_{0}$ & $\overline{0}$ & $\bar{\delta}_{0}$ & $\begin{array}{l}\sigma \\
O \\
0\end{array}$ & $\bar{\delta}$ & $\begin{array}{l}\text { Õ } \\
\text { o. }\end{array}$ & \\
\hline & 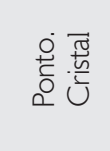 & 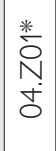 & 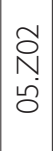 & $\begin{array}{l}\infty \\
\tilde{o} \\
N \\
g \\
0\end{array}$ & $\begin{array}{l}z \\
m \\
\hat{N} \\
N \\
\hat{o}\end{array}$ & 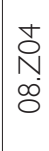 & 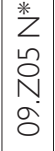 & $\begin{array}{l}0 \\
2 \\
N \\
N \\
0\end{array}$ & $\begin{array}{l}\stackrel{2}{~} \\
\stackrel{n}{=}\end{array}$ & $\begin{array}{l}\hat{O} \\
\text { N } \\
\text { ․ }\end{array}$ & $\begin{array}{l}Z \\
\infty \\
0 \\
N \\
\stackrel{n}{n}\end{array}$ & $\begin{array}{l}\infty \\
\infty \\
0 \\
0 \\
0\end{array}$ & $\begin{array}{l}\hat{\partial} \\
N \\
\end{array}$ & $\begin{array}{l}\stackrel{O}{N} \\
\stackrel{\infty}{\simeq}\end{array}$ & $\begin{array}{l}\stackrel{m}{N} \\
\sim \\
\sim\end{array}$ & $\begin{array}{l}\stackrel{\forall}{N} \\
\stackrel{ \pm}{\sim}\end{array}$ & \begin{tabular}{l}
$* *$ \\
\multirow{N}{N}{} \\
$\mathscr{N}$ \\
$N$
\end{tabular} & $\frac{\bar{N}}{N}$ & $\begin{array}{l}\infty \\
\bar{N} \\
\infty \\
\sim\end{array}$ & 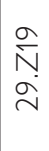 & $\begin{array}{l}\stackrel{ }{N} \\
\text { O }\end{array}$ & $\begin{array}{l}\bar{N} \\
\text { m} \\
m\end{array}$ & $\begin{array}{l}\widetilde{N} \\
\stackrel{+}{m} \\
m\end{array}$ & $\mid \begin{array}{l}\tilde{N} \\
\sim \\
m \\
m\end{array}$ & 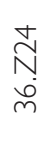 & $\underset{\substack{\stackrel{n}{N} \\
\stackrel{\sim}{N}}}{ }$ & \\
\hline
\end{tabular}

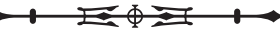




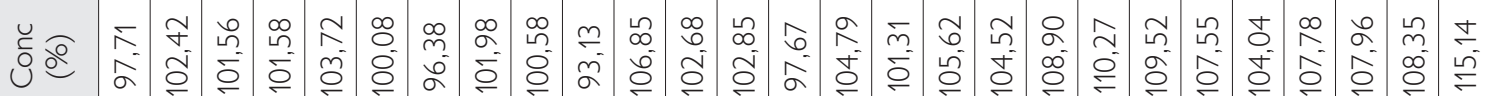
u

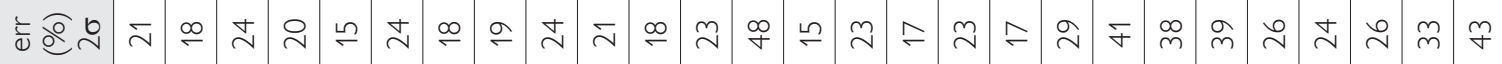

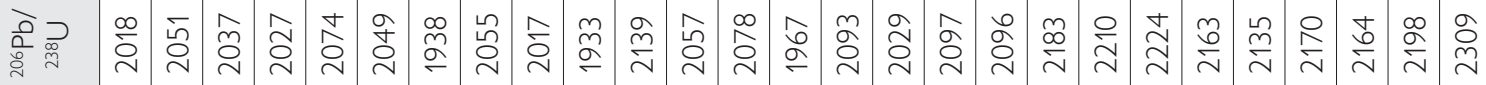

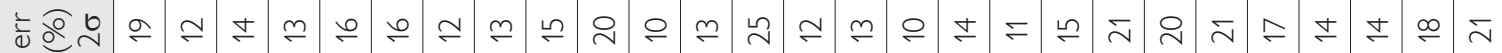

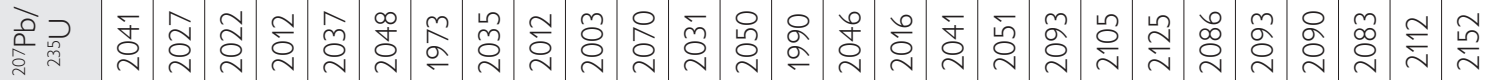

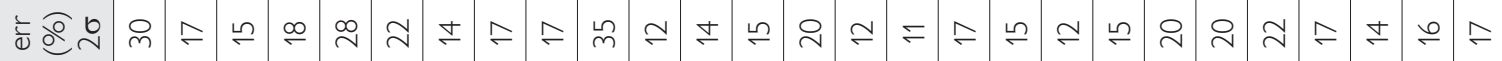

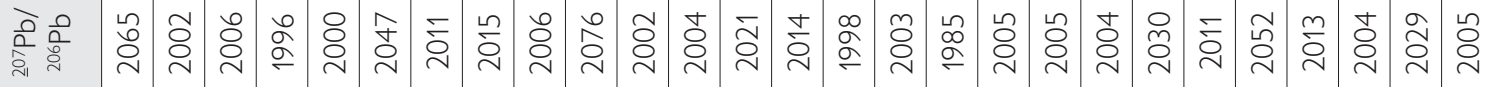

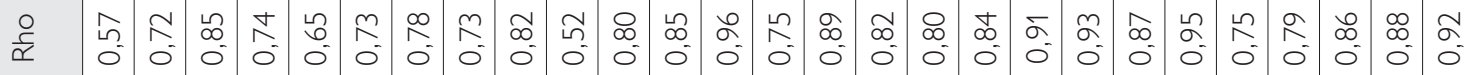

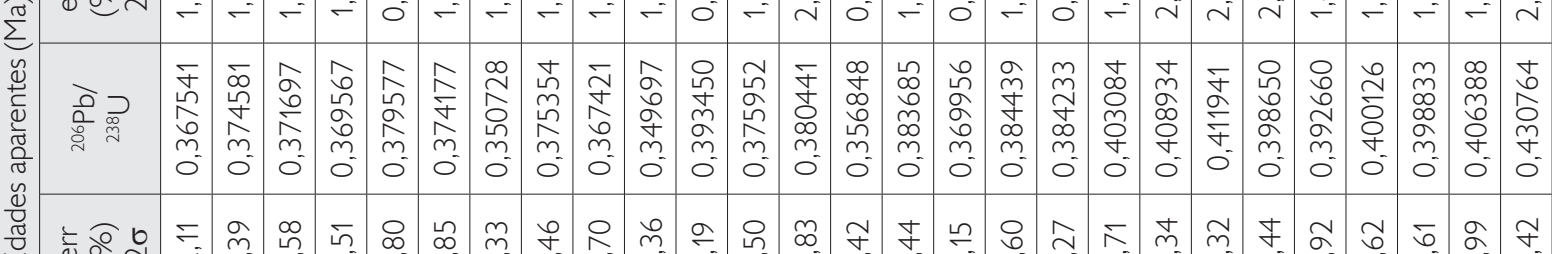

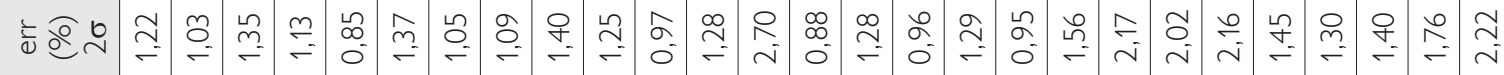

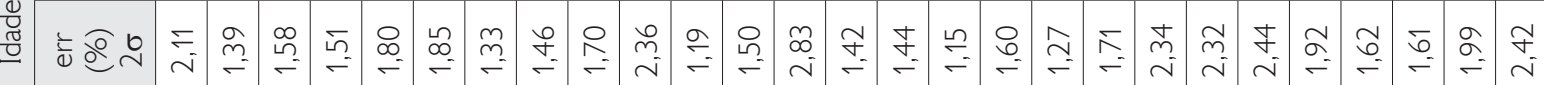

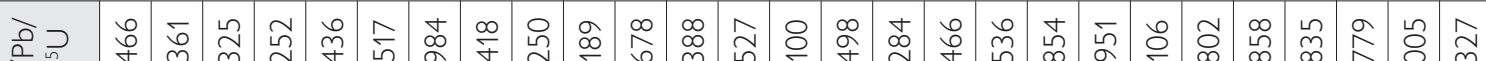

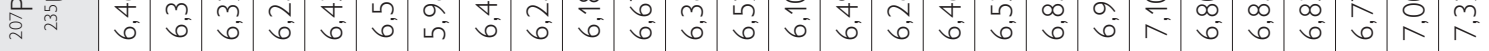

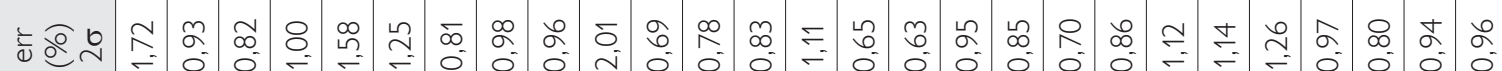

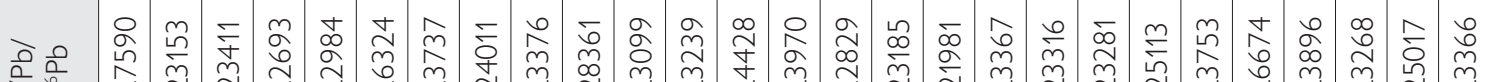
ơ :

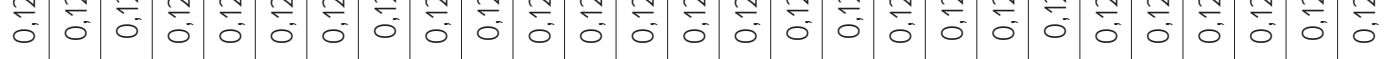

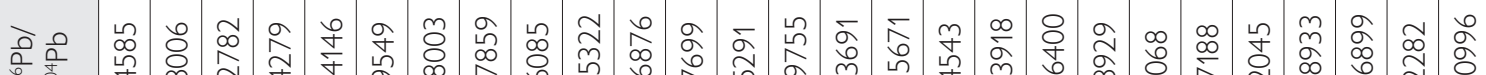
0
0
$o$

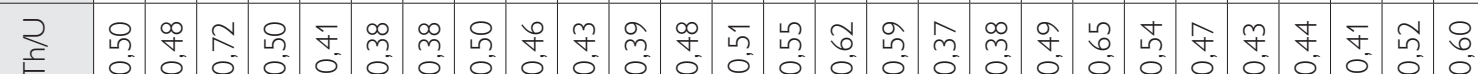

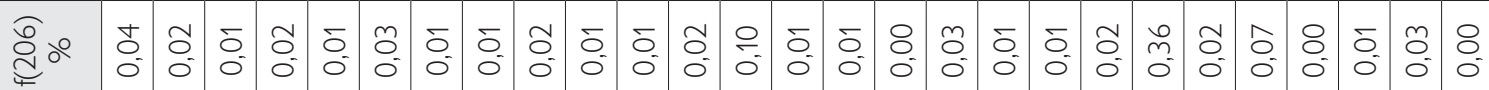

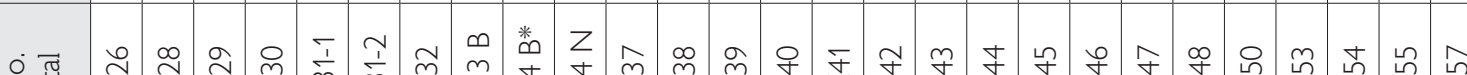




\begin{tabular}{|c|c|c|c|c|c|}
\hline & $\stackrel{u}{u} \stackrel{\varrho}{\varrho}$ & $\begin{array}{l}\sigma \\
\hat{\sigma} \\
\sigma \\
\sigma\end{array}$ & $\begin{array}{l}\text { 음 } \\
\stackrel{0}{\circ}\end{array}$ & $\begin{array}{l}\stackrel{\Xi}{\Xi} \\
\stackrel{E}{E}\end{array}$ & $\begin{array}{l}\text { กิ } \\
\text { ข้ }\end{array}$ \\
\hline & ๑ัญ $\stackrel{0}{\varrho}$ & $\ddot{\sim}$ & $\stackrel{\curvearrowright}{\sim}$ & $\stackrel{\mathscr{\nu}}{\sim}$ & F \\
\hline & 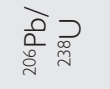 & $\begin{array}{l}\circ \\
\stackrel{े}{0} \\
\end{array}$ & $\begin{array}{l}\infty \\
\stackrel{\infty}{\sim}\end{array}$ & 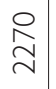 & శ్ \\
\hline & ๕ัญ & $\stackrel{\simeq}{\simeq}$ & $\stackrel{n}{\llcorner}$ & $\stackrel{\infty}{-}$ & $\stackrel{\searrow}{\sim}$ \\
\hline & 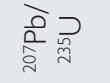 & ָे & $\begin{array}{l}0 \\
\text { ठे } \\
\text { ते }\end{array}$ & $\stackrel{\stackrel{\varphi}{+}}{\sim}$ & $\stackrel{+}{\stackrel{*}{\circ}}$ \\
\hline & 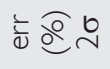 & $=$ & $\stackrel{m}{\sim}$ & 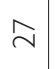 & 으 \\
\hline & 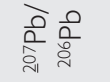 & 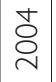 & ठั & స્તે & $\stackrel{\infty}{\stackrel{\sim}{~}}$ \\
\hline & $\frac{o}{\alpha}$ & $\begin{array}{l}2 \\
0 \\
0\end{array}$ & $\mid$ & $\begin{array}{l}\stackrel{\llcorner}{\infty} \\
\infty \\
0 \\
0\end{array}$ & $\begin{array}{l}0 \\
0 \\
0\end{array}$ \\
\hline$\sum^{\pi}$ & 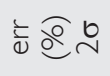 & 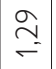 & 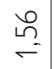 & $\stackrel{\infty}{m}$ & 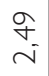 \\
\hline 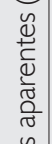 & 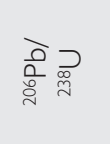 & 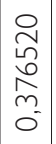 & 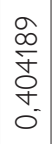 & 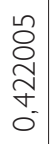 & 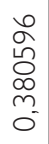 \\
\hline 茜 & ¿ัव & $\stackrel{m}{=}$ & $\stackrel{N}{\stackrel{2}{=}}$ & $\stackrel{\vec{i}}{\mathrm{i}}$ & $\underset{\sim}{\stackrel{n}{\sim}}$ \\
\hline & 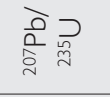 & $\begin{array}{l}8 \\
\vdots \\
0 \\
0\end{array}$ & $\begin{array}{c}\hat{N} \\
\infty \\
0 \\
0\end{array}$ & $\begin{array}{l}\infty \\
\stackrel{0}{0} \\
\stackrel{N}{N}\end{array}$ & 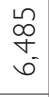 \\
\hline & 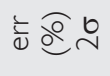 & $\mid \begin{array}{l}\mathrm{J} \\
0 \\
0\end{array}$ & $\left|\begin{array}{c}N \\
0^{-}\end{array}\right|$ & $\stackrel{\stackrel{m}{\rightleftarrows}}{=}$ & $\stackrel{?}{=}$ \\
\hline & 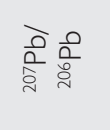 & 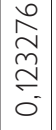 & $\begin{array}{l}\bar{\sigma} \\
\stackrel{0}{2} \\
\stackrel{0}{\sigma} \\
\bar{\sigma}\end{array}$ & $\begin{array}{l}\text { Oे } \\
\stackrel{d}{d} \\
\stackrel{2}{0} \\
0\end{array}$ & 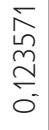 \\
\hline & $\begin{array}{l}\text { aे } \\
\text { âे } \\
\text { 웜 }\end{array}$ & 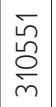 & 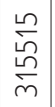 & $\begin{array}{l}\infty \\
\stackrel{2}{ } \\
\widetilde{1} \\
\infty\end{array}$ & $\stackrel{\stackrel{P}{m}}{\stackrel{m}{m}}$ \\
\hline & $\underset{F}{\stackrel{一}{F}}$ & $\begin{array}{l}\tilde{n} \\
0 \\
0\end{array}$ & $\begin{array}{l}\stackrel{0}{2} \\
0 \\
0\end{array}$ & กี & $\begin{array}{l}\tilde{f} \\
\tilde{\sigma}\end{array}$ \\
\hline & 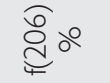 & $\begin{array}{l}8 \\
0 \\
0\end{array}$ & 8 & $\begin{array}{l}\tilde{O} \\
\tilde{O} \\
0\end{array}$ & 8 \\
\hline & 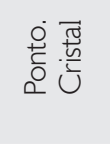 & $\begin{array}{l}\infty \\
0 \\
N \\
+ \\
\infty \\
\infty\end{array}$ & $\begin{array}{l}\sigma \\
\hat{n} \\
\omega \\
\infty \\
\infty\end{array}$ & $\begin{array}{l}D \\
\stackrel{2}{ } \\
D \\
\infty\end{array}$ & $\begin{array}{l}z \\
n \\
N \\
N \\
2 \\
2\end{array}$ \\
\hline
\end{tabular}

\begin{tabular}{|c|c|c|c|c|c|c|c|c|c|c|c|c|}
\hline 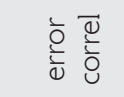 & \multirow{17}{*}{ 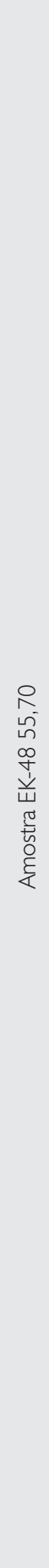 } & $\begin{array}{l}\alpha \\
\sigma^{2} \\
0\end{array}$ & $\begin{array}{l}0 \\
\vdots \\
0 \\
0\end{array}$ & $\begin{array}{l}0 \\
0 \\
0 \\
0\end{array}$ & $\begin{array}{l}0 \\
\hat{\sigma} \\
0 \\
0\end{array}$ & $\begin{array}{l}\bar{\alpha} \\
\sigma \\
0\end{array}$ & $\begin{array}{l}\infty \\
0 \\
\alpha \\
0 \\
0\end{array}$ & $\begin{array}{l}\infty \\
\stackrel{\infty}{\alpha} \\
\sigma \\
0\end{array}$ & $\begin{array}{l}\hat{n} \\
\sigma \\
0\end{array}$ & $\begin{array}{l}t \\
\sigma \\
\sigma \\
\sigma\end{array}$ & \begin{tabular}{l}
$m$ \\
\multirow{\sigma}{\sigma}{} \\
0
\end{tabular} & $\begin{array}{l}\frac{1}{2} \\
2 \\
0\end{array}$ \\
\hline$\underline{b}$ & & $\stackrel{\sim}{i}$ & $\stackrel{\sim}{\sim}$ & $\stackrel{\sim}{\sim}$ & $\stackrel{\sqrt{3}}{ }$ & $\bar{i}$ & $\bar{i}$ & $\approx$ & $\stackrel{\sim}{\sim}$ & $\bar{i}$ & $\stackrel{\sim}{\sim}$ & $\approx$ \\
\hline 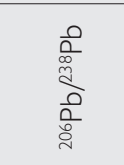 & & 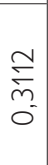 & $\mid \begin{array}{l}\infty \\
\infty \\
m \\
m \\
0 \\
0\end{array}$ & 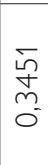 & $\begin{array}{l}\stackrel{0}{f} \\
\text { m } \\
0 \\
0\end{array}$ & $\begin{array}{c}a \\
\hat{f} \\
m \\
0 \\
o\end{array}$ & 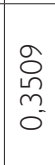 & 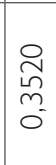 & $\begin{array}{l}\stackrel{\circ}{i n} \\
\stackrel{m}{0} \\
0\end{array}$ & $\begin{array}{l}\stackrel{0}{2} \\
\stackrel{n}{m} \\
0\end{array}$ & 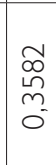 & $\begin{array}{l}0 \\
o \\
m \\
0 \\
0\end{array}$ \\
\hline$\underline{0}$ & & $\stackrel{\sim}{\sim}$ & $\begin{array}{l}\sigma^{\prime} \\
\sigma^{2}\end{array}$ & $\begin{array}{l}\text { i } \\
0\end{array}$ & $\stackrel{m}{i}$ & $\stackrel{\sim}{\sim}$ & $\widetilde{\sim}$ & $\widetilde{v}$ & $\stackrel{m}{\sim}$ & $\widetilde{v}$ & $\stackrel{m}{i}$ & $\approx$ \\
\hline 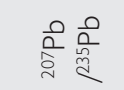 & & $\underset{\text { స̃ }}{\text { ஸ் }}$ & $\begin{array}{l}0 \\
0 \\
0 \\
1\end{array}$ & $\stackrel{P}{\stackrel{P}{n^{-}}}$ & $\underset{\hat{n}}{\hat{n}}$ & $\begin{array}{l}m \\
\infty \\
\omega^{\prime}\end{array}$ & $\begin{array}{l}\infty \\
\infty \\
\omega^{-}\end{array}$ & $\begin{array}{l}0 \\
\infty \\
\infty \\
\omega^{-}\end{array}$ & $\begin{array}{l}8 \\
\alpha \\
n\end{array}$ & $\begin{array}{l}\infty \\
\alpha \\
\text { ம் }\end{array}$ & $\begin{array}{l}\infty \\
\alpha \\
\kappa\end{array}$ & $\underset{0}{E}$ \\
\hline$\underline{0}$ & & $\begin{array}{l}t_{0} \\
0^{2}\end{array}$ & $\stackrel{\stackrel{n}{0}}{\circ}$ & $\begin{array}{l}0 \\
0^{\circ}\end{array}$ & $t_{0}^{t}$ & m & $\tilde{0}$ & $\begin{array}{l}t \\
0^{-}\end{array}$ & $\stackrel{\mathscr{n}}{0}$ & $\tilde{c}$ & $\stackrel{n}{0}$ & $\stackrel{+}{0}$ \\
\hline $\begin{array}{l}0 \\
0 \\
0 \\
0 \\
0 \\
0 \\
0 \\
0\end{array}$ & & $\begin{array}{l}\underset{\infty}{\simeq} \\
\underset{0}{-}\end{array}$ & 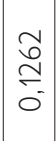 & 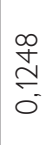 & 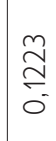 & 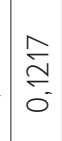 & 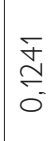 & $\underset{\Xi}{\stackrel{\Xi}{Z}}$ & $\underset{\stackrel{+}{\sim}}{\stackrel{\sim}{\sim}}$ & $\frac{0}{\stackrel{I}{0}}$ & 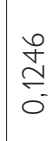 & $\stackrel{\stackrel{n}{\sim}}{\stackrel{\sim}{\sigma}}$ \\
\hline ○ & & $\stackrel{m}{\sigma}$ & in & $\sim$ & $\sim$ & $m$ & $\sim$ & $\sim$ & $\sim$ & 0 & 0 & - \\
\hline$\underline{b}$ & & $a$ & $\stackrel{\infty}{\infty}$ & $\stackrel{\sim}{\sim}$ & 으 & in & $\infty$ & $\infty$ & $\simeq$ & t & 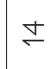 & $a$ \\
\hline 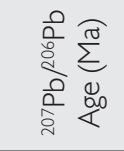 & & $\begin{array}{l}\sigma \\
\infty \\
\sigma\end{array}$ & $\frac{\tilde{N}}{\stackrel{\alpha}{\sigma}}$ & $\stackrel{+}{\stackrel{+}{\sigma}}$ & $\begin{array}{l}\widehat{\sigma} \\
\stackrel{\sigma}{\sigma}\end{array}$ & $\begin{array}{l}\stackrel{\sigma}{\alpha} \\
\stackrel{\sigma}{\sigma}\end{array}$ & $\begin{array}{l}\stackrel{n}{\alpha} \\
\stackrel{\sigma}{\sigma}\end{array}$ & $\begin{array}{l}0 \\
2 \\
2\end{array}$ & $\begin{array}{l}m \\
\propto \\
\sigma \\
\sigma\end{array}$ & $\stackrel{\hat{\alpha}}{\sigma}$ & $\underset{\alpha}{\stackrel{\alpha}{\sigma}}$ & 合 \\
\hline$\underline{0}$ & & $\stackrel{\sim}{m}$ & $\begin{array}{l}\vec{v} \\
\dot{m} \\
m\end{array}$ & $\begin{array}{l}\dot{t}_{0} \\
\dot{m} \\
m\end{array}$ & $\stackrel{\sim}{\stackrel{N}{m}}$ & $\begin{array}{l}0 \\
\stackrel{n}{m} \\
m\end{array}$ & $\begin{array}{l}\sigma \\
\omega_{m}^{-}\end{array}$ & $\begin{array}{l}m \\
\tilde{s}^{-}\end{array}$ & $\begin{array}{l}0 \\
0 \\
\text { m. }\end{array}$ & $\begin{array}{l}m \\
\tilde{m} \\
m\end{array}$ & $\begin{array}{l}\sigma \\
\bar{\omega} \\
\tilde{m}\end{array}$ & $\underset{m}{\stackrel{N}{m}}$ \\
\hline 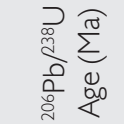 & & $\begin{array}{l}\infty \\
\sigma^{-} \\
\stackrel{1}{\Sigma} \\
\end{array}$ & $\begin{array}{l}\alpha \\
0 \\
o \\
\infty \\
\infty \\
\infty\end{array}$ & Е & $\begin{array}{l}0 \\
\text { Zे } \\
\stackrel{2}{\sigma}\end{array}$ & $\begin{array}{l}\stackrel{\nwarrow}{ \pm} \\
\stackrel{\Delta}{\sigma}\end{array}$ & $\begin{array}{l}\hat{N} \\
\infty \\
\tilde{m} \\
\stackrel{\sigma}{\sigma}\end{array}$ & 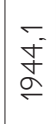 & $\begin{array}{l}m \\
\alpha \\
\tilde{\sigma}\end{array}$ & $\begin{array}{l}\sigma \\
\tilde{\sigma} \\
\sigma \\
\sigma\end{array}$ & $\begin{array}{l}0 \\
\stackrel{N}{\alpha} \\
\stackrel{\sigma}{\sigma}\end{array}$ & $\begin{array}{l}0 \\
\stackrel{0}{ } \\
\infty \\
\sigma \\
\sigma\end{array}$ \\
\hline 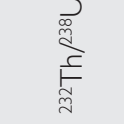 & & $\begin{array}{l}\mathbb{N} \\
\hat{0}\end{array}$ & $\begin{array}{l}\bar{\sigma} \\
\bar{\sigma}\end{array}$ & i. & $\bar{ָ}$ & $\stackrel{m}{m}$ & $\begin{array}{c}\bar{z} \\
\bar{z}\end{array}$ & $\stackrel{\sim}{\tilde{N}}$ & 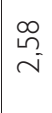 & $\stackrel{g}{g}$ & $\stackrel{8}{=}$ & $\stackrel{\infty}{\stackrel{9}{\sim}}$ \\
\hline$\frac{\varepsilon}{\alpha} \risingdotseq$ & & $\stackrel{\stackrel{\llcorner}{\varrho}}{\leftarrow}$ & $\stackrel{\stackrel{\sim}{m}}{\stackrel{m}{n}}$ & 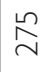 & $\begin{array}{c}m \\
\stackrel{\infty}{m}\end{array}$ & $\underset{g}{g}$ & $\underset{⿱}{\stackrel{\infty}{f}}$ & $\underset{⿱ 亠 䒑}{n}$ & 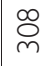 & 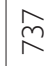 & $\bar{ָ}$ & $\stackrel{\curvearrowright}{\curvearrowright}$ \\
\hline ह & & & $\stackrel{+}{\stackrel{+}{L}}$ & $\stackrel{\infty}{\stackrel{\infty}{m}}$ & $\stackrel{尺}{\stackrel{2}{2}}$ & ర్ & $\underset{\mho}{ }$ & సે & $\stackrel{\cong}{\beth}$ & $\widetilde{R}$ & సે & $\underline{E}$ \\
\hline ১ & & $\stackrel{2}{\stackrel{2}{0}}$ & $\begin{array}{l}\infty \\
\stackrel{\infty}{0} \\
0 \\
0\end{array}$ & 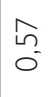 & $\frac{\sigma}{0}$ & $\begin{array}{l}\tilde{O} \\
0 \\
0\end{array}$ & $\tilde{n}$ & $\stackrel{2}{0}$ & $\stackrel{E}{0}$ & $\begin{array}{l}\tilde{O} \\
0 \\
0\end{array}$ & $\begin{array}{l}q \\
0 \\
0\end{array}$ & $\begin{array}{l}\infty \\
0 \\
0\end{array}$ \\
\hline 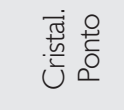 & & $\stackrel{\text { * }}{\stackrel{i}{\longrightarrow}}$ & $\bar{\sigma}$ & $\bar{\sigma}$ & $\bar{\infty}^{\circ}$ & $\bar{m}$ & ஜே & $\check{F}$ & $\bar{\pi}$ & $\bar{i}$ & $\stackrel{\text { *ै }}{\stackrel{m}{m}}$ & 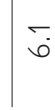 \\
\hline
\end{tabular}




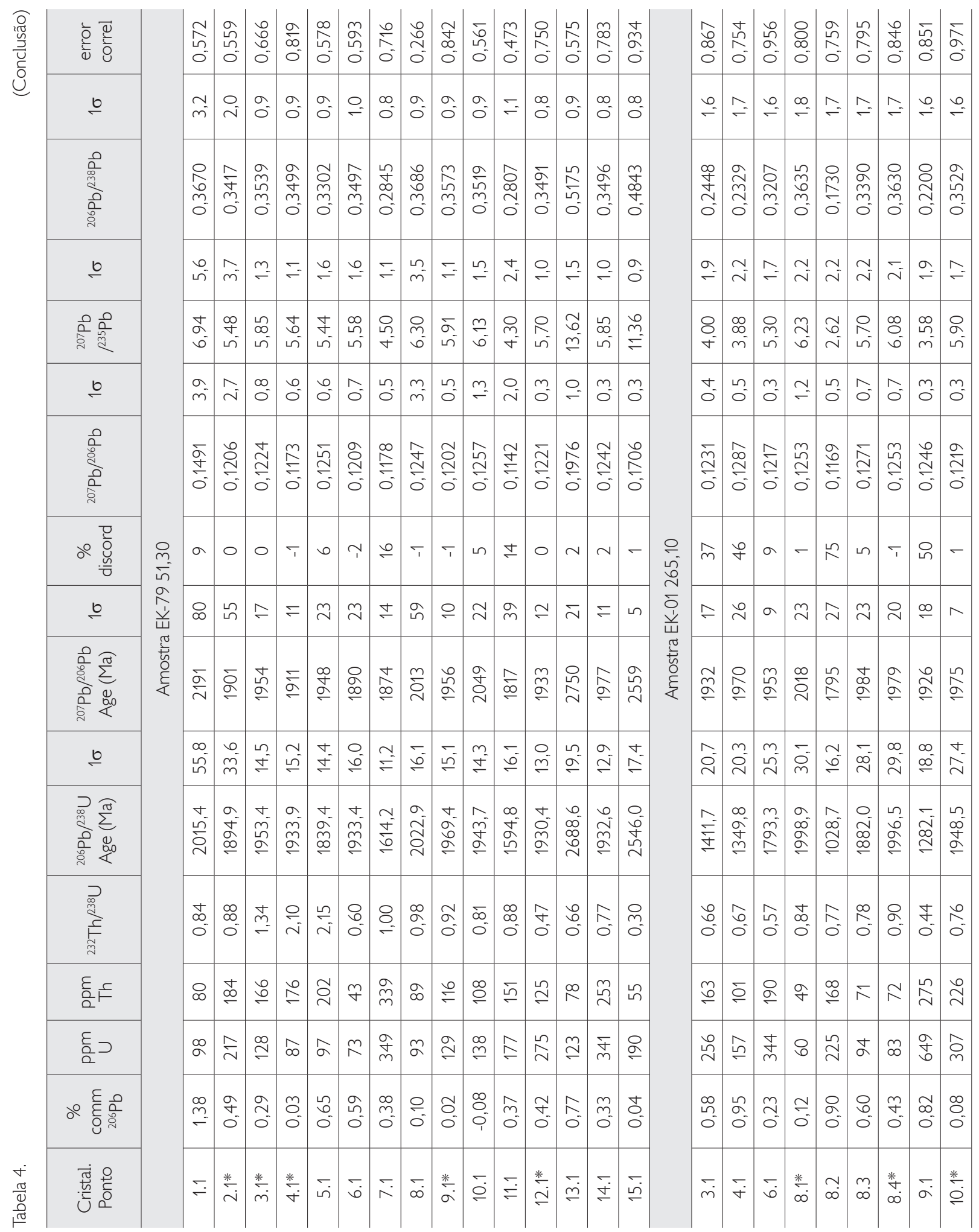




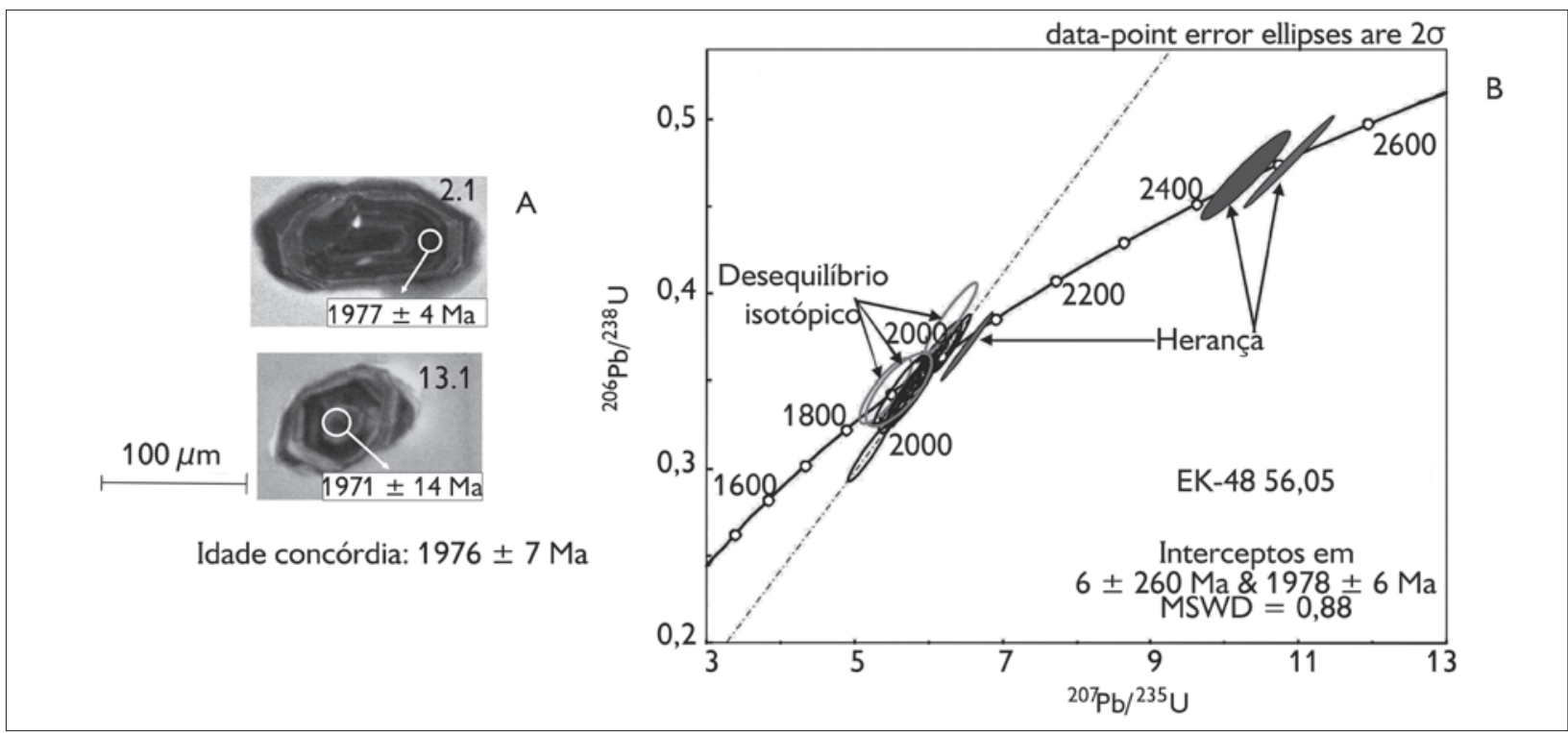

Figura 17. A) Imagens de catodoluminescência de cristais de zircão representativos de biotita granodiorito, com a indicação do local dos pontos analisados (círculos), as idades aparentes ${ }^{207} \mathrm{~Pb} / 206 \mathrm{~Pb}$ e a idade concórdia fornecida pelos dois cristais em destaque; B) diagrama discórdia mostrando idade de intercepto superior, calculada com base em onze pontos analisados em onze cristais (explicações no texto).

\section{Biotita monzogranito}

Os cristais de zircão da amostra EK-79 51,30 (Figura 18A) são idiomórficos a subdiomórficos e, em geral, formam prismas curtos a médios, com terminações mono ou bipiramidais. Alguns cristais apresentam terminações arredondadas e formatos ligeiramente elipsoidais, o que pode representar reabsorção magmática. Cristais de formato completamente arredondado são raros. Boa parte dos cristais apresenta zoneamento oscilatório ígneo, geralmente em bandas largas, truncado localmente por fraturas. Cristais aparentemente sem zoneamento, com zoneamento convoluto ou setorial, ou ainda com núcleos luminescentes são raros. Evidências de metamictização ocorrem localmente e são representadas por setores com baixa luminescência, que mascaram o zoneamento oscilatório original, e por zonas de crescimento de alta ou baixa luminescência, que marcam a descontinuidade entre núcleo e borda em alguns cristais.

Foram analisados quinze pontos em quinze cristais e a maioria deles forneceu idades aparentes ${ }^{207} \mathrm{~Pb} / 206 \mathrm{~Pb}$ variáveis, entre 1,90 e 1,97 Ga (Tabela 4). Os cristais muito discordantes ou com alto conteúdo de $U$ foram desconsiderados.

Utilizando apenas cinco cristais concordantes (discordância = 0\%), foi obtida uma idade concórdia de $1930 \pm 5 \mathrm{Ma}$ (MSWD = 1,6; Figura 18B). Com o refinamento do cálculo, considerando entre os cinco cristais aqueles com razões isotópicas mais próximas, foram obtidas mais três idades concórdias (Figura 18A): $1958 \pm 7$ Ma (MSWD =0,52), $1931 \pm 9 \mathrm{Ma}(M S W D=0,054)$ e $1918 \pm 9 \mathrm{Ma}(M S W D=$ 3,1). A interpretação mais simples é a de que a idade inferior corresponda à idade de cristalização da rocha e as idades maiores representem herança.

\section{Muscovita monzogranito}

Os cristais de zircão da amostra EK-01 265,10 (Figura 19A) são geralmente idiomórficos a subdiomórficos, constituem prismas longos e curtos, com terminações mono ou bipiramidais e geralmente apresentam zoneamento oscilatório ígneo largo, truncado por fraturas em alguns cristais. A maioria dos cristais apresenta bordas e/ou núcleos metamícticos e zoneamento original parcial ou inteiramente obliterado.

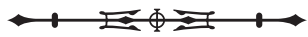




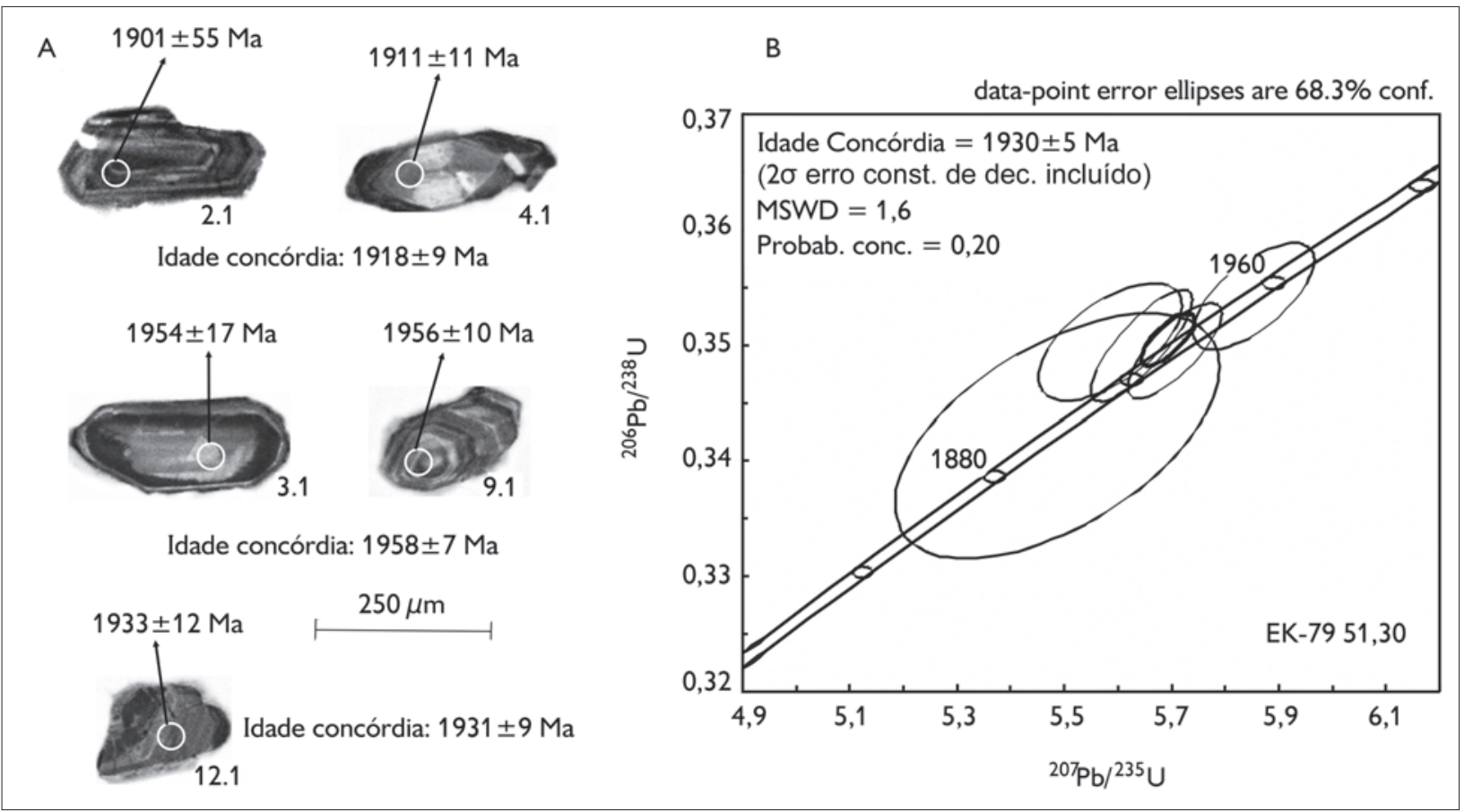

Figura 18. A) Imagens de catodoluminescência de cristais de zircão representativos de biotita monzogranito, com a indicação do local dos pontos analisados (círculos), as idades aparentes ${ }^{207} \mathrm{~Pb} /{ }^{206} \mathrm{~Pb}$ de cada cristal e as idades concórdias fornecidas por cada par de cristais ou cristal em destaque; B) diagrama concórdia mostrando idade obtida para cinco pontos analisados em cinco cristais (explicações no texto).

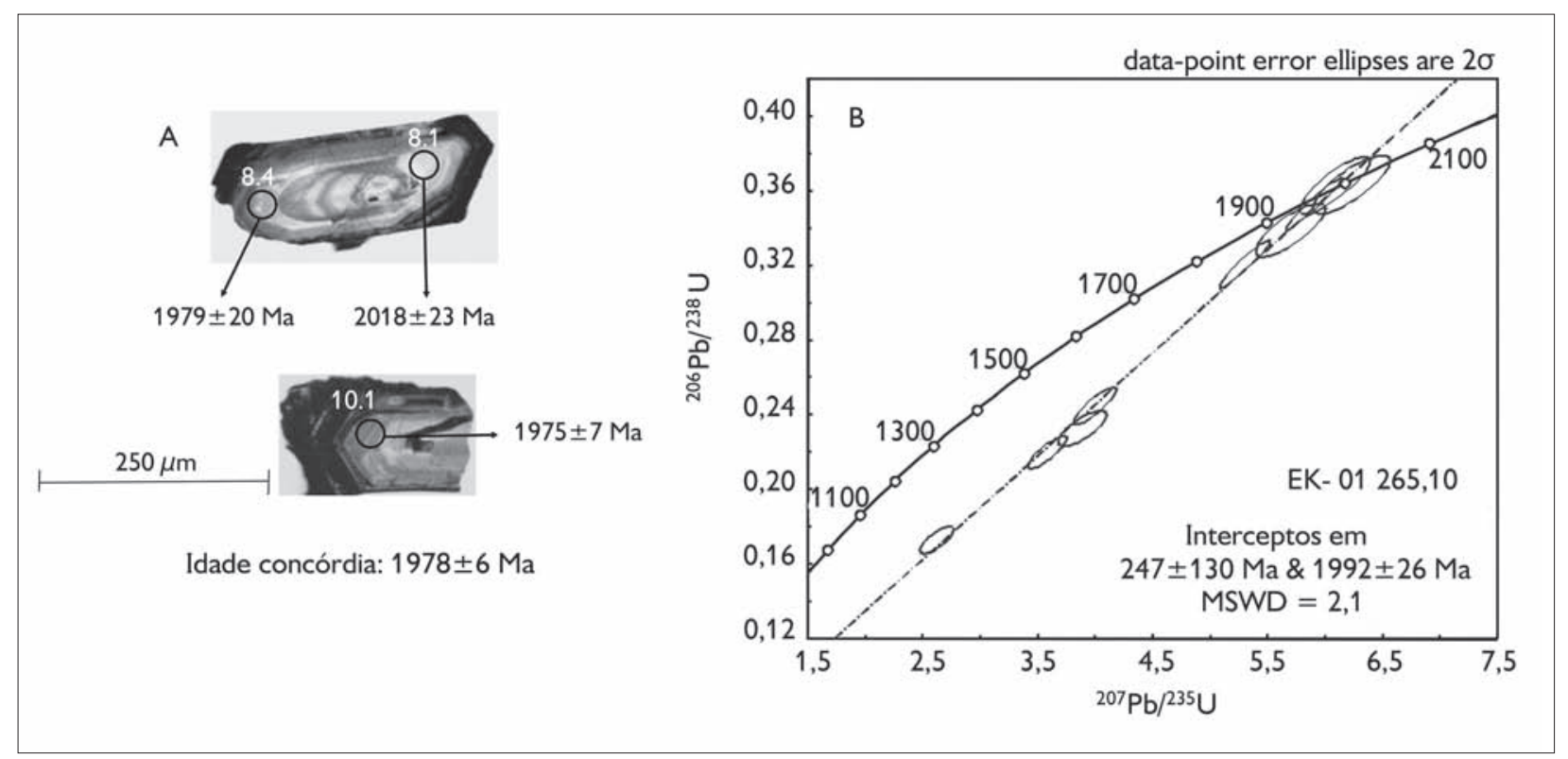

Figura 19. A) Imagens de catodoluminescência de cristais de zircão representativos de muscovita monzogranito, com a indicação do local dos pontos analisados (círculos), as idades aparentes ${ }^{207} \mathrm{~Pb} /{ }^{06} \mathrm{~Pb}$ em cada ponto e a idade concórdia obtida com base nos três pontos mais concordantes dos dois cristais destacados; B) diagrama discórdia mostrando idade de intercepto superior, calculada com base em nove pontos analisados em seis cristais (explicações no texto).

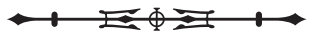


Foram analisados nove pontos em seis cristais, que forneceram idades aparentes ${ }^{207} \mathrm{~Pb} /{ }^{206} \mathrm{~Pb}$ principalmente entre 1,92 e 1,98 Ga (Tabela 4). Quatro pontos analisados no cristal 8 (Tabela 4) apresentaram idades diferentes, duas delas fora do intervalo principal: $2018 \pm 23$ Ma e $1795 \pm$ $27 \mathrm{Ma}$; essas idades foram obtidas na borda do cristal e apresentam discordância de 1,0 e 75\%, respectivamente. Considerando todas as análises, foram obtidas idades de intercepto superior e inferior de $1992 \pm 26 \mathrm{Ma}$ (MSWD = 2,1) e $247 \pm 130 \mathrm{Ma}$, respectivamente (Figura 19B). Com o refinamento do cálculo, considerando apenas os dados mais concordantes deste grupo ( $\pm 1 \%$ de discordância), foi obtida idade concórdia de $1978 \pm 6$ Ma (MSWD $=0$ e probabilidade de concordância de 0,98) (Figura 19A). Esta é provavelmente a melhor estimativa para a idade de cristalização da rocha. Apesar do elevado erro analítico, a idade de $247 \pm 130$ Ma fornecida pelo intercepto inferior sugere perda de $\mathrm{Pb}$, que pode estar relacionada a intrusões de diabásios mesozoicos conhecidos no Domínio Tapajós.

\section{DISCUSSÕES}

De modo geral, os cinco litotipos descritos (Tabela 1) diferem quanto às fases varietais associadas. Apenas o dacito porfirítico contém anfibólio; os granitoides contêm biotita ou muscovita, ou nenhum mineral varietal. A mineralogia acessória é praticamente a mesma em todos os litotipos, mas há algumas variações texturais e granulométricas. Além disso, as rochas diferem quanto à intensidade da alteração hidrotermal e da deformação que as afetou. Algumas foram afetadas com menor intensidade e suas texturas ígneas originais encontram-se bem preservadas, já em outras, intensamente hidrotermalizadas e/ou deformadas, essas texturas foram parcial ou mesmo completamente obliteradas.

Dos litotipos descritos, o dacito porfirítico, o biotita granodiorito e o sienogranito apresentaram clara relação de contato intrusivo com as rochas metassedimentares da Formação Castelo dos Sonhos (Figuras 3E, 5A, 5D e 8A). Entretanto, devido às limitações inerentes ao estudo por meio de testemunhos de sondagem, a mesma relação de contato não foi observada para o biotita monzogranito e para o muscovita monzogranito. Ainda assim, é possível que estes também sejam intrusivos na sequência metassedimentar da bacia.

Além das diferenças petrográficas, essas rochas diferem quanto aos padrões geoquímicos e, com exceção do sienogranito, que não foi datado, distinguem-se pelas idades de cristalização, compondo três grupos temporalmente distintos (Tabela 1).

Quanto à discriminação tectônica, todos os litotipos plotaram nos campos dos granitos de arco vulcânico e pós-colisonais (Figuras 10B a 10D), sendo necessárias investigações adicionais para definir se esse resultado reflete o ambiente de formação dessas rochas ou a fonte dos magmas.

O dacito porfirítico apresenta similaridades gerais nos padrões de ETR e elementos-traço tanto com os granitoides calcioalcalinos da Suíte Intrusiva Creporizão quanto com os do Complexo Cuiú-Cuiú (Figuras 11A a 11D), no entanto, algumas diferenças devem ser ressaltadas. No Complexo Cuiú-Cuiú, são inexistentes anomalias negativas de Eu e a disposição fortemente inclinada dos ETRP indica intenso fracionamento desses elementos, o que contrasta com o padrão de fracionamento moderado de ETRP e as discretas anomalias negativas de Eu do dacito porfirítico (Figura 11C), que, por outro lado, mostra um padrão de elementostraço muito semelhante ao do Cuiú-Cuiú, exceto pela anomalia negativa de $\mathrm{P}$ menos acentuada (Figura11D).

Em relação à Suíte Intrusiva Creporizão, o dacito porfirítico mostra anomalias negativas de Eu equivalentes e um padrão de fracionamento de ETRP muito similar, mas dela difere por apresentar apenas discretas anomalias negativa de $\mathrm{Ba}$ e positiva de $\mathrm{Pb}$ (Figuras 11A e 11B).

O padrão de ETR do dacito porfirítico indica que, assim como as rochas da Suíte Intrusiva Creporizão (Vasquez et al., 2002), sua assinatura calcioalcalina é mais evoluída do que a do Complexo Cuiú-Cuiú.

Por outro lado, sua idade de cristalização de $2011 \pm 6$ Ma é compatível com o Complexo Cuiú-Cuiú, entretanto, 
as diferenças geoquímicas anteriormente apontadas diminuem a possibilidade de que o dacito porfirítico esteja relacionado a essa unidade. É possível que faça parte do conjunto de rochas vulcânicas com idades de $2020 \pm 2$ a $2012 \pm 2$ Ma que ocorrem na porção leste do Domínio Tapajós e foram reunidas na Formação Comandante Arara (Vasquez et al., 2013), para a qual ainda não há dados geoquímicos disponíveis que permitam comparação.

Ainda em relação ao Complexo Cuiú-Cuiú, vale considerar que, em suas principais áreas de ocorrência e em sua definição original, essa unidade reunia rochas metamórficas (Pessoa et al., 1977). Muitos granitoides foram incluídos no complexo por apresentarem idades coincidentes com o amplo intervalo de 2033-2005 Ma a ele atribuído ou pela impossibilidade de individualizá-los apropriadamente nas escalas de mapeamento adotadas, o que significa que nem todas as rochas reunidas no Complexo Cuiú-Cuiú compartilham da mesma origem.

$O$ biotita granodiorito também apresenta afinidade calcioalcalina e seu padrão de ETR, com anomalias negativas de Eu quase inexistentes e importante fracionamento de ETRP (Figura 12C), é muito semelhante ao do Complexo Cuiú-Cuiú, assim como os padrões nos diagramas multielementares também se assemelham, exceto pela ausência de anomalias positivas de $\mathrm{Pb}$ no biotita granodiorito (Figura 12D). Este, por outro lado, diferencia-se da Suíte Intrusiva Creporizão por mostrar um fracionamento perceptivelmente mais acentuado de ETRP e pela ausência de anomalias negativas significativas de Eu (Figura 12A), mostrando-se também mais enriquecido em $\mathrm{Ba}$ e bem mais empobrecido em Pb (Figura 12B). Apesar dos padrões geoquímicos não completamente coincidentes, a idade de cristalização de $1976 \pm 7$ Ma obtida para o biotita granodiorito indica sua relação temporal com o magmatismo da Suíte Intrusiva Creporizão.

Também de afinidade calcioalcalina, o biotita monzogranito assemelha-se ao Complexo Cuiú-Cuiú por seu padrão de ETR sem anomalias negativas de Eu significativas e com expressivo fracionamento de ETRP
(Figura 13A), seguindo também, de modo geral, o mesmo padrão do Cuiú-Cuiú nos diagramas multielementares, exceto por mostrar anomalia negativa de $\mathrm{P}$ bem menos acentuada (Figura 13B). Por outro lado, diferencia-se da Suíte Intrusiva Creporizão por mostrar anomalia negativa de Eu mais fraca e maior fracionamento de ETRP (Figura 13C), mostrando-se também consideravelmente mais enriquecido em $\mathrm{Ba}$ e menos enriquecido em Pb (Figura 13D). O biotita monzogranito também difere da Suíte Intrusiva Tropas no padrão de ETR por mostrar apenas leve anomalia negativa de Eu e não apresentar anomalia negativa de Sm (Figura 13E).

Três idades concordantes distintas foram obtidas para o biotita monzogranito: uma mais antiga, de $1958 \pm 7 \mathrm{Ma}$; uma mais jovem, de $1918 \pm 9$ Ma; e uma intermediária, de $1931 \pm 9$ Ma. Embora não encontre correspondentes temporais nos domínios Tapajós ou Iriri-Xingu, a idade de 1931 土 9 Ma não é completamente desprezada, pois pode representar um magmatismo calcioalcalino desconhecido na região, cuja existência, no entanto, necessita de mais estudos para ser comprovada. Nesse caso, a idade mais antiga representaria herança e a idade mais jovem poderia representar um episódio de perda de $\mathrm{Pb}$ relacionado a evento incerto.

Outra possibilidade é a de que a idade mais antiga, $1958 \pm 7$ Ma, represente a cristalização da rocha e as duas idades mais jovens representem perda de $\mathrm{Pb}$ em eventos mais recentes. Nesse caso, o biotita monzogranito poderia ser correlacionado temporalmente à Suíte Intrusiva Creporizão, no entanto, suas diferenças geoquímicas em relação a essa unidade desfavorecem essa hipótese. Também contraria essa hipótese a necessidade de explicar a coincidência de dois eventos que provocassem desequilíbrio do sistema U-Th- $\mathrm{Pb}$, mas que mantivessem a concordância das razões isotópicas.

Por último, a interpretação mais provável e simples é a de que a idade mais jovem, $1918 \pm 9 \mathrm{Ma}$, corresponda à cristalização da rocha e as duas idades mais antigas representem herança. Essa idade, dentro do 
erro analítico, é compatível com o intervalo atribuído à Suíte Tropas, o que correlaciona temporalmente o biotita monzogranito a essa unidade, embora haja diferenças no padrão geoquímico.

Em relação ao muscovita monzogranito, este apresenta padrão ETR "asa de gaivota", marcado por profunda anomalia negativa de Eu, além de fracionamento de ETRL e enriquecimento em ETRP, características que o assemelham à Suíte Intrusiva Maloquinha (Figura 14A). Entretanto, ao contrário desta, o muscovita monzogranito mostra considerável empobrecimento em Pb (Figura 14B), além disso, não são conhecidos granitos com muscovita na Suíte Intrusiva Maloquinha (Vasquez et al., 2002, 2008b). Por outro lado, o muscovita monzogranito é muito diferente dos granitoides da Suíte Intrusiva Creporizão e do Complexo Cuiú-Cuiú quanto ao padrão de ETR (Figuras 14C e 14E), distinguindo-se do Complexo Cuiú-Cuiú também nos diagramas multielementares (Figura 14F), embora mostre padrão um tanto mais ajustado em relação à Suíte Intrusiva Creporizão, com ressalvas quanto ao significativo empobrecimento em Pb, Sr, P, Zr e Ti (Figura 14D).

A idade de cristalização de $1978 \pm 6$ Ma obtida para o muscovita monzogranito relaciona-o temporalmente à Suíte Intrusiva Creporizão, embora haja diferenças geoquímicas e a ocorrência de granitos com muscovita ainda não tenha sido descrita nessa unidade (Vasquez et al., 2002, 2008b).

Assim como o muscovita monzogranito, o sienogranito mostra padrão ETR de tendência alcalina e também assemelha-se à Suíte Intrusiva Maloquinha, embora com enriquecimento menos acentuado em ETRP e anomalia negativa de Eu menos profunda (Figuras 15A e 15B). $O$ comportamento geral dos LILE e HFSE no sienogranito também é muito semelhante ao da Suíte Intrusiva Maloquinha, embora o sienogranito se mostre mais enriquecido em Ba e mais empobrecido em Nb, Pb e P (Figura 15B). A ausência de dados geocronológicos não permite que correlações temporais sejam sugeridas para o sienogranito em relação a unidades dos domínios Tapajós ou Iriri-Xingu.
A idade de cristalização compatível tanto com o Complexo Cuiú-Cuiú quanto com a Formação Comandante Arara obtida para o dacito porfirítico $(2011 \pm 6 \mathrm{Ma})$ e a idade compatível com a Suíte Intrusiva Creporizão obtida para o biotita granodiorito (1976 \pm 7 Ma), assim como as relações de contato intrusivas observadas entre essas rochas e a sequência metassedimentar da Formação Castelo dos Sonhos podem ser consideradas fortes indicativos da relação estratigráfica desta unidade com o Domínio Tapajós, apontando uma vez mais para a necessidade de revisão do limite que atualmente o separa do Domínio Iriri-Xingu. Além disso, a idade de $2011 \pm 6$ Ma pode ser considerada como a idade mínima de sedimentação da Formação Castelo dos Sonhos e, consequentemente, da mineralização aurífera singenética nela hospedada.

Na porção leste do Domínio Tapajós, onde se acreditava que predominasse vulcano-plutonismo de 1893-1872 Ma, trabalhos recentes têm mostrado uma ocorrência mais extensa de rochas vulcânicas com idades em torno de 2000 Ma e entre 2020-2012 Ma, além de granitoides de 2016-2010 Ma. Os dados isotópicos (SmNd) obtidos para as rochas vulcânicas de 2020-2012 Ma $\left(T_{D M}=2,29\right.$ e 2,36 Ga; $\varepsilon N d=-0,59$ e -1,19) e para os granitoides de 2016-2010 Ma ( $T_{D M}=2,41$ a 2,62 Ga e $\varepsilon N d=-1,49$ a $-5,45)$ mostraram que houve pouca participação de crosta arqueana na formação dessas rochas. As idades-modelo mais antigas e os valores de $\varepsilon N d$ fracamente negativos podem refletir diferentes graus de mistura de crosta arqueana com magmas juvenis acrescidos há cerca de 2,1 Ga no Domínio Tapajós (Vasquez et al., 2014b).

Ao norte da Formação Castelo dos Sonhos, foram também obtidas idades em torno de 1,97 Ga para rochas vulcânicas anteriormente correlacionadas ao Evento Uatumã sensu lato, além de idades mais antigas, de 2123 \pm 86 a $2023 \pm 30 \mathrm{Ma}$, para tonalitos do embasamento na região (Tokashiki et al., 2014; Guimarães et al., 2015).

Esses dados refletem a dinâmica atual do conhecimento geológico no Cráton Amazônico, demonstrando sensível 
diminuição nas áreas antes relacionadas ao magmatismo Uatumã e mostrando a ocorrência, cada vez mais a leste, de rochas que apresentam idades e/ou assinaturas isotópicas compatíveis com as do Domínio Tapajós, o que reforça a tendência de continuidade deste domínio a leste, para além do limite que atualmente o separa do Domínio Iriri-Xingu.

\section{CONCLUSÕES}

Os dados obtidos neste trabalho permitiram a classificação de cinco diferentes litotipos: dacito porfirítico, biotita granodiorito, sienogranito, biotita monzogranito e muscovita monzogranito, dos quais os três primeiros são claramente intrusivos nas rochas da Formação Castelo dos Sonhos ( < 2083-2080 Ma), enquanto a natureza intrusiva dos demais não pôde ser comprovada.

O dacito porfirítico revelou idade de cristalização $(U$ $\mathrm{Pb}$ LA-ICP-MS) de $2011 \pm 6 \mathrm{Ma}$, idade compatível com o Complexo Cuiú-Cuiú, embora as diferenças nos padrões geoquímicos tornem pouco provável que a rocha pertença a esta unidade, estando mais provavelmente relacionada à Formação Comandante Arara.

O biotita granodiorito apresentou idade de cristalização (U-Pb SHRIMP) de $1976 \pm 7$ Ma, o que o relaciona temporalmente ao magmatismo da Suíte Intrusiva Creporizão, embora seus padrões geoquímicos sugiram assinatura calcioalcalina mais primitiva que a dessa unidade.

Apesar de apresentar semelhanças geoquímicas com o Complexo Cuiú-Cuiú, a idade de cristalização de $1918 \pm 9$ Ma do biotita monzogranito é correlata à Suíte Intrusiva Tropas, embora haja diferenças nos padrões geoquímicos.

A idade de cristalização (U-Pb SHRIMP) de $1978 \pm$ 6 Ma obtida para o muscovita monzogranito relaciona-o temporalmente à Suíte Intrusiva Creporizão, embora seus padrões geoquímicos assemelhem-se mais aos da Suíte Intrusiva Maloquinha, e a ocorrência de granitos com muscovita ainda não tenha sido descrita em nenhuma dessas unidades.
O sienogranito não foi datado, mas apresentou padrão de ETR sugestivo de afinidade alcalina e similaridades geoquímicas com a Suíte Intrusiva Maloquinha.

O fato de as rochas metassedimentares da Formação Castelo dos Sonhos terem sido intrudidas pelo dacito porfirítico (2011 \pm 6 Ma) e pelo biotita granodiorito (1976 $\pm 7 \mathrm{Ma}$ ), que revelaram idades de cristalização compatíveis com as de algumas unidades do Domínio Tapajós, sugere relação estratigráfica da Formação Castelo dos Sonhos com - Domínio Tapajós e também representa um dado adicional favorável à expansão do limite leste deste domínio.

O fato de não ser possível estabelecer conjuntamente relação temporal e geoquímica direta entre as rochas estudadas e as unidades litoestratigráficas do Domínio Tapajós discutidas pode indicar a existência de eventos magmáticos ainda não cartografados na região. Investigações mais detalhadas sobre os episódios magmáticos aqui identificados ainda se fazem necessárias.

A idade de $2011 \pm 6$ Ma é aqui apresentada como a idade mínima de sedimentação da Formação Castelo dos Sonhos, correspondendo também à idade mínima da mineralização aurífera singenética nela hospedada.

\section{AGRADECIMENTOS}

JDSQ agradece à Coordenação de Aperfeiçoamento de Pessoal de Nível Superior (CAPES), pela concessão de bolsa de estudos. ELK agradece ao Conselho Nacional de Desenvolvimento Científico e Tecnológico (CNPq), por concessão de bolsa de produtividade e pesquisa (processo 307443/2013-2). Os autores agradecem à TriStar Gold Inc., pela disponibilização do material estudado. Os autores agradecem ainda as valiosas contribuições do Dr. Amarildo Salina Ruiz e do revisor anônimo do Boletim do Museu Paraense Emílio Goeldi. Ciências Naturais. Este artigo é uma contribuição ao projeto "Evolução crustal e metalogenética em terrenos pré-cambrianos da Amazônia - segmentos noroeste do Cinturão Gurupi e sudeste do Domínio Tapajós" e ao Instituto Nacional de Ciência e Tecnologia da Amazônia (GEOCIAM). 


\section{REFERÊNCIAS}

ALKMIM, F. F., 2011. Stratigraphy and structure of the Castelo dos Sonhos gold mineralization host rocks, southern Pará, Brazil: 1-15. Internal Technical Report. Tristar Gold Inc., Houston.

AMARAL, G., 1974. Geologia pré-cambriana da região amazônica. Tese (Doutorado em Geociências) - Universidade de São Paulo, São Paulo.

BARRETO, C. J. S., J. M. LAFON, L. T. ROSA-COSTA \& E. F. LIMA, 2013. Vulcanismo félsico Paleoproterozoico do Grupo Iricoumé, noroeste do Pará, Domínio Erepecuru-Trombetas, Província Amazônia Central: dados de campo, caracterização petrográfica e geocronológica Pb-Pb em zircão. Geologia USP, Série Científica 13(1): 47-72.

BLACK, L. P., S. L. KAMO, C. M. ALLEN, D. W. DAVIS, J. N. ALEINIKOFF, J. W. VALLEY, R. MUNDIL, I. H. CAMPBELL, R. J. KORSCH, I. S. WILLIAMS \& C. FOUDOULIS, 2004. Improved $206 \mathrm{~Pb} / 238 \mathrm{U}$ microprobe geochronology by the monitoring of a trace-element related matrix effect: SHRIMP, ID-TIMS, ELAICP-MS and oxygen isotope documentation for aseries of zircon standards. Chemical Geology 205(1-2): 115-140.

BOYNTON, W. V., 1984. Cosmochemistry of the rare-earth elements: meteorite studies. In: P. HENDERSON (Ed.): Rare-earth elements geochemistry: 63-114. Elsevier, Amsterdam.

BRITO NEVES, B. B., J. M. SÁ, A. A. NILSON \& N. F. BOTELHO, 1995. A Tafrogênese Estateriana nos blocos paleoproterozoicos da América do Sul e processos subsequentes. Geonomos 3(2): 1-21.

COUTINHO, M. G. N., E. C. SOUZA, M. T. GUIMARÃES, T. LIVERTON \& J. N. WALSH, 2008. Petrologia e geoquímica das rochas hospedeiras. In: M. G. N. COUTINHO (Ed.): Província mineral do Tapajós: geologia, metalogenia e mapa previsional para ouro em SIG: 137-196. CPRM - Serviço Geológico do Brasil, Rio de Janeiro.

DALL'AGNOL, R., C. M. G. SILVA \& T. SCHELLER, 1999. Fayalitehedenbergite rhyolites of Iriri Formation, Tapajós Gold Province, Amazonian Craton: implication for the Uatumã volcanism. Boletim de Resumos do Simpósio sobre Vulcanismo e Ambientes Associados 1: 31.

FERNANDES, C. M. D., C. JULIANI, L. V. S. MONTEIRO, B. LAGLER \& C. M. ECHEVERRI-MISAS, 2011. High-K calc-alkaline to A-type fissure-controlled volcano-plutonism of the São Félix do Xingu region, Amazonian craton, Brazil: exclusively crustal sources or only mixed $\mathrm{Nd}$ model ages? Journal of South American Earth Sciences 32(4): 351-368.

FERREIRA, A. L., 2000. Formação Bom Jardim. In: M. E. ALMEIDA, M. E. SOARES, M. F. L. BRITO, A. L. FERREIRA \& M. A. S. MONTEIRO (Orgs.): Geologia e recursos minerais da Folha Vila Mamãe Anã (SB.21-V-D): estados do Pará e Amazonas. Escala 1:250.000. CPRM - Serviço Geológico do Brasil (Projeto Especial Província Mineral do Tapajós), Brasília. 1 CD-ROM.
FERREIRA, A. L., G. J. RIZZOTTO, M. L. E. S. QUADROS, R. B. C. BAHIA \& M. A. OLIVEIRA, 2004. Folha SB.21-Tapajós. In: C. SCHOBBENHAUS, J. H. GONÇALVES, J. O. S. SANTOS, M. B. ABRAM, R. LEÃO NETO, G. M. M. MATOS, R. M. VIDOTTI, M. A. B. RAMOS \& J. D. A. JESUS (Eds.): Carta Geológica do Brasil ao Milionésimo, Sistemas de Informações Geográficas - SIG. CPRM - Serviço Geológico do Brasil (Programa Geologia do Brasil), Brasília. 1CD-ROM.

GUIMARÃES, S. B., E. L. KLEIN, C. L. CHAVES, S. M. SOUZA, J. M. R. CASTRO, J. D. S. QUEIROZ, J. V. B. FEIO \& R. G. C. LIMA, 2015. Metalogenia das Províncias Minerais do Brasil: área sudeste do Tapajós, Estado do Pará: 1-49. CPRM (Informe Mineral, Série Províncias Minerais do Brasil, n. 5), Brasília.

JACKSON, S. E., N. J. PEARSON, W. L. GRIFFIN \& E. A. BELOUSOVA, 2004. The application of laser ablation-inductively coupled plasma-mass spectrometry to in situ $\mathrm{U}-\mathrm{Pb}$ zircon geochronology. Chemical Geology 211(1-2): 47-69.

JANOUSEK, V., C. M. FARROW \& V. ERBAN, 2006. Interpretation of whole-rock geochemical data in igneous geochemistry: introducing Geochemical Data Toolkit (GCDkit). Journal of Petrology 47(6): 1255-1259.

JULIANI, C., C. C. CARNEIRO, S. A. CARREIRO-ARAÚJO, C. M. D. FERNANDES, L. V. S. MONTEIRO \& A. P. CRÓSTA, 2013. Estruturação dos arcos magmáticos paleoproterozoicos na porção sul do Cráton Amazônico: implicações geotectônicas e metalogenéticas. Anais do Simpósio de Geologia da Amazônia 13: 157-160.

KLEIN, E. L., M. E. ALMEIDA \& L. T. ROSA-COSTA, 2012. The 1.891.87 Ga Uatumã Silicic Large Igneous Province, northern South America. Large Igneous Provinces Commission. Disponível em: <http:// www.largeigneousprovinces.org >. Acesso em: 23 janeiro 2014.

KLEIN, E. L., S. B. GUIMARÃES, C. L. CHAVES, J. B. RODRIGUES \& J. D. S. QUEIROZ, 2014. U-Pb (LA-ICP-MS) geochronology of detrital zircons from the Novo Progresso and Castelo dos Sonhos sedimentary formations: a preliminary approach to the source areas and implications for province boundaries in the Amazonian Craton. Program and Abstracts of the South American Symposium on Isotope Geology 9: 203.

LAMARÃO, C. N., R. DALL'AGNOL, J. M. LAFON \& E. F. LIMA, 2002. Geology, geochemistry and Pb-Pb zircon geochronology of the Paleoproterozoic magmatism of Vila Riozinho, Tapajós Gold Province Amazonian Craton, Brazil. Precambrian Research 119(14): 189-223.

LAMARÃO, C. N., R. DALL'AGNOL \& M. M. PIMENTEL, 2005. $\mathrm{Nd}$ isotopic composition of Paleoproterozoic volcanic rocks of Vila Riozinho: implications for the crustal evolution of the Tapajós gold province, Amazon Craton. Journal of South American Earth Sciences 18(3-4): 277-292.

LUDWIG, K. R., 2003. User's manual for Isoplot/Ex version 3.00 - ageochronology toolkit for Microsoft Excel: 1-70. Geochronological Center (Special Publication 4), Berkeley.

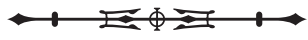


MACAMBIRA, E. M. B. \&A. G. VALE, 1997. São Félix do Xingu, folha SB.22-Y-B, Estado do Pará: Parte II: 29-93. Departamento Nacional da Produção Mineral (DNPM)/Serviço Geológico do Brasil (CPRM) (Programa Levantamentos Geológicos Básicos do Brasil), Brasília.

MOURA, C. A. V., P. S. S. GORAYEB \& N. S. MATSUDA, 1999. Geocronologia Pb-Pb em zircão do riolito Vila Raiol, Formação Iriri - sudoeste do Pará. Resumos Expandidos do Simpósio de Geologia da Amazônia 6: 475-477.

PEARCE, J. A., N. B. W. HARRIS \& A. G. TINDLE, 1984. Trace elements discrimination diagrams for the tectonics interpretation of granitic rocks. Journal of Petrology 25: 956-983.

PESSOA, M. R., A. F. SANTIAGO, A. F. ANDRADE, E. L. BARRETO, J. O. NASCIMENTO, J. O. S. SANTOS, J. R. OLIVEIRA, R. C. LOPES \& W. V. PRAZERES, 1977. Projeto Jamanxim - relatório final: 3 v.: 1-614. CPRM - Serviço Geológico do Brasil/DNPM - Departamento Nacional da Produção Mineral, Manaus.

QUEIROZ, J. D. S., 2015. Aspectos geológicos e metalogenéticos do depósito de ouro hospedado em metaconglomerados e metarenitos paleoproterozoicos Castelo de Sonhos, Província Tapajós, Sudoeste do Pará: 1-135. Dissertação (Mestrado em Geologia e Geoquímica) - Universidade Federal do Pará, Belém.

SANTOS, J. O. S., 2003. Geotectônica do Escudo das Guianas e BrasilCentral. In: L. A. BIZZI, C. SCHOBBENHAUS, R. M. VIDOTTI \& J. H. GONÇALVES (Eds.): Geologia, tectônica e recursos minerais do Brasil: 169-226. Serviço Geológico do Brasil, Brasília.

SANTOS, J. O. S., L. A. HARTMANN, H. E. GAUDETTE, D. I. GROVES, N. J. MCNAUGHTON \& I. R. FLECHER, 2000. New understanding of the Amazon Craton provinces, based on field work and radiogenic isotope data. Gondwana Research 3(4): 453-488.

SANTOS, J. O. S., D. I. GROVES, L. A. HARTMANN, M. A. MOURA \& N. J. MCNAUGHTON, 2001. Gold deposits of the Tapajós and Alta Floresta Domains, Tapajós-Parima orogenic belt, Amazon Craton, Brazil. Mineralium Deposita 36(3): 279-299.

SANTOS, J. O. S., L. A. HARTMANN, N. J. MCNAUGHTON \& I. R. FLETCHER, 2002. Timing of mafic magmatism in the Tapajós Province (Brazil) and implication for the evolution of the Amazon Craton: evidence from baddeleyite and zircon U-Pb SHRIMP geochronology. Journal of South American Earth Sciences 15(4): 409-429.

SANTOS, J. O. S., O. T. VAN BREEMEN, D. I. GROVES, L. A. HARTMANN, M. E. ALMEIDA, N. J. MCNAUGHTON \& I. R. FLETCHER, 2004. Timing and evolution of multiple Paleoproterozoic magmatic arcs in the Tapajós Domain, Amazon Craton: constraints from SHRIMP and TIMS zircon, baddeleyite and titanite $\mathrm{U}-\mathrm{Pb}$ geochronology. Precambrian Research 131(1-2): 73-109.

SEMBLANO, F. R. D., M. J. B. MACAMBIRA, N. C. S. PEREIRA \& M. L. VASQUEZ, 2014. New isotope data from Iriri-Xingu Domain, Central Amazonian Province: implications for Iriri Group age. Resumos do South American Symposium on Isotope Geology 9: 111.
SHAND, S. J., 1943. Eruptive rocks. Their genesis, composition, classification, and their relation to ore-deposits with a chapter on meteorite: 1-488. John Wiley \& Sons, New York.

SUN, S. S. \& W. F. MCDONOUGH, 1989. Chemical and isotopic systematics of oceanic basalts: implications for mantle compositions and processes. In: A. D. SAUNDERS \& M. J. NORRY (Eds.): Magmatism in ocean basins: 313-345. Geological Society (Special Publications), London.

TASSINARI, C. C. G. \& M. J. B. MACAMBIRA, 1999. Geochronological provinces of the Amazonian Craton. Episodes 22(3): 174-182.

TASSINARI, C. C. G. \& M. J. B. MACAMBIRA, 2004. A evolução tectônica do Cráton Amazônico. In: V. M. NETO, A. BARTORELLI, C. CARNEIRO \& B. BRITO-NEVES (Eds.): Geologia do continente sul-americano: evolução da obra de Fernando Flávio Marques de Almeida: 471-485. Beca, São Paulo.

TEIXEIRA, N. P., C. M. D. FERNANDES, C. A. V. MOURA \& S. C. C. PINHO, 2002. Geologia, geoquímica, geocronologia e isótopos de Sm-Nd de rochas vulcânicas paleoproterozoicas do Grupo Uatumã ocorrentes na região de São Félix do Xingu, Província Mineral de Carajás, Cráton Amazônico, Brasil. Anais do Simpósio de Vulcanismo e Ambientes Associados 2: 28.

TOKASHIKI, C. C., C. JULIANI, L. V. S. MONTEIRO, C. M. ECHEVERRI-MISAS, M. A. AGUJA \& L. B. ARRAIS, 2014. Mineralizações auríferas associadas a eventos vulcânicos de 1,97 Ga de sistemas epitermais Low-eintermediate-sulfidation no depósito Coringa - Província Mineral do Tapajós. Anais do Congresso Brasileiro de Geologia 47: 235.

VASQUEZ, M. L., 2006. Geocronologia em zircão, monazita e granada e isótopos de $\mathrm{Nd}$ das associações litológicas da porção oeste do Domínio Bacajá: evolução crustaldaporção meridional da província Maroni-Itacaiúnas, sudeste do Cráton Amazônico: 1-212. Tese (Doutorado em Geoquímica e Petrologia) - Universidade Federal do Pará, Belém.

VASQUEZ, M. L., E. L. KLEIN, M. L. E. S. QUADROS, R. B. C. BAHIA, A. SANTOS, P. S. F. RICCI, C. R. SACHETT, C. M. G. SILVA \& M. J. B. MACAMBIRA, 1999. Magmatismo Uatumã na Província Tapajós: novos dados geocronológicos. Resumos Expandidos do Simpósio de Geologia da Amazônia 6: 471-474.

VASQUEZ, M. L., E. L. KLEIN, M. J. B. MACAMBIRA, A. SANTOS, R. B. C. BAHIA, P. S. F. RICCI \& M. L. E. S. QUADROS, 2000a. Geochronology of granitoids, mafic intrusions and mineralizations of the Tapajós Gold Province, Amazonian Craton, Brazil. Abstracts of the International Geology Congress 31: 1 CR-ROM.

VASQUEZ, M. L., P. S. F. RICCI, E. L. KLEIN, A. SANTOS \& R. C. MARTINS, 2000b. Descrição das unidades litoestratigráficas e litodêmicas. In: M. L. VASQUEZ \& E. L. KLEIN (Orgs.): Geologia e recursos minerais da Folha Rio Novo (SB.21-Z-C), Estado do Pará, Escala 1: 250.000. CPRM - Serviço Geológico do Brasil (Projeto Especial Província Mineral do Tapajós), Brasília. 1 CD-ROM.

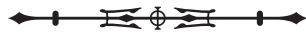


VASQUEZ, M. L., P. S. F. RICCI, E. L. KLEIN, A. SANTOS \& R. C. MARTINS, 2000c. Descrição das unidades litoestratigráficas e litodêmicas. In: E. L. KLEIN \& M. L. VASQUEZ (Orgs.): Geologia e recursos minerais da Folha Vila Riozinho (SB.21-Z-A), Estado do Pará, Escala 1:250.000. CPRM - Serviço Geológico do Brasil (Projeto Especial Província Mineral do Tapajós), Belém. 1 CD-ROM.

VASQUEZ, M. L. \& P. S. F. RICCI, 2002. Caracterização dos lamprófiros da Província Tapajós. Boletim de Resumos do Simpósio sobre Vulcanismo e Ambientes Associados 2: 91.

VASQUEZ, M. L., E. L. KLEIN \& P. RICCI, 2002. Granitoides pós-colisionais da porção leste da Província Tapajós. In: E. L. KLEIN, M. L. VASQUEZ \& L. T. ROSA-COSTA (Eds.): Contribuições à geologia da Amazônia: 3: 67-84. SBG-Núcleo Norte, Belém.

VASQUEZ, M. L., L. T. ROSA-COSTA, C. M. G. SILVA \& E. L. KLEIN, 2008a. Compartimentação tectônica. In: M. L. VASQUEZ \& L. T. ROSA-COSTA (Eds.): Geologia e recursos minerais do Estado do Pará: Sistema de Informações Geográficas e SIG: texto explicativo dos mapas geológico e tectônico e de recursos minerais do Estado do Pará. Escala 1:1.000.000. CPRM - Serviço Geológico do Brasil, Belém. 1 CD-ROM.

VASQUEZ, M. L., L. T. ROSA-COSTA, C. M. G. SILVA, P. S. F. RICCI, J. P. O. BARBOSA, E. L. KLEIN, E. C. S. LOPES, E. M. B. MACAMBIRA, C. L. CHAVES, J. M. A. CARVALHO, J. G. F. OLIVEIRA, G. C. ANJOS \& H. R. SILVA, 2008b. Unidades litoestratigráficas. In: M. L. VASQUEZ \& L. T. ROSA-COSTA (Eds.): Geologia e recursos minerais do Estado do Pará: Sistema de Informações Geográficas e SIG: texto explicativo dos mapas geológico e tectônico e de recursos minerais do Estado do Pará. Escala 1:1.000.000. CPRM - Serviço Geológico do Brasil, Belém. 1 CD-ROM.
VASQUEZ, M. L., C. L. CHAVES, E. M. MOURA, J. K. M. OLIVEIRA \& J. M. LAFON, 2013. Eventos magmáticos de 2020 - 1980 Ma nas folhas São Domingos e Jardim do Ouro, porção leste do Domínio Tapajós. Anais do Simpósio de Geologia da Amazônia 13: 209-212.

VASQUEZ, M. L., C. L. ChAVES, E. M. MOURA, J. K. M. OLIVEIRA \& J. M. LAFON, 2014a. Identificação das fontes das rochas de 2020 - 2010 Ma do leste do Domínio Tapajós com base nos isótopos de $\mathrm{Sm}-\mathrm{Nd}$. Anais do Congresso Brasileiro de Geologia 47: 1619.

VASQUEZ, M. L., C. L. CHAVES, E. M. MOURA \& J. K. M. OLIVEIRA, 2014b. Programa geologia do Brasil Jardim do Ouro, Folha SB.21-Z-A-III, Carta Geológica, Escala 1:100.000. CPRM, Belém.

WILLIAMS, I. S., 1998. U-Th-Pb geochronology by ion microprobe. In: M. A. MCKIBBEN, W. C. SHANKS III \& W. I. RYDLEY (Eds.): Applications of microanalytical techniques to understanding mineralizing processes: 7: 1-35. Society of Economic Geologists (EconomicGeology), Littleton.

YOKOI, Y. O., A. L. A. M. OLIVEIRA \& J. TACHIBANA, 2001. General economic geology of the High Tapajós Basin (The "Cachimbo" Gráben) and its boundaries: a regional geological survey with exploratory purpose. Resumos Expandidos do Simpósio de Geologia da Amazônia 7: 1 CD-ROM. 